\title{
Milletlerarası Ticari Tahkimde Hibrit Tahkim Klozlarının Geçerliliği ${ }^{*}$
}

\section{Validity of Hybrid Arbitration Clauses in International Commercial}

Arbitration

\author{
Ebru Şensöz Malkoç ${ }^{* *}$ (D), Müge Değirmencioğlu ${ }^{* * *}$ (iD
}

\section{öz}

Tarafların aralarında doğacak uyuşmazlığın belirleyecekleri kişi veya kişiler tarafından çözümlenmesi konusunda anlaşmaya vardıkları tahkim anlaşmaları, taraf iradelerinde bir sakatlık olmasa dahi, tahkim anlaşmasındaki hata veya çelişkiler nedeniyle geçersiz hale gelebilir. Tarafların birden fazla uyuşmazlık çözüm yolu ile tahkimi ya da mahkemeler ile tahkimi birlikte yetkilendirdiği veya bir tahkim merkezi ile başka bir tahkim merkezinin kurallarını birlikte yetkilendirdiği iki farklı unsuru sentezleyerek oluşturdukları hibrit tahkim anlaşmalarının geçerliliği sorunu da içerdiği çelişkiler nedeniyle ortaya çıkabilir. Çalışmamızda hibrit tahkim anlaşmalarının türleri ile birlikte bu türden tahkim anlaşmalarına uygulanacak hukuk ve geçerlilikleri incelenecektir. Özellikle bir tahkim merkezi bünyesinde başka bir tahkim merkezinin kurallarının uygulanmasının kararlaştırıldığı hibrit tahkim anlaşmalarının Türk tahkim hukuku açısından geçerliliği değerlendirilecektir.

Anahtar Kelimeler: Tahkim Anlaşmasının Geçerliliği, Patolojik Tahkim, Kusurlu Tahkim, Kademeli Tahkim Anlaşmaları, Med-Arb, Arb-Med, Medola, Arb-Med-Arb, Arb-Med-Opt-Out, Hibrit Tahkim Anlaşmaları

\section{ABSTRACT}

Arbitration agreements, in which the parties agree to settle their dispute between them by the person or persons they will determine, even if there is no injury in the will of the party, may be invalid due to errors or contradictions in the arbitration agreement. The validity of hybrid arbitration agreements, which are formed by synthesizing two different elements; like the parties authorize arbitration through more than one dispute resolution, or the courts and arbitration together or choose different arbitration institution for administering and rules, may be invalid too. In our study, the types of hybrid arbitration agreements will be analyzing and summarizing and then the applicable law to these arbitration agreements and the validity of these type of arbitration agreements will be examined. Most especially, the arbitration agreements' validity which applies the rules of one arbitral institution but which is administered by a different institution, which has not yet been raised before Turkish courts, will be examined under the Turkish law.

Keywords: Validity of Arbitration Agreements, Pathological Arbitration, Defective Arbitration, MultiTier Dispute Resolution, Combined Processes, Hybrid Prosses, Med-Arb, Arb-Med, Medola, Arb-MedArb, Arb-Med-Opt-Out, Hybrid Arbitration

\footnotetext{
* İ̀stanbul Ticaret Üniversitesi, Sosyal Bilimler Enstitüsü, Özel Hukuk Yüksek Lisans Programında 2020-2021 Güz Döneminde ilk yazar danışmanlığında savunulacak olan "Milletlerarası Ticari Tahkimde Patolojik Tahkim Anlaşmaları ve Hibrit Tahkim Klozları” başlıklı yüksek lisans tez çalışmasının bir ürünüdür.

** Doç.Dr., İstanbul Ticaret Üniversitesi Hukuk Fakültesi Milletlerarası Özel Hukuk Anabilim Dalı

*** İstanbul Ticaret Üniversitesi Sosyal Bilimler Enstitüsü Özel Hukuk Yüksek Lisans Programı Öğrencisi, mugedegirmencioglu@gmail.com, Sorumlu Yazar/Correspondence Author: Ebru Şensöz Malkoç
}

E-posta/E-mail: esensoz@ticaret.edu.tr

Geliş Tarihi/Received: $\quad$ 12.01.2021 


\section{Giriş}

Tahkim, devlet yargılamasına alternatif özel bir yargılama biçimidir. Yapılan yargılama neticesinde nihai bir karara varılması ve varılan bu kararın bağlayıcı nitelikte olması nedeniyle, tahkim yargılamasının diğer alternatif uyuşmazlık çözüm yöntemlerinden ayrıldığı kabul edilmektedir.

Tahkim anlaşmaları, irade sakatlıkları barındırması, anlaşmada hata veya çelişki bulunması gibi nedenlerle kusurlu duruma gelebilir. Tahkim anlaşmasının kusurlu olması, literatürde tahkim anlaşmasının patolojik olduğu şeklinde ifade edilmektedir. Belirtmek gerekir ki, her patolojik tahkim anlaşması geçersiz değildir. Tahkim anlaşmasının patolojik olduğu yargılamaların farklı aşamalarında ve farklı makamlar önünde ileri sürülebilir. Birden fazla unsurun sentezlenmesi nedeniyle hibrit olarak ifade edilen tahkim anlaşmaları da, geçerliliklerinin tartışmalı olması nedeniyle, patolojik tahkim anlaşmaları içinde değerlendirilmektedir.

Çalışmamızda, öncelikle tahkim anlaşmalarının geçersizliğinin hangi makamlar önünde, hangi aşamalarda ileri sürülebileceği incelenecek, ardından tahkim anlaşmalarının geçersizliğine uygulanacak hukuk tespit edilecektir. İkinci bölümde, patolojik tahkim anlaşmalarının çerçevesi belirlendikten sonra, özellikle hibrit tahkim anlaşmaları incelenecektir. Hibrit tahkim anlaşmaları, çalışmamız kapsamında; (1) tahkim ile birlikte başkaca alternatif uyuşmazlık çözüm yöntemlerinin sentezlendiği ya da tahkim ile birlikte mahkemelerin öncelik sonralık ilişkisi ile yetkilendirildiği anlaşmalar ve (2) kurumsal bir tahkim merkezinin bir başka kurumsal tahkim merkezinin kurallarını uygulamak şartı ile yetkilendirildiği anlaşmalar olarak iki ayrı başlık altında ele alınacaktır.

Birden fazla uyuşmazlık çözüm yönteminin sentezlendiği hibrit tahkim anlaşmalarının birçok görünüş biçimi olmasına karşın, bu türden anlaşmalar sıklıkla, tarafların önce arabuluculuk sonra tahkim öngördüğ̈ med-arb, tarafların aralarında yalnızca bir tahkim anlaşması bulunan hallerde arabuluculuğa gitmeyi kararlaştırmaları ile fiili olarak oluşacak arb-med-arb, tarafların arabuluculuk ve tahkimi birlikte öngördükleri ancak hakemlerin yetkisini yalnızca kendi önerileri ile sınırlandırdığı medola ya da tarafların tahkim anlaşmasında hakemler henüz kararını açıklamadan önce son bir şans olarak arabulucuya gitmelerini öngören arb-med olarak karşımıza çıkabilmektedir. Bu tür tahkim anlaşmalarının geçerliliği ve tahkim öncesi aşamalar tüketilmeden tahkim yargılamasına başvurulup başvurulamayacağı çalışmamızda değerlendirilecektir.

Hibrit tahkim anlaşması niteliğinde olması nedeniyle, devlet mahkemelerinin kademeli olarak öncelik-sonralıkilişkisi içinde tahkim mahkemeleri ile birlikte yetkilendirildiği tahkim anlaşmalarının geçersizliği konusu da çalışmamız kapsamında incelenecektir. Ancak, tahkim yargılaması ile birlikte bir öncelik-sonrası ilişkisi barındırmadan devlet mahkemelerini yetkilendiren tahkim anlaşmaları, hibrit özellik göstermemeleri nedeniyle çalışmamız kapsamında ele alınmamıştır. Zira hibrit kavramı bir "sentezleme" ifade ederken, tahkim ve devlet mahkemelerinin birlikte yetkilendirildiği ya da "veya" ibaresi ile alternatifli olarak yetkilendirildiği tahkim anlaşmaları, bir iş bölümü ve sentez içermemektedir. 
Bir kurumsal tahkim merkezinin bir başka kurumsal tahkim merkezinin kurallarını uygulamak şartıyla yetkilendirildiği hibrit tahkim anlaşmalarının geçerliliği de tartışma yaratmaktadır. $\mathrm{Bu}$ türden hibrit tahkim anlaşmalarının, 'tahkim kurumu kurallarının, yalnızca onu hazırlayan tahkim kurumuna uygun olacağı’ gerekçesiyle geçersiz olacağı ifade edilmektedir. Bu nedenle, üçüncü bölüm altında, bir kurumsal tahkim merkezinin bir başka kurumsal tahkim merkezinin kurallarını uygulamak şartıyla yetkilendirildiği hibrit tahkim anlaşmalarının geçerliliğine ilişkin olarak verilmiş mukayeseli hukukta yer alan yargı kararları incelenecek ve yapacağımız tespitler çerçevesinde, bu türden hibrit tahkim anlaşmalarının genel olarak ve Türk hukuku bakımından geçerliliği üzerine bir değerlendirme yapılacaktır.

\section{TAHKIM ANLAŞMASININ GEÇERSIZLIĞi VE PATOLOJIK TAHKIM ANLAŞMALARI}

Tahkim, devlet yargısına alternatif özel bir yargılama biçimidir. Taraflar aralarında yaptıkları geçerli bir tahkim anlaşması ile bu anlaşmada gösterdikleri belirli bir hukuki ilişkiden doğmuş ya da doğacak uyuşmazlıkların tamamının veya bir kısmının çözümü için tahkim mahkemesini yetkili hale getirirler. Ancak, taraflar arasındaki tahkim anlaşması, kimi zaman iradelerindeki muğlaklık, kimi zamansa, tahkim anlaşmasındaki hatalar veya çelişkiler nedeniyle kusurlu, başka bir ifadeyle patolojik hale gelebilir. İfade etmek gerekir ki, her patolojik tahkim anlaşması geçersiz değildir ${ }^{1}$. Ancak, her geçersiz tahkim anlaşması, patolojik bir tahkim anlaşmasıdır.

Bir tahkim anlaşmasının geçerliliğine ilişkin itiraz, devlet mahkemelerinde ileri sürülebileceği gibi, kompetenz-kompetenz (competence-competence) prensibi gereğince, hakem mahkemeleri önünde de ileri sürülebilir.

Yine, tahkim anlaşmasının geçersizliği itirazı, hakem kararı verilmeden önce ileri sürülebileceği gibi; karar verildikten sonra da ileri sürülebilir ${ }^{2}$. Ancak belirtmek gerekir ki, karar verildikten sonra tahkim anlaşmasının ilk kez ileri sürülmesinin dürüstlük kuralına aykırı olduğu ifade edilmektedir³

Sonuç olarak, tahkim anlaşmasının geçersizliği itirazı; (1) hakem heyeti önünde, (2) mahkeme önünde bir davada tahkim itirazına karşı, (3) mahkeme önünde iptal davası aşamasında, (4) yabancı bir hakem kararı mevcut ise, mahkeme önünde tenfiz davası aşamasında ileri sürülebilir .

1 Duarte G Henriques, 'Pathological Arbitration Clauses, Good Faith and The Protection of Legitimate Expectations' (2015) 31(2) Arbitration International 349, 353 naklen Frédéric Eisemann, 'La clause d’arbitrage pathologique" (1974) c.3 l'arbitrage international Essais in memoriam Eugenio Minoli, C. 3, Milano, 129.

2 Ece Selin Tekin, Milletlerarası Tahkim Hukukunda Tahkim Anlaşmasının Geçerliliğe Uygulanacak Hukuk (1st edn, On İki Levha 2019), 124.

3 Cemal Şanlı, Uluslararası Ticari Akitlerin Hazırlanması ve Uyuşmazlikların Çözüm Yolları (7th edn, Beta 2019) 427; Ziya Akıncı, Milletlerarası Tahkim (5th edn, Vedat 2020) 402-403; Sibel Özel, Milletlerarası Ticari Tahkimde Kanunlar İhtilafı Kuralları (1st edn, Legal 2008) 86; Fatih Aydemir, Türk Hukukunda Tahkim Sözleşmesi (1st edn, On İki Levha 2017) 388, 394; Esen Aydın, 'Milletlerarası Ticari Tahkimde Patolojik Tahkim Şartı ve Sözleşmesi' (LL.M. thesis, İstanbul Üniversitesi 2018) 55,59; Tekin (n 2) 167, 169.

4 Özel (n 3) 79; Hüseyin Af̧̧ın İlhan, Tahkim Sözleşmesinin Geçerliliği (1st edn, Adalet 2016) 30; Aydemir (n 3) 373; Aydın (n 3) 38; Tekin (n 2) 85,124. 


\section{A. TAHKIM ANLAŞMASININ GEÇERSIZLIĞININ ILERI SÜRÜLMESI}

\section{Tahkim Anlaşmasının Geçersizliğinin Hakem veya Hakem Heyeti Önünde İleri Sürülmesi}

Tahkim yargılamasında, en geç cevap dilekçesine kadar, davalının tahkim anlaşmasının geçersiz olduğuna ilişkin itirazı neticesinde, komptenz-kompetenz prensibi gereği, hakemler tahkim anlaşmasının geçerliliği konusunda, başka bir ifadeyle, kendi yetkileri konusunda karar verirler ${ }^{5}$. Nitekim, hakemlere sahip olduğu yetkileri veren de sinırlayan da tarafların akdettikleri tahkim anlaşmasıdır.

Tahkim anlaşması ile bir kurumsal tahkim merkezinin yetkilendirildiği durumlarda, henüz bir yargllama başlamadan da, tahkim kurumu bünyesinde prima facie bir incelemeyle tahkim anlaşmasının geçerliliğine karar verilebilirken ${ }^{6}$, ad hoc bir tahkim öngörülmüşse, ancak, tahkim mahkemesi kurulduktan sonra tahkim anlaşmasının geçerliliği değerlendirilebilecektir ${ }^{7}$. Kurumsal ya da ad hoc tahkim fark etmeksizin, tahkim yargılaması başladıktan sonra, tarafların tahkim anlaşmasının geçersizliğine ilişkin itirazları, hakemler tarafından bir ara karar ile sonuca bağlanır.

Tahkim anlaşmasının geçerliliğine uygulanacak hukuk konusunda genel bir kabul olmamakla birlikte $^{8}$, genellikle, taraflara, tahkim anlaşmasının geçerliliğine uygulanacak hukuku seçme imkânı

$5 \quad$ Aydemir (n 3) 378-380.

6 Aydın (n 3) 53; Banu Şit, Kurumsal Tahkim ve Hakem Kararlarının Tanınması ve Tenfizi (1st edn, İmaj 2005$) 48$.

$7 \quad$ Aydin (n 3) 53.

8 Doktrinde tahkim anlaşmasının hukuki niteliği konusunda bir görüş birliği olmamakla birlikte, dört farklı teori ortaya atılmıştır. Bu teorilerden ilki olan maddi hukuk görüşü, tahkim anlaşmasının bir borçlar hukuku sözleşmesi olması nedeniyle, uygulanacak hukukun taraf iradelerine tabii olduğunu savunur ( Bkz Erol Ertekin and İzzet Karataş, Uygulamada İhtiyari Tahkim ve Yabancı Hakem Kararlarının Tenfizi Tanınması (1st edn, Yetkin 1997) 419, 422-423; Özel (n 3) 32; İlhan (n 4) 9; Tekin (n 2) 21-23; Nazlı Töre, Milletlerarası Tahkimde Tahkim Anlaşmasının Varlığı Geçerliliği ve Etkileri (1st edn, Turhan 2019) 39-48; Begüm Gedik, Milletlerarası Tahkim Kararlarının İptal Edilme Nedenlerinden Tahkim Anlaşmasının Geçersiz Olması (1st edn, Seçkin 2020) 68-69; Gülgün Ildır, Alternatif Uyuşmazlık ÇözümüMedeni Yargıya Alternatif Yöntemler (1st edn, Seçkin 2003) 57-58). İkinci teori olan usul hukuku görüşü ise, yarg1 yetkisi kendinde olan devletin, tahkim anlaşması yapma yetkisini, taraflara usul kanunlarınca tanıdığını ve bu nedenle tahkim anlaşmasının bir usul hukuku sözleşmesi olduğunu savunur (bkz Ertekin and Karataş (n 8) 419, 423-424; Özel (n 3) 33; Illhan (n 4) 9 - 11; Tekin (n 2) 23-28; Töre (n 8) 48-55; Gedik (n 8) 70-71; Ildır (n 8) 58). Bu teoriye göre, tahkim yargılamasının da devlet yargısının bir parçası olması nedeniyle, hakem de hâkim gibi lex fori’yi uygular (Bkz Töre (n 8) 52). Üçüncü bir teori ise karma teoridir, karma teori tahkim anlaşmasının kurucu unsurlarının maddi hukuka yönelik, sonuçlarının ise usul hukukuna yönelik olduğunu ifade ederek; tahkim anlaşmasının maddi hukuk ve usul hukuku sözleşmelerinin birleşiminden oluştuğunu savunmaktadır ( Bkz Ertekin and Karataş (n 8) 419, 425; Özel (n 3) 33; İlhan (n 4) 11; Tekin (n 2) 28-30; Töre (n 8) 55-58; Gedik (n 8) 71-72; Ildır (n 8) 58). Son olarak bağımsız teori, milletlerarası tahkimin milli hukuklardan bağımsız ele alınması gerektiğini savunmaktadır ( Bkz Ertekin and Karataş (n 8) 419,425426; Özel (n 3) 33-35; İlhan (n 4) 12; Tekin (n 2) 30-34; Töre (n 8) 58-62; Gedik (n 8) 72-73).Bağımsız teoriyi savunanlar, tahkim yeri ile tahkimin bağını zayıflatarak, mahkemelerin, tahkim yargılaması üzerindeki rolünün de azalmasını amaçlamaktadır ( Bkz Ertekin and Karataş (n 8) 419,425-426; Özel (n 3) 33-35; İlhan (n 4) 12; Tekin (n 2) 30-34; Töre (n 8) 58-62; Gedik (n 8) 72-73). Tarafların tahkim anlaşmasının geçerliliğine uygulanmak üzere bir hukuk seçmiş olmaları durumunda, tahkim anlaşmasının geçerliliğine seçilen bu hukuk uygulanacaktır. Taraflarca böyle bir hukuk seçimi yapılmamış olması durumunda ise, farklı devlet hukuklarında farklı yaklaşımlar uygulandığı görülmektedir (Bkz Özel (n 3) 79). Taraflarca bir seçim yapılmadığı durumlarda tahkim anlaşmasının geçerliliğine bazı hukuklarda tahkim yeri hukuku uygulanırken (İsveç, Belçika, Hollanda ve İtalyan mahkemelerinin aynı yönde birçok kararı mevcuttur. Bkz Nigel Blackaby, Constantine Partasides, Alan Redfern and Martin Hunter, Redfern and Hunter on International Arbitration Student Version (6th edn, Oxford 2015) 162 ff; Milo Molfa, 'Pathological Arbitration Clauses and The Conflict of Laws' (2007) 37(1) Hong Kong Law Journal 161, 169) Ayrıca tahkim anlaşmasının geçerliliğine uygulanmak 
tanınmaktadır. Taraflarca bu yönde bir seçim yapıldığı durumda, hakemler, tahkim anlaşmasının geçerliliğini, tarafların seçtiği hukuka göre değerlendirir ${ }^{9}$. Tahkim anlaşmasının geçerliliğine uygulanacak hukuk konusunda bir hukuk seçimi yapılmamışsa, tahkim anlaşmasının geçerliliğine uygulanacak hukukun tespiti, farklı devlet hukuklarında farklı şekillerde düzenlenmiştir. Bazı hukuklarda tahkim anlaşmasının geçerliliği konusunda hukuk seçimi yapılmadığ durumlarda, tahkim anlaşmasının geçerliliğine tahkim yeri hukukunun uygulanacağı düzenlenmişken, bazı hukuklarda esas sözleşmeye uygulanacak hukukun, bazı hukuklarda, tahkim kurumunun kurallarının ya da genel hukuk prensiplerinin uygulanacağı, bazı hukuklarda ise, nadiren de olsa, tenfiz yeri hukukuna göre geçerliliğin değerlendirileceği kabul edilmektedir ${ }^{10}$.

Türk hukukunda, Milletlerarası Tahkim Kanunu ${ }^{11}$ (MTK)'nın uygulama alanına giren ${ }^{12}$ uyuşmazlıklarda; tahkim anlaşmasının geçerliliğine uygulanacak hukuk; MTK m. 4/f.3 “...Tahkim anlaşması, tarafların tahkim anlaşmasına uygulanmak üzere seçtiği hukuka veya böyle bir hukuk seçimi yoksa Türk hukukuna uygun olduğu takdirde geçerlidir” hükmü uyarına; taraflarca bir hukuk seçimi yapılmışsa bu hukuk, bir hukuk seçimi yoksa Türk hukukudur. Ancak, Türk hukukunda, MTK’nın uygulama alanına girmeyen uyuşmazlıklarda tahkim anlaşmasının geçerliliğine hangi hukukun

üzere tahkim yeri hukukunun uygulanmasının nedeni, en azından icra edilebilir bir karar ortaya çıkarmaktır. Bkz Tekin (n 2) 108-109), bazı hukuklarda esasa uygulanacak hukukun (bkz Özel (n 3) 84-85; Tekin (n 2) 94, 112, 114. Örneğin İngiliz Hukukunda tarafların esas sözleşmeye uygulanmak üzere bir hukuk seçmeleri durumunda, tahkim anlaşmasının geçerliliğine uygulanacak hukuk seçilmemişse, geçerliliğe de bu hukukun uygulanacağı karinesi kabul edilmektedir. Bkz Molfa (n 8)167; Hong Kong Mahkemeleri de İngiliz Mahkemelerinde olduğu gibi, tahkim anlaşmasının geçerliliğine esas sözleşmeye uygulanacak hukukun uygulanacağına ilişkin kararlar vermektedir. Bkz Molfa (n 8) 169. Beyond the Network Ltd $v$ Vectone Ltd [2005] HKEC 2075. Aynı yönde Amerikan Mahkemelerinde de tahkim anlaşmasının geçerliliğine uygulanmak üzere bir hukuk seçimi yapılmamışsa, esas sözleşmenin geçerliliğine uygulanacak hukuka göre değerlendirme yapılması yerleşmiş bir içtihattır. Bkz Molfa (n 8) 168 Ancak Birleşik Krallık yüksek krallık mahkemesi 09.09.2020 tarihli yeni bir kararında, kararın 170. Paragrafında; tahkimin anlaşmasının geçerliliğine uygulanacak hukuka ilişkin prensipleri yeniden değerlendirmiştir. Karara göre, esasa uygulanacak hukuk, kural olarak tahkim anlaşmasının geçerliliğine uygulanmamalıdır. Tahkim anlaşmasının geçerliliğine uygulanacak hukuk, taraflarca seçilen bir hukuk yoksa, tahkim anlaşması ile en sıkı ilişkili olan hukuk olmalıdır. Eğer taraflarca seçilen bir tahkim yeri varsa, bu hukuk en sıkı ilişkili hukuk olarak kabul edilir ancak, taraflarca tahkim yeri seçilmemişse, taraflarca esasa uygulanmak üzere seçilen hukuk en sıkı ilişkili hukuk olarak kabul edilmelidir. Bkz. https://www.bailii.org/uk/cases/UKSC/2020/38.html (Erişim tarihi: 12.12.2020). Bazı hukuklarda ise, uluslararası hukukun genel prensiplerinin (ancak genel kabul görmüş bir "uluslararası hukukun genel prensibi” kavramı olmaması nedeniyle, tahkim anlaşmasının geçerliliğine uluslararası hukukun genel prensipleri uygulaması yaygın şekilde gözlemlenmemektedir. Bkz Özel (n 3) 84; Tekin (n 2) 120) ve nadiren de olsa bazı hukuklarda tenfiz yeri hukukunun (Tenfiz yeri hukukunun yaygın olarak kullanılmamasının nedeni doktrinde; tenfiz yeri hukukunun önceden belli olmaması nedeniyle, bu hukuka göre değerlendirme yapılmasının hakemlerin önceden kanaat belirtmiș izlenimi yaratacağı olduğu ifade edilmektedir. Bkz Tekin (n 2) 97, 120, 121.) uygulandığı görülmektedir. Fransız Yüksek Mahkemesi ise, diğer hukuk sistemlerinden farklı olarak, (tahkim anlaşmasının Fransız Hukukunun emredici kurallarına ve milletlerarası kamu düzenine aykırı olması durumları hariç) tahkim anlaşmasının geçerliliğinin hiçbir hukuka atıf yapılmadan değerlendirileceğini kabul etmektedir ( Bkz Blackaby, Partasides, Redfern and Hunter (n 8)164; Aydın (n 3) 49; Tekin (n 2) 97).

9 Özel (n 3) 83; Aydın (n 3) 54; Tekin (n 2) 86, 88.

10 Özel (n 3 ) 84-85; Tekin (n 2) 93-94, 97, 120-121. Ayrıca tahkim anlaşmasının geçerliliğine uygulanacak hukuk hakkında bkz I. B. Tahkim Anlaşmasının Geçerliliğine Uygulanacak Hukuk.

11 Milletlerarası Tahkim Kanunu Kanun Numarası: 4686 Kabul Tarihi: 21/6/2001 RG 05.07.2001/ 24453.

12 MTK m.1 f.2 "Bu Kanun, yabancılık unsuru taşıyan ve tahkim yerinin Türkiye olarak belirlendiği veya bu Kanun hükümlerinin taraflar ya da hakem veya hakem kurulunca seçildiği uyuşmazlıklar hakkında uygulanır." 
uygulanacağı düzenlenmemiştir. Bu noktada kanunda bir boşluk bulunduğu ifade edilmektedir ${ }^{13}$. Gerekçeleri farklı olmakla birlikte, bazı görüşler MTK m. 4 f.3'ün kıyasen uygulanması ve tahkim anlaşmasının geçerliliğine Türk Hukuku’nun uygulanması gerektiğini savunurken ${ }^{14}$, bazı görüşler ise yine farklı gerekçeler sunmakla birlikte, tahkim yeri hukukunun uygulanması gerektiğgini ${ }^{15}$ savunmaktadır. MÖHUK m.62/f.1 hükmü ile Türkiye’nin taraf olduğu sözleşmelerin içerdiği hükümler (NYS m.V/1/a ve Avrupa Cenevre Sözleşmesi m. 6/f.2) dikkate alındığında, Türk hukukunda, MTK’nın uygulama alanına girmeyen uyuşmazlıklarda, tahkim anlaşmanın geçerliliğine kanaatimizce de tahkim yeri hukuku uygulanmalıdır. Ancak tahkim yargılaması henüz başlamamış ve tahkim anlaşmasının geçersizliği itirazı devlet mahkemesinde tahkim itirazı üzerine inceleniyorsa ve tahkim anlaşmasında tahkim yeri belli değilse, bu durumda tahkim anlaşmasını geçerliliğine uygulanacak hukuk noktasında yine bir belirsizlik doğacaktır. Bu durumda, MTK m. 5 hükmü çerçevesinde Türk mahkemesinde tahkim itirazı yapıldığında, MTK m. 4/f.3, mevcut kanun boşluğu nedeniyle kıyasen uygulanarak, taraflarca tahkim anlaşmasının geçerliliğine uygulanacak hukuk seçimi yapılmamış ise, Türk hukukuna göre tahkim anlaşmasının geçerli olup olmadığ 1 değerlendirilmelidir.

\section{Tahkim Anlaşmasının Geçersizliğinin Devlet Mahkemesi Önünde Tahkim Ilk İtirazına Karşı ileri Sürülmesi}

Taraflar arasında bir tahkim anlaşması bulunmasına karşın, taraflardan biri devlet mahkemeleri önünde dava açmışsa, diğer taraf tahkim 'ilk itirazı́nda bulunabilecektir. Türk hukukunda hem 4686 sayılı Milletlerarası Tahkim Kanunu m. 5 hem de 6100 sayılı Hukuk Muhakemeleri Kanunu ${ }^{16}$ (HMK) m. 413 hükümlerinde taraflar arasında bir tahkim anlaşması bulunması durumunda, devlet mahkemelerinde dava açılmışsa, davalıya tahkim itirazında bulunma hakkı tanınmaktadır ${ }^{17}$.

13 Şanlı ( n 3), 356-357.

14 MTK m.4 f.3'ün herhangi bir kıstas belirlemeden Türk hukukunu işaret etmesi nedeniyle Türk hukukunun uygulanması gerektiği yönünde bkz Özel (n 3) 81. Kanun boşluğunun kıyasen MTK m.4/f.3 uygulanarak doldurulması ve Türk hukuku uygulanması gerektiği yönünde bkz Cemal Şanlı, Emre Esen and İnci Ataman Figanmeşe, Milletlerarası Özel Hukuk (8th edn, Beta 2020) 692-693 dn. 586; (ancak ifade etmek gerekir ki, Esen, ikili bir ayrım yapmakta ve, tahkim ilk itirazı olduğu hallarde kıyasen uygulama gerektiği görüşünü savunmaktadır. Așağıda ayrıca ifade edileceği üzere, ikinci ihtimal olarak MTK’nın özel kanun, MÖHUK’un genel kanun olması nedeniyle, özel kanunda hüküm bulunmayan hallerde genel hükümlerinin uygulanması yoluyla çözülmesidir. Emre Esen, 'Yetkili Kılınan Tahkim Kurumunun Mevcut veya Belirli Olmadığı Tahkim Anlaşmalarının Geçerliliği' (2017) 2017(2)UTTDER 75, 94-96.

15 MÖHUK hükümlerince en sıkı ilişkili hukuk olması nedeniyle tahkim yeri hukukunun uygulanması gerektiği yönünde bkz Esen,'Mevcut veya Belirli' (n 14) 96-97; New York Sözleşmesi kapsamında tahkim anlaşmasının geçerliliğine tahkim yeri hukukunun uygulanması gerektiği yönünde bkz A. İpek Sarıöz Büyükalp, 'Uluslararası Tahkimde "Tahkim Anlaşmasının Hükümsüz, Tesirsiz veya İcrasının İmkânsız Olması” Kavramları' (2014), 16 (Özel Sayı) DEÜHFD in Prof. Dr. Hakan Pekcanıtez’e Armağan 2015, 2030; uyuşmazlı̆̆ın Cenevre Konvansiyonu kapsamına giren uyuşmazlıklar bakımından, Konvansiyon kapsamında taraflarca seçilen bir hukuk yoksa tahkim yeri hukukunun, eğer tahkim yeri hukuku da belirlenemiyorsa Türk hâkiminin kendi kanunlar ihtilafı kurallarının uygulanması gerektiği yönünde bkz Aydin (n 3) 47.

16 Hukuk Muhakemeleri Kanunu Kanun Numarasi: 6100 Kabul Tarihi: 12/1/2011 RG 04.02.2011/ 27836.

17 Hakan Pekcanıtez and Ali Yeşilırmak, Pekcanıtez Usul Medeni Usul Hukuku C III (15th edn, On İki Levha 2017) 2664; Vahit Doğan, Milletlerarası Özel Hukuk (5th edn, Savaş 2019) 158; Aysel Çelikel and Bahadır Erdem, Milletlerarası Özel Hukuk (15th edn, Beta 2017) 790; Ergin Nomer, Devletler Hususi Hukuku (22nd edn, Beta 2017) 584; Berk Demirkol, 
Tahkim ilk itirazı neticesinde, mahkemeler, geçerli bir tahkim anlaşmasının mevcut olup olmamasına göre bir değerlendirme yapacaktır. 1958 tarihli Yabancı Hakem Kararlarının Tanınması ve Tenfizi Hakkında New York Sözleşmesi ${ }^{18}$ (NYS) m. II/f. $3^{19}$ hükmü, tahkim itirazı neticesinde, mahkemenin, tahkim anlaşmasının 'hükümden düşmüş, tesirsiz veya tatbiki imkânsız' olup olmadığının değerlendirilmesi gerektiğini hükme bağlanmıştır. HMK m.413 hükmü de New York Sözleşmesi gibi, mahkemenin, tahkim itirazı üzerine yapacağı incelemede "tahkim anlaşmasının hükümsüz, tesirsiz, uygulanması imkânsız” olup olmadığını tespit edileceğini hükme bağlamıştır. MTK m.5, "tahkim itirazının kabulü halinde, mahkeme davayı usulden reddeder" hükmünü havi olup, tahkim itirazı üzerine mahkemece yapılacak incelemede, "tahkim anlaşmasının hükümsüz, tesirsiz, uygulanması imkânsız” olup olmadığının incelenmesine ilişkin bir ifade bulunmamaktadır. Bununla birlikte doktrinde, Balkar Bozkurt, mahkemenin tahkim itirazı üzerine yapacağı incelemede, "tahkim anlaşmasının hükümsüz, tesirsiz, uygulanması imkânsız" olup olmadığının tespit edilmesi gerektiğine ilişkin hükmün, böyle bir hüküm içermeyen MTK m.5 hükmünün uygulanmasında da dikkate alınması gerektiğini ifade etmektedir ${ }^{20}$. Ancak ne NYS'de ne de HMK'da yapılacak değerlendirmenin sınırları net bir şekilde çizilmemiştir. Mahkemenin yapacağı bu değerlendirmenin prima facie bir inceleme mi yoksa derinlemesine bir inceleme mi olacağı tartışmalıdır ${ }^{21}$.

Doktrin bu konuda genel olarak iki görüş üzerinde durmaktadır: bir görüş, mahkemenin prima facie bir inceleme ile geçerlilik değerlendirmesini hakemlere bırakması gerektiği yönündeyken ${ }^{22}$, diğer bir görüş ise, incelemenin derinlemesine yapılarak, tahkim anlaşmasının geçerliliğinin de mahkemece değerlendirilmesi gerektiği yönündedir ${ }^{23}$.

'Mutlak Olmayan Milletlerarası Tahkim Anlaşmalarının Geçerliliği' (2017) 16(2) GÜHFD 325, 345; Aydemir (n 3 ) 373 - 374; Aydın (n 3) 38.

18 Yabancı Hakem Kararlarının Tanınması ve Tenfizi Hakkında New York Sözleşmesi, Kanun Numarası: 3731, Kabul Tarihi:08.05.19911, R.G. 21.05.1991/20877.

19 NYS m. II f. 3 "Bir Âkit Devlet mahkemesi, tarafların, işbu maddenin anladı̆̆ı manada anlaşma akdettikleri bir konu ile ilgili uyuşmazhklarına el koyduğu takdirde, anlaşmanın hükümden düşmüş, tesirsiz veya tatbiki imkânsiz bir halde olduğunu tespit etmedikçe, bunları, birinin talebi üzerine, hakemliğe sevkeder."

20 Süheyla Balkar Bozkurt 'Milletlerarası Tahkimde Yargılama Masraflarının Hak Arama Özgürlüğüne Etkisi ve Sonuçları' (Mayıs-Haziran 2015), 10 (129-130) Bahçeşehir Üniversitesi Hukuk Fakültesi Dergisi, 121, 198, 202.

21 Akıncı, Milletlerarası Tahkim (n 3) 182-183; Bilgehan Yeşilova, 'Milletlerarası Tahkimin Hukuki Niteliği Üzerine Düşünceler ve Güncel Gelişmeler' (2008), 76 TBB 83, 123; Emre Esen, 'Uluslararası Tahkime Tâbi Bir Uyuşmazlığın Devlet Mahkemelerine Götürülmesi Halinde Tahkim Anlaşmasının Geçerliliğine İlişkin İtirazların İncelenmesi ve Kompetenz-Kompetenz Prensibi' (2011) 10(1) GSÜHFD in Prof. Dr. Ata Sakmar’a Armağan 355, 356; Cansu Yener Keskin, Milletlerarası Tahkim Anlaşmasının Kurulması ve Etkisi (1st edn, On İki Levha 2017) 241; Töre (n 8) 86; Aydın (n 3) 41; Hatice Özdemir Kocasakal, 'Yargitay 15.Hukuk Daire’sinin Bir Kararı Çerçevesinde Mahkemelere De Yetki Veren Tahkim Anlaşmalarının Geçerliliği ve Bu Geçerliliğin Tespitinin Mahkemeler Tarafından Yapılıp Yapılamayacağı’ (2017) On İki Levha Prof.Dr. Hamdi Yasaman’a Armağan, 509, 515.

22 Esen, 'kompetenz kompetenz' (n 21) 377, 380; Ali Yeşilırmak, 'Geçerli Bir Tahkim Anlaşmasının Varlığına Rağmen Genel Haciz Yoluyla Takip Yapılabilir mi?’ (2011) 96 TBB Dergisi 205, 208, 210; Mustafa Erkan, Milletlerarası Tahkimde Yetki Sorunları (1st edn, Yetkin 2013) s. 96; A. İpek Sarıöz Büyükalp, Milletlerarası Ticari Tahkimde Tahkim İtirazı ile Karşılaşan Türk Hâkiminin Tahkim Anlaşmasının Geçerliliğine Dair Yapacağı İncelemenin Kapsamı ve Sonuçları (Eylül Ekim 2014) 9 (121-122) Bahçeşehir Üniversitesi Hukuk Fakültesi Dergisi, 195, 212-213; Tekin (n 2) 161; Aydın (n 3) 41. Zira MTK m. 7/H’de Tahkim mahkemesine anlaşmanın geçerliliği ve hatta hakemlerin kendi yetkisi hakkında karar verme yetkisinin hakemlerde olduğunu belirtmiştir.

23 Nuray Ekşi, Hukuk Muhakemeleri Kanunu'nda Tahkim (2nd edn, Beta 2019), 28; Nomer (n 17) 585; Şanl, Esen and Ataman-Figanmeșe, (n 14) 693; Çelikel and Erdem (n 17) 790; Aydemir (n 3) 374; Özel (n 3$) 80$. 
Başka bir görüş ise, mahkemenin değerlendirmesini tahkim yargılamasının başlamış olup olmamasına göre derecelendirmiş, eğer tahkim yargılamasına başlanmışsa mahkemelerin derinlemesine bir inceleme yapmasının kompetenz-kompetenz prensibine ayrılık oluşturacağını, ancak henüz tahkim yargılamasına başlanmamış ise, mahkemenin, derinlemesine bir inceleme yapmasının yerinde olacağını ifade etmektedir ${ }^{24}$.

Doktrinde Erkan ise, tahkim anlaşmasının geçersizliği iddiası ile yokluğu iddiasının ayrı kavramlar olduğu kanaatindedir ${ }^{25}$. Erkan, devlet mahkemesinin, tahkim anlaşmasının yokluğu ya da varlığını tespit edebilecek bir yargılama yürütmesi gerektiğini, tahkim anlaşmasının geçersizliği konusunda ise prima facie bir inceleme gerçekleştirmesinin yeterli olacağını ifade etmektedir ${ }^{26}$. Hatta tahkim anlaşmasının geçersizliği konusundaki incelemenin hakem heyetince yapılması gerektiğini belirtmektedir ${ }^{27}$.

Türk hukukunda, bu konuda kabul görmüş bir uygulama mevcut değildir. Yargıtay bazı kararlarında kompetenz-kompetenz ilkesine vurgu yaparak mahkemenin prima facie bir inceleme yapmasi gerektiğine hükmetmiş ${ }^{28}$; bazı kararlarında ise, tahkim anlaşmasının geçerliliğinin mahkemece incelenmesi gerektiği yönünde karar vermiştir ${ }^{29}$.

Kanaatimizce, tahkim anlaşmasının devlet mahkemesi önünde derinlemesine bir incelemeye tabii tutulması, tahkim anlaşmasının devlet mahkemelerince denetlenmesi sonucunu doğuracaktır. Bu nedenle, devlet mahkemelerinin prima facie bir inceleme yapması daha yerindedir. Zira, taraflar, tahkim anlaşmasının geçersizliğini hakem mahkemesi önünde ileri sürebilecekleri gibi, iptal davası aşamasında ve tenfiz davası aşamasında da mahkeme önünde ileri sürebileceklerdir ${ }^{30}$. Başka bir

24 Akınc1, Milletlerarası Tahkim (n 3) 184-189; Yener Keskin (n 21) 245-248; Töre (n 8) 88-89. Kompetenz-Kompetenz (Yetki-Yetki) prensibinin olumlu ve olumsuz etkisi, İsviçre ve Fransız hukukunda uygulaması hakkında bkz. Özdemir Kocasakal (n 21) 526-527. Yetki-yetki prensibinin olumlu etkisi, hakem heyetinin kendi yetkisi hakkında öncelikli olarak kendisinin karar vermesidir. Olumsuz etkisi ise, mahkemelerin, bir tahkim anlaşmasının geçerliliği hakkında, o anlaşma ile kendisine yetki verilen hakem heyetinden önce karar verememesini ifade etmektedir. Fransız hukukunda, HMK m.1448 bu prensibin olumsuz etkisini kabul etmiş ve tahkim anlaşmasına konu uyuşmazlık, mahkemeye intikal ettirilirse, bir istisnai durum hariç, mahkemenin yetkisizlik kararı vereceği kabul edilmiştir. Bu istisnai durum, henüz uyuşmazlı̆ın hakem heyetine intikal ettirilmediği durumlara münhasırdır. Buna göre, henüz uyuşmazlık hakem heyetine intikal ettirilmemişse ve tahkim anlaşması açıkça geçersiz ve uygulanamaz ise mahkeme yetki konusunda karar verebilir. Yapılacak inceleme prima facia bir inceleme olup, inceleme sonucunda mahkeme geçerli bir tahkim anlaşmasının olduğu sonucuna varır ise, yetkisizlik kararı verir. Demek ki, dava, hakem heyetinde açılmışsa, sonra mahkemede açılmışsa, mahkeme, prima facia da olsa, hiçbir şekilde tahkim anlaşmasının geçerliliğini inceleyemez.

25 Erkan (n 22) 96.

26 Erkan (n 22) 96.

27 Erkan (n 22) 97. Karşı Yönde bkz Akınc1, Milletlerarası Tahkim (n 3) 183-189.

28 Yargitay 13 HD, 5227/1333, 06.02.2019: “...Bu kapsamda somut uyuşmazlık ele alındiğında, yukarıda tam haliyle aktarılan tahkim şartının, davacı bakımindan tesirsiz veya uygulanmasının imkansız olduğu sonucuna varılmakta olup, mahkemece, tahkime yönelik itirazın reddi ile işin esasının incelenmesi gerekirken, yazıl gerekçe ile davanın usulden reddine karar verilmiş olması bozmayı gerektirir." Yargitay 9 HD, 13952/27947, 24.09.2007; Yargitay 9 HD, 25759/109, 22.01.2007.

29 Yargıtay 15 HD, 3330/4607, 01.07.2014: "Dosyadaki yazılara, kararın dayandığı delillerle yasaya uygun gerektirici nedenlere ve özellikle sözleşmedeki tahkim şartının geçerli olup olmadığına karar verme yetkisinin görev ve yetkili hakem kuruluna ait olduğunun anlaşılmasına göre yerinde bulunmayan bütün temyiz itirazlarının reddiyle usul ve yasaya uygun olan hükmün ONANMASINA, ... oyçokluğuyla karar verildi." Yargitay 15 HD, 2145/4389, 27.06.2007.

Esen, 'kompetenz kompetenz' (n 21) 358-359. 
ifadeyle, itiraz aşamasında derinlemesine bir inceleme yapılmaması, yargılama açısından bir eksiklik doğurmayacaktır. Zira, tahkim anlaşmasının geçerlilik denetimi, yukarıda da bahsettiğimiz üzere, (1) kompetenz-kompetenz prensibi gereği, hakem mahkemesi nezdinde, (2) ardından hakemlerin tahkim anlaşmasının geçerli olduğuna karar verip, tahkim yargılamasına devam etmesi ihtimalinde; verilecek nihai kararın iptali davasında ve (3) nihayetinde, tanıma tenfiz ülkesinde açlacak tenfiz davasında devam edecektir. Bu durumda, henüz tahkim yargılamasına başlamadan, tahkim ilk itirazı aşamasında, tahkim anlaşmasının geçerliliğinin mahkemece derinlemesine denetlenmesi, tahkimin amacına uygun olmayıp, tahkimden beklenen faydaların elde edilmesine mâni olacak ve tahkim sürecine zarar verecek niteliktedir. Hele hele tahkim yargılaması başladıktan sonra, hakemlerin kompetenz-kompetenz yetkisine rağmen, mahkemece derinlemesine bir inceleme yapilması, tahkimin amacına aykırı olup, kanaatimizce, tahkim hukuku ile bağdaşmamaktadır.

Hakemlerin kendi yetkileri hakkında karar verip veremeyecekleri meselesi, tüm hukuk sistemlerinde uzun süre tartışılagelmiş bir meselesidir. 4686 sayılı MTK'dan evvel, 1086 sayılı Hukuk Usulü Muhakemeleri Kanunu (HUMK) ${ }^{31}$ yürürlükte iken, Türk hukukunda hakemlerin kendi yetkileri, başka bir ifadeyle, tahkim anlaşmasının geçerliliği hakkında karar verebilmeleri HUMK m. $519^{32}$ hükmü nedeniyle kabul edilmiyordu. Zira, HUMK 519 hükmünde, bir ihtilafın hakemler huzurunda halledilip halledilemeyeceği meselesine ancak, mahkemece karar verilebileceği belirtilmekteydi ${ }^{33}$. Uygulamada da tahkim prosedürünü uzatmak isteyen taraf, hemen her zaman, HUMK m. 519 uyarınca hakemlerin yetkisine mahkeme nezdinde itiraz etmekle ve bu konuya ilişkin karara karşı temyiz yoluna başvurmakla tahkim sürecini mahkemelerde cereyan eden dava sürecinden daha uzun hale getirebilmekteydi ${ }^{34}$. HUMK m.519 hükmünde yer alan, tahkim anlaşmasının geçersizliği dahil hakemlerin yetkisizliği hakkında mahkemeye başvurulması imkanının kaldırılma sebebi; tahkim anlaşmasının geçerliliğinin ve dolayısıyla hakemlerin ihtilafı çözmekte yetkili olup olmadıklarının, mahkemelerce değil, hakemlerce incelenmesinin, tahkimin amaç ve ruhuna, dolayısıyla, modern tahkim sistemlerinde kabul edilen kompetenz kompetenz prensibine uygun olmasıdır. MTK m. 7/H bendi ile, akabinde HMK m. 422 hükmünde, hakem veya hakem kurulunun, tahkim sözleşmesinin mevcut veya geçerli olup olmadığına ilişkin itirazlar da dâhil olmak üzere, kendi yetkisi hakkında

31 Hukuk Usulü Muhakemeleri Kanunu Kanun Numarası: 1086 Kabul Tarihi: 18/6/1927 RG 18.06.1927/622, 623, 624.

32 "Bir nizain hakemler vasatisiyle halledilip edilemeyeceği hususunda tevellüt eden ihtilaflar mahkemece seri usulü凹 muhakeme ile hallolunur."

33 Ebru Șensöz, Milletlerarası Tahkim Kanunu’nda Hakem Kararlarına Karşı Başvuru Yolları, Hakem Kararlarının İptali, (L.L.M. thesis Galatasaray Üniversitesi 2005) 96-97, 115. Buna karşın, doktrinde, Karayalçın, hakemlerin yetkisiz olduğuna ilişkin itirazda bulunan tarafa hakem/hakem kurulu tarafından mahkemede dava açmak için süre verildiği halde, davalı bu yolu tercih etmez ise, hakemlerin kendi yetkileri hakkında karar verebileceğini ifade etmekteydi. Yargıtay'in da uzun süreden beri, hakemlerin kendi yetkileri hakkında karar verebilmelerine cevaz verdiği de belirtilmekteydi. Doktrinde, çoğunluk görüşünden farklı olarak, Üstündağa göre, hakemlere kompetenz-kompetenz yetkisi tanınmakla tahkimin sürüncemede bırakılması ihtimali ortadan kaldırılmış olup, kompetenz-kompetenzin tanınması durumunda, gerek hakemlerin ihtilafı görmeye yetkili olmadığı veya tahkim anlaşmasının geçerli olmadığına dair itirazın, gerekse de hakemlerin yetkisini aştığına dair itirazın belli bir usul kesiti içinde ileri sürülmesine gerek bulunmamaktadır (Tartışmalar için bkz."Milletlerarası Tahkim Konusunda Yasal Bir Düzenleme Gerekir Mi? II. Tahkim Haftası, Sempozyum-Bildiriler-Tartışmalar, 11 Nisan 1997”, Ankara 1997, 259). 
karar verebileceği kabul edilerek, bu sakıncalı durum MTK’nın kabulü ile milletlerarası tahkimde 2001 yllında ve HMK’nın kabulü ile milli tahkimde 2012 yılında önlenmiştir.

Tahkiminamacına, ruhuna,özüneuygunyasaldüzenlemelerin yeraldığı, modern tahkim sistemlerindeki kompetenz-kompetenz prensibinin kabul edildiği Türk tahkim hukukunda, mahkemece, yapilacak tahkim ilk itirazında derinlemesine inceleme yapılarak karar verilmesi yönteminin benimsenmesi kanaatimizce uygun değildir. Ancak, uygulamada nadiren de olsa görüldüğü gibi, tahkim anlaşmasının salt varlığ 1 durumunda mahkemelerin prima facie bir inceleme dahi yapmadan davayı usulden reddi de yerinde olmayacaktır. Bu durumda da, baştan itibaren açık bir geçersizliği bulunan tahkim anlaşmasına dayanılarak yapılan tahkim yargılaması, zaman ve ekonomik kayba neden olacaktır ${ }^{35}$. Zira, kanaatimizce, Kanunda, "tahkim itirazının kabulü halinde" denilmekle, mahkemenin davaya bakmasını engelleyecek nitelikte "kabul edilebilir" 36 bir tahkim anlaşmasının bulunması aranmalıdır. Doktrinde Balkar Bozkurt tarafından da ifade edildiği gibi, mahkemenin tahkim itirazı üzerine yapacağı incelemede, "tahkim anlaşmasının hükümsüz, tesirsiz, uygulanması imkânsız" olup olmadığının tespit edilmesi gerektiğine ilişkin hükümlerin (NYS m.II/f.3 ve HMK m. 413), böyle bir hüküm içermeyen MTK m.5 hükmünün uygulanmasında da dikkate alınması gerekir. Ancak, doktrinde Erkan’ın da ifade ettiği üzere, bu yönde bir inceleme yaparken dahi, devlet mahkemesi, ilk aşamada mutlaka tahkim anlaşmasının yokluğu ya da varlığını tespit edebilecek bir yargılama yürütmelidir. Tahkim anlaşmasının esas kurucu unsuru, tahkim iradesinin varlığıdır. Eğer tarafların tahkim anlaşması kurmaya yönelik bir iradesi var ise, bu durumda tahkim anlaşmasının geçersizliği konusunda mahkemenin prima facie bir inceleme gerçekleştirmesi yeterli olacaktır.

Uygulamada, mahkeme nezdinde prima facie bir inceleme veya derinlemesine bir inceleme yapılarak karar verilse dahi, tahkim anlaşmasının geçersizliğine dair mahkemece verilen karar, kesin hüküm niteliğinde değildir ${ }^{37}$; bu karar bağlayıcı olmayacaktır ${ }^{38}$. Mahkemenin verdiği karar bağlayıcı olmadığından, tarafların aynı anda tahkim yoluna başvurması da mümkündür. Bu ihtimalde, tahkim yargılamasında hakem ya da hakem kurulu tahkim anlaşmasının geçerliliğine karar verdiği takdirde, paralel davalar ${ }^{39}$ gündeme gelecektir. Mahkeme ve tahkim arasında, aynı taraflar, aynı konu ve aynı sebebe dayanan derdestlik durumunu önleyecek bir milletlerarası derdestlik doktrini kabul edilmediğinden, bu iki dava aynı anda devam edecek ve ilk verilen nihai kararın hakem kararı olması durumunda, önce iptal davasında ve sonra tenfiz davasında; mahkeme kararı olması durumunda ise, önce kanun yollarına başvuru aşamasında, tahkim anlaşmasının geçerli olup olmadığı denetimi mahkemelerce yapilacaktır.

Yukarıda da ifade edildiği üzere, Türk hukukunda, MTK’nın uygulama alanına giren uyuşmazlıklarda; tahkim anlaşmasının geçerliliğine uygulanacak hukuk; MTK m. 4/f.3 “...Tahkim anlaşması, tarafların

35 Erkan (n 22) 96.

36 Şensöz (n 33) 97. Bu konuda bkz. I. C. Patolojik Tahkim Kavramı.

37 Erkan (n 22) 97.

38 Esen, 'kompetenz kompetenz' (n 21) 380.

39 Paralel davalar hakkında ayrıntılı bilgi için bkz. Nuray Ekşi, 'Milletlerarası Tahkimde Paralel Davalar (Parallel Litigation)' 20132 (2) UTTDER 15, 16 ff.; Gülüm Bayraktaroğlu Özçelik, Milletlerarası Usul Hukukunda Paralel Davalar, (1st edn, Yetkin 2016) $27 \mathrm{ff}$. 
tahkim anlaşmasina uygulanmak üzere seçtiği hukuka veya böyle bir hukuk seçimi yoksa Türk hukukuna uygun olduğu takdirde geçerlidir" hükmü uyarınca; taraflarca bir hukuk seçimi yapılmışsa bu hukuk, bir hukuk seçimi yoksa Türk hukukudur. MTK’nın uygulama alanına girmeyen uyuşmazlıklarda ise, bazı görüşler MTK m. 4 f.3’ün kıyasen uygulanması ve tahkim anlaşmasının geçerliliğine Türk Hukuku’nun uygulanması gerektiğini savunurken ${ }^{40}$, bazı görüşler ise yine farklı gerekçeler sunmakla birlikte, tahkim yeri hukukunun uygulanması gerektiğini ${ }^{41}$ savunmaktadır.

MÖHUK m.62/f.1 hükmü ile Türkiye’nin taraf olduğu sözleşmelerin içerdiği hükümler (NYS m.V/1/a ve Avrupa Cenevre Sözleşmesi m. 6/f.2) dikkate alındığında, Türk hukukunda, MTK’nın uygulama alanına girmeyen uyuşmazlıklarda, tahkim anlaşmasının geçerliliğine kanaatimizce de tahkim yeri hukuku uygulanmalıdır. Ancak tahkim yargılaması henüz başlamamış ve tahkim anlaşmasının geçersizliği itirazı devlet mahkemesinde tahkim itirazı üzerine inceleniyorsa ve tahkim anlaşmasında tahkim yeri belli değilse, bu durumda tahkim anlaşmasını geçerliliğine uygulanacak hukuk noktasında yine bir belirsizlik doğacaktır. Bu halde, Cenevre Konvansiyonu m. 6/f.2, yargılamayı yürüten mahkemenin kanunlar ihtilafı gereğince yetkili olan kanun hükümlerine göre değerlendirilme yapılması gerektiğini düzenlemektedir. Bu durumda kanaatimizce, MTK m. 5 hükmü çerçevesinde, Türk mahkemesinde tahkim itirazı yapıldığında, MTK m. 4/f.3, mevcut kanun boşluğu nedeniyle kıyasen uygulanarak, taraflarca tahkim anlaşmasının geçerliliğine uygulanacak hukuk seçimi yapılmamış ise, Türk hukukuna göre tahkim anlaşmasının geçerli olup olmadığı değerlendirilmelidir.

Görülüyor ki, tahkim anlaşmasının geçersizliğinin devlet mahkemesi önünde tahkim ilk itirazına karşı ileri sürmesi halinde de MTK’nın uygulama alanına giren hallerde, MTK m. 4/f.3 hükmüne göre, taraflarca tahkim anlaşmasının geçerliliğine uygulanacak hukuk seçimi yapılmış ise, seçilen hukuk; yapılmamış ise, Türk hukukuna göre tahkim anlaşmasının geçerli olup olmadığı değerlendirilmelidir.

\section{Tahkim Anlaşmasının Geçersizliğinin Mahkeme Önünde Iptal Davasında Illeri Sürülmesi}

Tahkim yargılaması sonunda verilen nihai karar, taraflardan birinin açtığ iptal davasında, tahkim anlaşmasının geçerliliği de dâhil olmak üzere (HMK m. 439 / (2) (a) ve MTK m.15 (A) (1) (a)), ilgili kanunda sayılı sinırlı iptal sebepleri bakımından incelemeye tabii tutulur ve iptal sebeplerinin varlı̆̆ 1

40 MTK m.4 f.3’ün herhangi bir kıstas belirlemeden Türk hukukunu işaret etmesi nedeniyle Türk hukukunun uygulanması gerektiği yönünde bkz Özel (n 3) 81. Kanun boşluğunun kıyasen MTK m.4/f.3 uygulanarak doldurulması ve Türk hukuku uygulanması gerektiği yönünde bkz Şanl, Esen and Ataman Figanmeşe, (n 14) 692-693 dn. 586; Esen, 'kompetenz kompetenz' (n 21) (ancak ifade etmek gerekir ki, Esen, ikili bir ayrım yapmakta ve, tahkim ilk itirazı olduğu hallarde kıyasen uygulama gerektiği görüşünü savunmaktadır. Aşağıda ayrıca ifade edileceği üzere, ikinci ihtimal olarak MTK’nın özel kanun, MÖHUK’un genel kanun olması nedeniyle, özel kanunda hüküm bulunmayan hallerde genel hükümlerinin uygulanması yoluyla çözülmesidir. Esen, 'Mevcut veya Belirli (14) 94-96.

41 MÖHUK hükümlerince En sıkı ilişkili hukuk olması nedeniyle tahkim yeri hukukunun uygulanması gerektiği yönünde bkz Esen,'Mevcut veya Belirli' (n 14) 96-97; New York Sözleşmesi kapsamında tahkim anlaşmasının geçerliliğine tahkim yeri hukukunun uygulanması gerektiği yönünde bkz Sarı̈̈z Büyükalp, (n 15) 2030; uyuşmazlı̆̆ın Cenevre Konvansiyonu kapsamına giren uyuşmazlıklar bakımından, Konvansiyon kapsamında taraflarca seçilen bir hukuk yoksa tahkim yeri hukukunun, eğer tahkim yeri hukuku da belirlenemiyorsa Türk hâkiminin kendi kanunlar ihtilafı kurallarının uygulanması gerektiği yönünde bkz Aydın (n 3) 47. 
halinde, karar iptal edilir. Tahkim anlaşmasının geçersizliği, hakem kararının iptali sebeplerinden biridir.

Tahkim anlaşmasının geçerliliğinin taraflarca bir hukuk seçilmişse seçilen hukuka göre, böyle bir hukuk seçimi yoksa, davanın açıldığı devlet mahkemesinin hukukuna göre değerlendirileceği genellikle kabul edilir ${ }^{42}$. Başka bir ifadeyle, Türk mahkemesinde iptal davası açıldığında taraflarca tahkim anlaşmasının geçerliliğine uygulanacak hukuk seçimi yapılmamışsa, bu tahkim anlaşmasının geçerliliği, Türk hukukuna göre değerlendirilmelidir. Türk hukukunda da, MTK m.4/f.3 hükmünde ${ }^{43}$, taraflara tahkim anlaşmasının geçerliliğine uygulanacak hukuku seçme imkânı tanınmış, böyle bir seçim olmaması durumunda ise, tahkim anlaşmasının geçerliliğinin Türk Hukuku’na göre değerlendirileceği hükme bağlanmıştır.

Doktrinde, tahkim anlaşmasının geçersizliğinin ilk kez iptal davası aşamasında ileri sürülmesinin, dürüstlük kuralına aykırılık oluşturacağı kabul edilmektedir ${ }^{44}$. Şöyle ki, tahkim yargılaması esnasında geçersizlik itirazında bulunmamasına karşın; hakem seçmiş, tahkim yargılamasına katılmış tarafın, iptal davası aşamasında tahkim anlaşmasının geçersizliğini ilk kez ileri sürmesi, iyi niyet kurallarına aykırıdır ${ }^{45}$.

Gerçekten de, 4721 sayılı Türk Medeni Kanunu ${ }^{46}$ m. 2 hükmü aynen, "Herkes, haklarını kullanırken ve borçların yerine getirirken dürüstlük kurallarına uymak zorundadır (f.1). Bir hakkın açıkça kötüye kullanılmasını hukuk düzeni korumaz (f.2)" şeklindedir. 6100 sayılı HMK m.29 hükmüne göre de, "Taraflar dürüstlük kuralına uygun davranmak zorundadırlar". HMK md. 29/1 ile TMK $\mathrm{m} .2$ hükmünde yer alan dürüstlük kuralı açıkça medeni usul hukukuna dâhil edilmiş ve tarafların usul hukuku çerçevesinde de dürüstlük kuralına uygun davranma zorunlulukları düzenlenmiştir ${ }^{47}$. Madde gerekçesinde, dürüstlük kuralına aykııı olması halinde işlemin hukuki sonuç doğurmasının mahkemece önleneceği ifade edilmiştir. İptal davasında, tahkim anlaşmasının geçersizliğinin ileri sürülmesi de bir "usuli itiraz", "usuli bir hakkın kullanılması"dır. O halde, dürüstlük kuralına aykırı olarak tahkim anlaşmasının geçersizliğine ilişkin usuli itirazın ilk kez iptal davasında ileri sürüldügünü tespit eden hâkimin, bu itirazı dikkate almama ve bu itiraza hukuki sonuç bağlamama imkânı vardır. Zira, bu durumda kanaatimizce de, tahkim yargılaması esnasında geçersizlik itirazında bulunmamasına karşın; hakem seçmiş, tahkim yargılamasına katılmış tarafın, iptal davası aşamasında tahkim anlaşmasının geçersizliğini ilk kez ileri sürmesi dürüstlük kuralının ihlali ve hakkın kötüye kullanılması olarak kabul edilmelidir. Tahkim anlaşmasının geçersizliğini ilk kez

42 Özel (n 3) 85; Fatih Işık, Milletlerarası Ticari Tahkimde Tahkim Anlaşması Yapma Yetkisi ve bu Yetkiye Uygulanacak Hukuk (1st edn, On İki Levha 2015) 122; Aydın (n 3) 55; Tekin (n 2) 166.

43 MTK m. 4 f.3 "Tahkim anlaşması, tarafların tahkim anlaşmasına uygulanmak üzere seçtiği hukuka veya böyle bir hukuk secimi yoksa Türk hukukuna uygun olduğu takdirde geçerlidir."

44 Şanlı (n 3) 427; Akıncı, Milletlerarası Tahkim (n 3) 402-403; Aydemir (n 3) 388; Aydın (n 3) 55; Tekin (n 2 ) 167.

45 Akıncı, Milletlerarası Tahkim (n 3) 402-403; Özel (n 3) 86; Tekin (n 2) 167-168.

46 Türk Medeni Kanunu, Kanun Numarası: 4721, Kabul Tarihi: 22/11/2001, RG 8.12.2001/24607.

476100 sayılı HMK öncesinde yürürlükte olan 1086 sayılı HUMK’nun uygulandığı dönemde de usuli hakların kötüye kullanılmasını yaptırıma bağlayan özel hükümler yer almakla birlikte, TMK m.2 hükmünde yer verilen dürüstlük kuralına benzer bir genel kural HUMK'da yer almamaktaydı bkz Emre Esen, 'Yabancı Mahkeme Lehine Yapılan Yetki Anlaşmasına Dayanan Yetki İtirazının Değerlendirilmesinde Dürüstlük Kuralının Etkisi ve Yargıtay 11. Hukuk Dairesinin 6.3.2009 tarihli İçtihadının Eleştirisi' (2011) 31 (1) MHB 191, 204. 
iptal davası aşamasında ileri süren tarafın iddiası, bu aşamada kabul edilirse, tahkim yargılaması tamamen boşa gidecektir.

\section{Tahkim Anlaşmasının Geçersizliğinin Kararın Tanınması ve Tenfizi Aşamasında Ileri Sürülmesi}

NYS m. V/1/a hükmü ${ }^{48}$, geçersiz bir tahkim anlaşması neticesinde verilen hakem kararının tenfiz edilemeyeceğini hükme bağlamıştır.

Tenfiz aşamasında geçerliliği incelenen tahkim anlaşması da, taraflarca bir hukuk seçilmişse bu hukuka göre değerlendirilir ${ }^{49}$. Böyle bir hukuk seçimi olmadığ 1 durumlarda ise, genellikle tahkim yeri mahkemesi hukukuna göre değerlendirme yapılacağı kabul edilir ${ }^{50}$. Aynı yönde 5718 sayılı Milletlerarası Özel Hukuk ve Usul Hukuku Hakkında Kanun m. 62/f. 1 hükmü, "Mahkeme ... (e) Tahkim sözleşmesi veya şartı taraflarca tâbi kılındığı kanuna, bu konuda bir anlaşma yoksa hakem hükmünün verildiği ülke hukukuna göre hükümsüz ise,... yabancı hakem kararının tenfizi istemini reddeder" hükmü ile, Türk hukuku açısından da, tahkim anlaşmasının geçerliliğinin, taraflarca seçilen hukuka, böyle bir hukuk seçimi yoksa, kararın verildiği yer hukukuna (tahkim yeri hukuku) göre geçerli olmaması halinde, tanınması veya tenfizinin mümkün olmayacağını düzenlemiştir.

NYS'de de "tahkim anlaşması taraflarca seçilen hukuka, böyle bir seçim yapılmamışsa tahkim yeri hukukuna göre esas bakımından geçerli olmalıdır" 51 şeklindeki m. V/1/a hükmü ile taraflarca bir hukuk seçimi yapılmamış olması durumunda tahkim anlaşmasının geçerliliğine uygulanacak hukuk tahkim yeri hukuku olarak belirlenmiştir.

Doktrinde, tenfiz davası aşamasında da, iptal davasında olduğu gibi, icraya ilişkin hareketlerde bulunmuş tarafın, tahkim anlaşmasını geçersizliğini ilk kez ileri sürmesinin, hakkın kötüye kullanılması olacağı ifade edilmektedir ${ }^{52}$. Yargıtay’n da tahkim anlaşmasının geçersizliğinin ilk kez tenfiz aşamasında ileri sürülmesinin dürüstlük kuralına aykırılık teşkil ettiğini ifade ettiği bir kararı mevcuttur ${ }^{53}$. Kanaatimizce, bu karar, tahkim anlaşmasının geçersizliğinin ilk kez iptal davası

48 New York Sözleşmesi m. V /1/a "Aleyhine hakem kararı dermeyan edilen tarafların talebi sekbetmez ve mumaileyh, kararın tanınması ve icrası istenen memleketin salahiyetli makamı huzurunda aşağıdaki hususları ispat etmez ise hakem kararının tanınması ve icrası talebi reddolunamaz; (a) II. maddede derpiş olunan anlaşmayı akdeden taraflar, haklarında tatbiki gereken kanuna göre ehliyetsiz olur yahut da mezkur anlaşma taraflarca tabi kılındiğı kanuna ve bapta sarahat mevcut değilse hakem kararının verildiği mahal kanununa göre hükümsüz bulunur ise; veya..."

49 Özel (n 3) 68; Ișık (n 42) 122; Tekin (n 2) 169.

50 Özel (n 3) 68; Ișık (n 42) 122; Tekin (n 2) 169.

51 "Recognition and enforcement of the award may be refused, at the request of the party against whom it is invoked, only if that party furnishes to the competent authority where the recognition and enforcement is sought, proof that: (a) The parties to the agreement referred to in article II were, under the law applicable to them, under some incapacity, or the said agreement is not valid under the law to which the parties have subjected it or, failing any indication thereon, under the law of the country where the award was made; or.."

52 Özel (n 3) 86; Aydemir (n 3) 394; Aydın (n 3) 59; Tekin (n 2) 169.

53 Yargıtay 11 HD, 6774/3751, 09.04.2004: “...ancak, her ne kadar davalı adına tahkim şartını da içeren sözleşmeyi imzalayan vekile verilen vekâletnamede tahkim şartı veya sözleşmesi imzalanma yetkisi mevcut değil ise de, davalı hakemde görülen davada kendisine defalarca yapılan tebligata rağmen tahkim şartının kendisi yönünden bu nedene dayalı olarak geçersiz olduğu yolunda bir itirazda bulunmamıştır. Şayet davalı hakem yargılaması sırasında böyle bir savunmada bulunsaydı 
aşamasında ileri sürüldüğü durumlarda da uygulanabilir bir karardır; bu kararda ifade edilen, “Tahkim şartını içeren sözleşme hükümlerinin yerine getirilmesinden sonra ve tahkim yargılaması sırasında böyle bir savunmada bulunmayan davalının hükmün kesinleşmesini müteakip tenfiz davası sırasında böyle bir savunmada bulunması M.K.nun 2.maddesinde yazılı iyiniyet kurallarına aykırıdır" görüşüne MK m.2 hükmü ve HMK m.29/1 hükmü çerçevesinde aynen katılmaktayız.

\section{B. PATOLOJIK TAHKIM KAVRAMI}

Yukarıda da belirttiğimiz üzere, doktrinde Eisemann bir tahkim anlaşmasında (i) taraflar açısından bağlayıcı sonuç doğurabilme, (ii) en azından hakemler tarafindan hüküm verilene kadar devlet mahkemesinin uyuşmazlığın çözümüne müdahalesini engelleme, (iii) uyuşmazlıkların çözümünde hakemlere taraflar aleyhine hüküm verme yetkisi tanıma, (iv) cebri icraya konu olabilecek bir hükmün verilmesine elverişli bir prosedürün uygulanması, temel işlevlerinin bulunması gerektiğini ifade etmektedir ${ }^{54}$.

"Patolojik tahkim" kavramı da, sayılan bu dört temel işlevden birinde veya birkaçında eksiklik bulunan tahkim anlaşmalarını ifade etmek için, ilk kez Eisemann tarafından kullanılmıștır ${ }^{55}$. Patolojik tahkim ile eş anlamlı olarak kullanılan "defective” Türkçe ifadeyle "kusurlu tahkim" kavramı ise ilk kez Schmitthoss tarafından kullanılmıştır ${ }^{56}$. Patolojik tahkimin genel kabul görmüş bir tanımı mevcut değildir. Basitçe; eksiklikler içeren bir tahkim anlaşması olarak ifade edilebilir ${ }^{57}$.

Doktrinde, Özdemir Kocasakal, patolojik tahkim anlaşmasını, "tahkim anlaşmasının zorunlu unsurlarının ${ }^{58}$ tutarlı bir şekilde ifade edilmediği veya bu unsurları muğlak veya çelişkili hale getiren

o takdirde davacıya bu savunmayı yerinde görerek uyuşmazlı̆̆ı mahkemede çözümlenmesi cihetine gidecek veya da tahkim şartının geçerli olduğu yolunda bir tesbit davası açarak gereksiz zaman ve masraf kaybını önlemiş olacaktı. Tahkim şartın içeren sözleșme hükümlerinin yerine getirilmesinden sonra ve tahkim yargılaması sırasında böyle bir savunmada bulunmayan davalının hükmün kesinleşmesini müteakip tenfiz davası sırasında böyle bir savunmada bulunması M.K.nun 2.maddesinde yazıl iyiniyet kurallarına aykırıdır. Bu itibarla mahkemece yabancı hakem kararını tenfizine karar verilmek gerekirken, anılan husus gözden kaçırılarak yazılı şekilde hüküm tesisi doğru olmamış, hükmün bu nedenle davacı yararına bozulması gerekmiştir".

54 Benjamin G Davis, 'Pathological Clauses: Frederic Eisemann's Still Vital Criteria' (1991) 7(4) Arbitration International 365-388, 365-366; Kasparas Tolkušinas, 'Defective Arbitration Clauses in International Commercial Contracts' (Mater Thesis, Mykolas Romeris University 2010)13; Harout J. Samra and Ramya Ramachanderan, 'A Cure for Every Ill? Remedies for "Pathological” Arbitration Clauses' (2020) 74(4) University of Miami Law Review 1110, 1111; Aydın (n 3) 30 naklen Eisemann (n 1) 130.

55 Davis (n 54) 365; Molfa (n 8) 162; Paul Comşa, 'At A Crossroads: The Case of "Pathological Arbitration Clauses" Which Determine A Jurisdictional Fight' (2018) 25(2) Lex ET Scientia International Journal 47, 48-49 Andrew Tweeddale and Keren Tweeddale, Arbitration of Commercial Disputes International and English Law and Practice (1st edn, Oxford University Press 2005) 117 dn. 95; Samra and Ramachanderan (n 54)1111; Jiangtao Qian and Liang Guo, 'The Validity and Remedy of the Pathological International Commercial Arbitration Agreement' (2019), 2(5) International Law School of Northwest University of Political Science and Law 109, 109; Alok Jain, 'Pathological Arbitration Clauses and Indian Courts' (2008) 25(4) Journal of International Arbitration 433, 433; Aydın (n 3) 30.

56 Tolkušinas (n 54) 3.

57 Tweeddale and Tweeddale (n 55) 117.

58 Tarafların karşılıklı ve birbirine uygun irade beyanları ile kurulan (TBK m.1) sözleşmenin kurulmuş sayılması için, tarafların sözleşmenin esaslı unsurları üzerinde anlaşmış olmalıdır (TBK m.2). Tarafların uyuşmazlığın çözümü 
ifadeler barındıran, bu nedenle, tahkim yargılamasının işlemesine engel olabilecek nitelikte bir tahkim anlaşması" olarak tanımlamaktadır ${ }^{59}$.

Tahkim anlaşması farklı sebeplerle patolojik hale gelebilir ${ }^{60}$. Tahkim anlaşmasının patolojik olarak nitelendirilmesinin başlıca sebepleri NYS m. II/f. $3^{61}$ ve UNCITRAL Model Kanun m. 8/f.1 ${ }^{62}$ de ifade edilen, tahkim anlaşmasının "hükümden düşmüş (inconsistency)", "tesirsiz (uncertainty)" ve "tatbiki imkânsız (inoperability)" olmasıdır ${ }^{63}$. Ancak belirtmek gerekir ki, eksiklik içeren her tahkim anlaşması hükümsüz ya da tatbiki imkânsız hale gelmez ${ }^{64}$.

O halde denilebilir ki; tahkim anlaşmasının patolojik veya başka bir ifadeyle kusurlu olmasının, tahkimin geçerliliğine etkisi; temel işlevlerini yerine getirip getirmediğine göre ya da NYS m. II f.3’te sayılan tahkime havale şartlarının gerçekleşmemiş olmasına göre her somut olayca ayrıca değerlendirilmelidir. Patolojik tahkim anlaşmaları bazı durumlarda geçersiz kabul edilse de, bazı durumlarda tarafların tahkim iradesini korumak için mahkemece yorumlanarak geçerli kabul edilebilir ${ }^{65}$.

Patolojik tahkim anlaşmalarının bir tanımı yapılması gerekirse; kanaatimizce patolojik ya da kusurlu tahkim anlaşmaları, tahkim iradesinde sakatliklar bulunan veya tahkim anlaşmasının icrasını olumsuz etkileyen eksiklikler ya da hatalar barındıran ve Eisemann tarafından ifade edildiği gibi, tahkim anlaşmasının "(i) taraflar açısından bağlayıcı sonuç doğurabilme, (ii) hakemler tarafindan hüküm verilene kadar devlet mahkemesinin uyuşmazlı̆̆ın çözümüne müdahalesini engelleme, (iii) uyuşmazlikların çözümünde hakemlere taraflar aleyhine hüküm verme yetkisi tanıma, (iv) cebri icraya konu olabilecek bir hükmün verilmesine elverişli bir prosedürün uygulanması" işlevlerinden birinde veya birkaçında eksiklik bulunan tahkim anlaşmalarıdır. Patolojik tahkim anlaşmasının tüm bu unsurlarını içine alan, daha öz bir tanım ise, doktrinde Özdemir Kocasakal tarafından yapılmıştır.

konusunda devlet yargısını bertaraf etmesi ve uyuşmazlığın bağlayıcı bir hakem kararı ile çözümünün kararlaştırılması ile hangi uyuşmazlığın tahkim yoluyla çözümleneceğinin belirlenmiş olması, tahkim anlaşmasının zorunlu iki unsurudur. Bkz. Özdemir Kocasakal (n 21) 515.

59 Özdemir Kocasakal (n 21) 513; Hatice Özdemir Kocasakal, 'Tahkim Şartı ile İlgili İptal Sebepleri” (2014) ICC Türkiye Yayını, XI. Milletlerarası Tahkim Semineri, 14 Nisan 2014, Ankara, 37, 62-63; Philippe Fouchard, Emmanuel Gaillard and Berthold Goldman, Traité de l'arbitrage commercial international (Litec 1996) 283; Gabrielle Kaufmann-Kohler and Antonio Rigozzi, Arbitrage international, Droit et pratique à la lumière de la LDIP (1st edn, Editions Weblaw 2006) 65; Şanl, Esen and Ataman-Figanmeşe, (n 14), 694-695

60 Tweeddale and Tweeddale (n 55) 117; Molfa (n 8) 163; Margaret L Moses, The Principles and Practice of International Commercial Arbitration (2nd edn, Cambridge 2012) 43; Jain (n 55) 434.

61 NYS m. II f. 3 "Bir Âkit Devlet mahkemesi, tarafların, işbu maddenin anladiğı manada anlaşma akdettikleri bir konu ile ilgili uyuşmazlıklarına el koyduğu takdirde, anlaşmanın hükümden düşmüş, tesirsiz veya tatbiki imkânsız bir halde olduğunu tespit etmedikçe, bunları, birinin talebi üzerine, hakemliğe sevkeder."

62 UNCITRAL Model Law on International Commercial Arbitration Article $8 / 1$ "(1) A court before which an action is brought in a matter which is the subject of an arbitration agreement shall, if a party so requests not later than when submitting his first statement on the substance of the dispute, refer the parties to arbitration unless it finds that the agreement is null and void, inoperative or incapable of being performed." <https://uncitral.un.org/sites/uncitral.un.org/files/mediadocuments/uncitral/en/19-09955_e_ebook.pdf> Erişim Tarihi: 07.08.2020.

63 Blackaby, Partasides, Redfern and Hunter (n 8) 135 dn. 305; Molfa (n 8) 163 dn. 5.

64 Tweeddale and Tweeddale (n 55) 117.

65 Moses (n 60) 33. 
Çalışmamızınkonusuolanhibrittahkimanlaşmalarıdauygulamadabazısorunlardoğurmasınedeniyle, patolojik olarak nitelendirilen tahkim anlaşmalarındandır. Hibrit tahkim anlaşmalarını incelemeden önce hibrit kelimesinin kökünü inceleyecek olursak; hibrit Eski Yunancada hýbris vißpıৎ yani "ölçüyü aşma" anlamında Latince hybrida yani "melez" ve Fransizca hybride veya İngilizce hybrid olarak aynı anlamda kullanılmaktadır ${ }^{66}$. Türkçe'de ise hibrit kelimesi "İki tür arasında yapılan birleştirmeler sonucu elde edilen yavru, iki farklı güç kaynağının bir arada bulunması ${ }^{67}$ "anlamında kullanılmaktadır. Çalışmamızın ana konusunu oluşturan hibrit tahkim anlaşmaları da, kelime kökeninde olduğu gibi birden fazla bileşen sentezlenerek oluşturulan tahkim anlaşmalarını ifade eder.

Hibrit tahkim anlaşmalarının evrensel kabul görmüş bir biçimi ve tanımı mevcut değildir ${ }^{68}$. Aşağıda inceleyeceğimiz üzere, iki farklı hibrit tahkim anlaşması bulunmaktadır; (1) iki farklı uyuşmazlık çözüm yoluna atıf yapılmak suretiyle kurulan hibrit tahkim anlaşmaları ve (2) bir tahkim merkezinin farklı bir tahkim merkezi kurallarına atıf yapılmak suretiyle yetkilendirilmesi şeklinde kurulan hibrit tahkim anlaşmaları.

\section{TAHKIM ILE BIRLIKTE BAŞKACA ALTERNATIF UYUŞMAZLIK ÇÖZÜM YÖNTEMLERINE ATIF YAPILAN HIBRIT TAHKIM ANLAŞMALARI}

Bir tahkim anlaşmasının temel kurucu unsuru olan tahkim iradesi, açık ve kesin olmalıdır ${ }^{69}$. Ancak uygulamada, tarafların, tahkim anlaşmasında, tahkim ile birlikte başka alternatif uyuşmazlık çözüm yollarına da atıf yaptığ ${ }^{70}$ ya da devlet mahkemelerini de yetkilendirdiği görülmektedir ${ }^{71}$.

Tarafların tahkim yargılaması ile birlikte başka alternatif uyuşmazlık çözüm yollarına başvuruyu öngördügü tahkim anlaşmaları, kombine "combined processes" ya da karma tahkim anlaşmaları "hybrid prosses" olarak adlandırılmaktadır 72 . Benzer ifade ile, tarafların tahkim yargılaması ile birlikte

$66<$ https://www.nisanyansozluk.com > Erişim tarihi: 03 February 2020

67 Türk Dil Kurumu (TDK) Sözlüğü <https://sozluk.gov.tr $>$ Erişim tarihi: 03 February 2020.

68 Yasunobu Sato, 'Hybrid Dispute Processing in Japan: Linking Arbitration with Conciliation' Vijay K. Bhatia, Christopher N. Candlin, Jan Engberg and Jane Lung (eds), Legal Discourse across Cultures and Systems (Kluwer Academic 2008) 56.

69 Ertekin and Karataş (n 8) 65-66; Akıncı, Milletlerarası Tahkim (n 3) 133,134-148; Töre (n 8) 8; Ekşi, HMK (n 23) 7374; Gedik (n 8) 92. Yargıtay 15 HD 1438/2153, 13.04.2009: "Kişiler arasında çıkan ihtilafların kural olarak mahkemeler eliyle çözülmesi gerekir ise de, taraflar imzaladikları sözleşmede ihtilafin hakemler eliyle çözümlenmesini (tahkim şartı) kararlaştırabilecekleri gibi, asıl sözleşmeden müstakil olarak hakem sözleşmesi de imzalayabilirler. HUMK'nin 518. Maddesi uyarınca, iki tarafın arzularına tabi olmayan mesailde tahkim cereyan etmeyeceğinden, bunun dışında kalan ihtilaflar için davanın hakemde görülmesi kararlaştırılabilir. Ancak, tahkim iradesi hiçbir tereddüde yer vermeyecek şekilde açık ve kesin olmal, tarafların ihtilafin hakemde görülmesi iradesi kararl bulunmalıdır. Her ne kadar davaya esas sözleşmenin 15. Maddesinde, uyuşmazlik halinde ihtilafin hakem kurulunda çözümlenmesi öngörülmüssse de, aynı maddenin sonunda, ihtilaflar halinde İstanbul Mahkemelerinin yetkili bulunduğu kabul edilmiştir. Bu durumda kesin bir tahkim iradesinden söz edilemeyeceğinden ve kural olarak mahkemelerin ihtilafı çözmesi gerektiğinden, mahkemece tahkim itirazının reddi ile işin esasının incelenip davanın sonuçlandırılması yerine, dava dilekçesinin görev yönünden reddi doğru olmamış, kararın bozulması uygun bulunmuştur."

70 Moses (n 60) 14; Didem Kayal,, 'Enforceability of Multi-Tired Dispute Resolution Dispute Clauses' (2010) 27(6) Journal of International Arbitration 551, 552.

71 Bilgehan Yeşilova, Milletlerarası Ticari Tahkimde Nihai Karardan Önce Mahkemelerin Yardımı ve Denetimi (1st edn, Güncel 2008) 523.

72 Nuray Ekşi, Tahkim Öncesi Uyuşmazlık Çözüm Usulleri ve Bu Usuller Tüketilmeden Tahkime Başvurulmasının Sonuçları 
kademeli olarak devlet mahkemelerini de yetkili kıldıkları durumlarda da hibrit tahkim anlaşması düzenlemiş olacaklardır ${ }^{73}$.

\section{A. TAHKIM ÖNCESI AŞAMALAR}

Taraflar, uyuşmazlıklarının, tahkime gitmeden önce, müzakere veya arabuluculuk gibi uyuşmazlık çözüm yollarıyla, sonuç elde edilememesi halinde tahkim yoluyla kademeli olarak çözülmesini öngörebilir ${ }^{74}$. Tarafların en az iki farklı uyuşmazlık çözüm yolu öngördüğü tahkim anlaşmaları "çok katmanlı - çok aşamalı ${ }^{75}$ " tahkim anlaşmaları olarak adlandırılmaktadır ${ }^{76}$.

Tarafların birden fazla uyuşmazlık çözüm yolunu öngördüğü tahkim anlaşmaları, klasik bir tahkim anlaşmasından farklı olarak, tarafların spesifik ihtiyaçlarına göre düzenlenir ${ }^{77}$. Bu tür anlaşmalarda taraflar, bir önceki adımda sonuca ulaşamamaları durumunda, uyuşmazlıklarını bir sonraki adımdaki çözüm yolu önüne getirirler ${ }^{78}$. Kademeli tahkim anlaşmalarında genellikle tahkim son basamak olarak belirlenir ${ }^{79}$. Çoğunlukla, kademeler ilerledikçe, tarafların çözüm üzerindeki iradesi azalacak şeklide bir düzenleme gerçekleştirilir ${ }^{80}$.

Hibrit tahkim ile ifade edilmek istenen; tahkim ve başkaca çözüm yollarının birlikte sentezlenerek kullanılmasıdır ${ }^{81}$. O halde, benzer şekilde, tahkim yargılamasından sonra, son kademe olarak devlet yargısı öngörüldüğü hallerde de hibrit bir tahkim anlaşması akdedilmiş olur $^{82}$.

Bu tür "kademeli" tahkim anlaşmalarının, taraflara (1) uzun süreli ticari ilişkilerde aralarındaki sözleşmenin uygulanmaya devam etmesinin sağlaması ${ }^{83}$, (2) ilerideki iş ilişkilerinin olumsuz etkilenmemesi ${ }^{84}$, (3) tahkime gidecek kadar büyük bir uyuşmazlık olmaması durumunda

(1st edn, Beta 2015) 4.

73 Deyan Draguiev, 'Unilateral Jurisdiction Clauses: The Case for Invalidity, Severability or Enforceability' (2014) 31(1) Journal of International Arbitration 19, 20.

74 Blackaby, Partasides, Redfern and Hunter (n 8) 100; Ekşi, Tahkim Öncesi (n 72) 15, 18; Kayalı (n 70) 551; Moses (n 60) 14; Yeșilova, Mahkemelerin Yardımı (n 71) 523; Mine Tan Dehmen M, Tahkim Öncesi Müzakere Ya Da Uzlaștırma Yollarının Tüketilmiş Olmasının Tahkim Yargılamasına Etkisi (2011) 25(1-2) PPIL 451, 457; Demirkol (n 17) 328; Aydın (n 3) 104.

75 "multi-tier arbitration clauses".

76 Blackaby, Partasides, Redfern and Hunter (n 8) 100; Ekşi, Tahkim Öncesi (n 72 ) 17.

77 Kayalı (n 70) 551.

78 Kayalı (n 70) 552.

79 Kayalı (n 70) 552.

80 Ekși, Tahkim Öncesi (n 72) 18; Wian Erlank W, Enforcement of Multi-Tiered Dispute Resolution Clauses (SSRN, 9 September 2002) <https://papers.ssrn.com/sol3/papers.cfm?abstract_id=1491027> Erişim tarihi 5 June 2020, 8-9.

81 H William Ross and Donald E Conlon , 'Hybrid of Third-Party Dispute Resolution: Theoretical Implications of Combining Mediation and Arbitration' (2000), 25(2) The Academy of Management Review 416, 416.

82 Ekşi, Tahkim Öncesi (n 72) 19.

83 Ekşi, Tahkim Öncesi (n 72) 19.

84 Kayalı (n 70) 552-553. 
zaman ve maliyet kaybının önüne geçilmesi ${ }^{85}$ ve (4) tahkim öncesi aşamanın bir soğuma süresi sağlaması ${ }^{86}$ gibi nedenlerle avantaj sağladığı belirtilmektedir. Kademeli tahkim anlaşmalarının dezavantajlarının ise, (1) uyuşmazlık çözüm yolunun sonuca ulaşamaması durumunda tahkim yargılamasının gecikecek hatta engellenecek olmasi ${ }^{87},(2)$ taraflara bir sonraki kademede verilecek karar konusunda bir fikir oluşturması ${ }^{88}$ ve (3) tahkim anlaşmasının düzenlenmesinde dikkat edilmemesi durumunda tahkim anlaşmasını icra edilemez hale getirebilmesi ${ }^{89}$ olduğu ifade edilmektedir.

\section{Med-Arb}

En bilinen kademeli hibrit tahkim prosedürü, med-arb başka bir ifadeyle arabuluculuk - tahkimdir ${ }^{90}$. Kademeli hibrit tahkim anlaşmalarından med-arb da arabuluculuğun dostane niteliği ve tahkimin bağlayıcılık niteliği birleştirilir91.

Med-Arb prosedüründe, öncelikli olarak arabuluculuk çözüm yolu tüketilir, bu yol ile çözüme ulaşılamaması halinde, tahkim yoluna gidilir ${ }^{92}$. Hakem olarak seçilen kişi, öncelikle arabuluculuk yapar, arabuluculuğun başarısız olması durumunda ise tahkim aşamasına geçilir ${ }^{93}$. Hakem ve arabulucuların aynı kişi olması tartışmalı bir konu olmasına karşın, hakem ve arabulucunun aynı kişi olması önünde engel yoktur ${ }^{94}$. Bu doğrultuda arabulucunun otomatik olarak hakem olmasının, hızlı bir çözüm sunduğunu ancak yine de arabuluculuk aşamasında hakemlerin önyargısı olacağını ifade eden bir görüş olmakla birlikte ${ }^{95}$, diğer bir görüş ise, aksi kararlaştırılmadıkça, arabulucunun hakem olmayacağını savunmaktadır ${ }^{96}$. Gerçekten de bir önceki basamakta arabuluculuk yapan

85 Erlank (n 80) 9.

86 William W Park, 'Arbitration of International Contract Disputes' (1984) 39(4) The Business Lawyer 1783, 1788.

87 Blackaby, Partasides, Redfern and Hunter (n 8) 101; Ekşi, Tahkim Öncesi (n 72) 19.

88 Ekși, Tahkim Öncesi (n 72) 19.

89 Kayalı (n 70) 552.

90 Ross and Conlon (n 81) 417.

91 Cemile Demir Gökyayla, 'Arabuluculuk ve Tahkimi Bir Arada İçeren Uyuşmazlık Çözüm Yolu’ (2019) 77 (2) İstanbul Hukuk Mecmuası 575, 580-581; Berk Demirkol and Ural Aküzüm, Türkiye'de Med-Arb (Arabuluculuk-Tahkim) Yapisl, Mevzuatı \& Uygulamast (1st edn, On İki Levha 2020) 4.

92 Mauro Rubino Sammartano, International Arbitration Law and Practice (2nd edn, Kluwer Law International 2001)19; Ross and Conlon (n 81) 417; Sato (n 68) 61; Ekşi, Tahkim Öncesi (n 72) 4-5; Akınc1, Milletlerarası Tahkim (n 3)19; Demir Gökyayla (n 91) 579; Demirkol and Aküzüm (n 91) 57.

93 Rubino Sammartano (n 92) 19; Ross and Conlon (n 81) 417; Sato (n 68) 61; Ekşi, Tahkim Öncesi (n 72) 4-5; Akınc1, Milletlerarası Tahkim (n 3)19; Demir Gökyayla (n 91) 579; Demirkol and Aküzüm (n 91) 57.

94 Ross and Conlon (n 81) 417; Ekşi, Tahkim Öncesi (n 72) 5; Akıncı, Milletlerarası Tahkim (n 3) 22; Ildır (n 8) 100; Demirkol and Aküzüm (n 91) 67; Haig Oghigian, 'The Mediation/Arbitration Hybrid' (2003), 20(1) Journal of International Arbitration 75, 76. Türk hukuku açısından MTK, HMK ve Hukuk Uyuşmazlıklarında Arabuluculuk Kanunu (HUAK)'da arabulucuların hakem olmasını yasaklar hükümler bulunmamaktadır. Bkz Akıncı, Milletlerarası Tahkim (n 3) s.22; Demir Gökyayla (n 91) 592-593.

95 Sato (n 68) 61; Ildır (n 8) 102; Demirkol and Aküzüm (n 91) 68. Bu eleştirileri ortadan kaldırmak için (Arb-Med-OptOut) Med-Arb devre dışı bırakma sistemi önerilmektedir. Arb-Med-Opt-Out sistemi, arabulucunun yargılamayı tahkime çevirmesi üzerine, taraflara veto yetkisi vermektedir. Bkz Sato (n 68) 61. 
kişinin aynı uyuşmazlık için hakem olması, hakemlerin arabuluculuk sırasında öğrendiklerinin etkisinde karar vermesi ihtimali ortaya çıkacak, hakemlerin tarafsız kalarak karar veremeyeceği endişesi ve arabulucuların hakem olma gücüne sahip olması nedeniyle tarafları sulh olmaya zorlaması gibi sakıncalar meydana gelebilecektir ${ }^{97} .2018$ tarihli UNCITRAL Uluslararası Ticari Arabuluculuk ve Arabuluculuk Sonucu Elde Edilen Uluslararası Sulh Anlaşmaları Hakkında Model Kanun ${ }^{98}$ ve 2019 yllında İstanbul Tahkim Merkezi (ISTAC) bünyesinde yayınlanan MedArb kurallar. ${ }^{99}$ da bu görüş çerçevesinde taraflar aksini kararlaştırmadıkça, arabulucunun hakem olarak görev yapamayacağını kabul etmiştir ${ }^{100}$. Taraflar ve arabulucular için bağlayıcı nitelikte olan Türkiye Arabulucular Etik Kuralları ${ }^{101}$ nın "Menfaat İlişkisi ve Çatışması" başlıklı 4 (6) maddesi uyarınca da arabulucu, ancak taraflar açık ve yazılı onayları ile birlikte talep ederlerse, açılan tahkim yargılamasında hakemlik yapabilir.

\section{Arb-Med-Arb}

Arb-Med-Arb prosedürü ise, Med-Arb’n başka bir varyasyonu olarak karşımıza çıkmaktadır. Tarafların aralarında, yalnızca tahkim anlaşması bulunduğu durumlarda, tarafların uyuşmazlıklarını arabuluculuğa götürme noktasında anlaşmaları ile Arb-Med-Arb prosedürü oluşur ${ }^{102}$. Taraflar, tahkim yargılaması başlamadan önce, arabulucuya gitme noktasında anlaşabilecekleri gibi; yargılama başladıktan sonra, yargılamaya devam edilirken de arabulucuya gitmeyi kararlaştırabilirler ${ }^{103}$. Doktrinde, bu durumda, fiili olarak kurulan bir Arb-Med-Arb anlaşması oluştuğu ifade edilmektedir ${ }^{104}$.

97 Akınc1, Milletlerarası Tahkim (n 3) 21-25; Demir Gökyayla (n 91) 595-599; Oghigian (n 94) 77.

98 https://uncitral.un.org/sites/uncitral.un.org/files/media-documents/uncitral/en/annex_ii.pdf (Erişim Tarihi: 03.08.2020).

99 https://istac.org.tr/wp-content/uploads/2019/11/ISTAC-Arabuluculuk-Tahkim-Kuralları-Med-Arb.pdf (Erişim Tarihi: 03.08.2020).

100 UNCITRAL Model Law on International Commercial Mediation and International Settlement Agreements Resulting from Mediation Article 13, "Unless otherwise agreed by the parties, the mediator shall not act as an arbitrator in respect of a dispute that was or is the subject of the mediation proceedings or in respect of another dispute that has arisen from the same contract or legal relationship or any related contract or legal relationship." ISTAC MedArb Kuralları m. 5 f. 1, "Arabuluculuk-tahkim veya arabuluculuk süreçlerinde arabulucu olarak görev yapan kişi, tarafların açık ve yazılı onayı olmaksızın, aynı uyuşmazlık hakkındaki tahkim yargılamasında hakem olarak görev yapamaz.".

101 https://adb.adalet.gov.tr/Sayfalar/Teskilat/mevzuat/etik_kurallar.html. Madde 4 (6) "Arabulucu, bu sıfatla görev yaptı̆̆ uyuşmazlik ile ilgili olarak açılan davada, daha sonra, avukat olarak görev üstlenemez. Ancak, taraflar açık ve yazılı onaylart ile birlikte talep ederlerse, açılan tahkim yargılamasında hakemlik yapabilir".

102 Rubino Sammartano (n 92)19; Demir Gökyayla (n 91) 591; Demirkol and Aküzüm (n 91) 58-59.

103 Rubino Sammartano (n 92)19; Demir Gökyayla (n 91) 591; Demirkol and Aküzüm (n 91) 58-59.

104 Demirkol and Aküzüm (n 91) 58-59 


\section{MEDOLA}

Med-arb’’n görünüş şekillerinden biri de $M E D O L A{ }^{\prime} \mathrm{d}_{1}{ }^{105}$. MEDOLA, arabuluculuk ile lastoffer arbitration ${ }^{106}$ sistemlerinin hibrit olarak sentezlenmesi şeklinde karşımıza çıar ${ }^{107 .}$ Arabuluculuk ve "last-offer arbitration" sistemlerinin birleşiminden oluşan medola sisteminde, taraflar arabuluculuğun başarısız olması halinde, tahkim yargılamasında hakeme son tekliflerini sunarlar ve hakem, bu teklifler arasında bir seçim yaparak çözüme ulaşılır ${ }^{108}$. Kavramı ortaya atan Coulson, Medola sisteminde, tahkim yargılaması aşamasında hakemlerin tarafların teklifleri ile bağlı olması nedeniyle, arabuluculuk aşamasında tarafların aralarında özgürce müzakere gerçekleştirebilmelerinin mümkün kılındığını ifade etmektedir ${ }^{109}$. Başka bir ifade ile, Medola sistemi, tarafların, tahkimden önce gerçekleştirdikleri müzakerelerinin, ileride aralarında başlayacak tahkim yargılamasını etkilemeyecek şekilde gerçekleştirebilmeleri bakımından MedArb sisteminden ayrilmaktadır ${ }^{110}$.

\section{Arb-Med}

Arb-Med (arbitration-mediation) tahkim-arabuluculuk ise, kademeli hibrit tahkim anlaşmalarının diğer bir görünüş biçimi olarak karşımıza çıkmaktadır. Arb-Med usulünde, tahkim yargılamasında hakem karar verdikten sonra ancak kararını henüz açılamadan önce, taraflar son bir şans olarak arabuluculuğa başvururlar ${ }^{111}$. Arabuluculuk faaliyetinden sonuç alınamaması üzerine, hakem, önceden varmış olduğu kararı taraflara açıklar ${ }^{112}$. Arb-Med usulünün, hakemin kararının arabuluculuk aşamasından önce vermiş olması yönüyle, Med-Arb usulünden ayrıldığı ifade edilmektedir ${ }^{113}$. Ancak bu sistem, tahkim yargılamasında bir karar verildikten sonra arabuluculuğa gidilmesi nedeniyle, tahkimin hızlı ve masrafsız bir çözüm sunması beklentisini ortadan kaldıracağı eleştirisine maruz kalmaktadır ${ }^{114}$.

105 Rubino Sammartano (n 92) 20.

106 "last-offer arbitration"da; taraflar, son tekliflerini sunarak, arasında seçim yaparak karara varması için bir kişi yetkilendirirler. Bkz Robert Coulson, 'MEDALOA: A Practical Technique for Resolving International Business Disputes' (1994) 11(2) Journal of International Arbitration, 111, 111.

107 Coulson (n 106) 111.

108 Coulson (n 106)111; Rubino Sammartano (n 92) 20; Sato (n 68) 61.

109 Coulson (n 106) 112.

110 Coulson (n 106) 112.

111 Ross and Conlon (n 81) 418; Ekşi, Tahkim Öncesi (n 72) 5; Akıncı, Milletlerarası Tahkim (n 3) 27-28; Demir Gökyayla (n 91) 601.

112 Ross and Conlon (n 81) 418; Ekşi, Tahkim Öncesi (n 72) 5; Akıncı, Milletlerarası Tahkim (n 3) 27-28; Demir Gökyayla (n 91) 601.

113 Demir Gökyayla (n 91) 602.

114 Akıncı, Milletlerarası Tahkim (n 3) 28. 


\section{Tahkim Öncesi Kademeli Tahkim Anlaşmalarının Geçerliliği}

Doktrinde, kademeli hibrit tahkim anlaşmalarında tarafların tahkim iradesi konusunda bir tartışma bulunmamakta ve kademeli hibrit tahkim anlaşmaları geçerli kabul edilmektedir ${ }^{115}$. Buna karşın, kademeli tahkim anlaşmalarında, uyuşmazlık çözüm yöntemleri için bir süre şartı belirlenmesi, tahkim öncesi aşamaların zorunlu olup olmadığı, tahkim öncesi aşamanın tüketilmediği durumlarda tahkime başvuru engelinin bulunup bulunmadığı gibi konuların ayrıntılı şekilde düzenlenmesinin oldukça önemli olduğu ifade edilmektedir. Zira, çelişki veya anlam karmaşası oluşması durumunda, kademeli tahkim anlaşmaları patolojik hale gelebilecektir ${ }^{116}$. Türk hukukunda da, Yargıtay’ın, bu tip kademeli tahkim anlaşmalarını geçerli kabul ettiği kararları mevcuttur ${ }^{117}$.

Kademeli tahkim anlaşmaları konusunda incelenmesi gereken bir başka husus ise, anlaşmada belirlenen diğer alternatif çözüm yollarına başvurmadan, doğrudan tahkim yargılamasına gidilip gidilemeyeceği, başka bir ifadeyle tahkim öncesi belirlenen alternatif uyuşmazlık çözüm yollarının tüketilmesi gerekip gerekmediğidir ${ }^{118}$. Bu noktada doktrinde, tahkim anlaşması öncesi öngörülen aşamaların zorunlu ya da ihtiyari olmasına göre bir ayrım yapılmaktadır ${ }^{119}$.

Doktrinde Akıncı, tahkim öncesi aşamanın zorunlu ya da ihtiyari olmasına bakılmaksızın, tüketilmemesinin tek istisnasını taraflardan birinin çaba sarf etmesine karşın, diğer tarafın katılım sağlamaması olarak ifade etmektedir ${ }^{120}$. Bu istisna hariç, taraflarca tahkim öncesi aşamanın zorunlu ya da ihtiyari olarak kararlaştırılmış olmasına bakılmaksızın tüketilmesi gerekmektedir.

115 Ekşi, Tahkim Öncesi (n 72) 47; Akıncı, Milletlerarası Tahkim (n 3)146-147; Demirkol (n 17) 329; Park (n 86) 1788; Tan Dehmen (n 74) 458.

116 Blackaby, Partasides, Redfern and Hunter (n 8) 101-102; Febie Yudistiana, 'The Extent To Which Hybrid Arbitration Clauses Apply To Advance Investor-State Arbitration In The International Centre For Settlement Of Investment Disputes (ICSID)' (LLM thesis, Kingston University London, 2015) 55; Ekşi, Tahkim Öncesi (n 72) 23; Aydın (n 3) 116. İngiliz Mahkemeleri tahkimden önce arabuluculuk öngörülmüş olan Sulamerica davası (Sulamerica CIA Nacional De Seguros SA \& Ors v Enesa Engenharia SA \& Ors [2012] EWHC 42 (Comm) <http://www.bailii.org/cgi-bin/format.cgi?doc=/ ew/cases/EWHC/Comm/2012/42.html\&query=(Sulamerica)> Erişim Tarihi: 31.07.2020 ve tahkimden önce iki aşamalı öngörülmüş olan Wah (Aka Alan Tang) \& Anor v Grant Thornton International Ltd davasında (Wah (Aka Alan Tang) \& Anor v Grant Thornton International Ltd \& Ors [2012] EWHC 3198 (Ch) <http://www.bailii.org/cgi-bin/format. cgi?doc=/ew/cases/EWHC/Ch/2012/3198.html\&query=(Wah)+AND+((aka)+AND+(Tang)> Erişim Tarihi: 31.07 .2020 tahkim anlaşmasının geçersiz olduğuna hükmetmiştir.

117 Yargitay 15 HD, 1854/4946, 15.09.1994: “Taraflar arasındaki sözleşmenin 67. Maddesinde açıkça bu sözleşmeden uygulanmasından doğacak her türlü uyuşmazlıkların hakemde çözüleceği kararlaştırılmıştır. Hakeme başvurmadan önce taraflardan birisinin sözleşmenin icrasından doğacak anlaşmazlıklar için önce mühendise başvurulacă̆ına dair hüküm hakem şartını geçersiz kılmaz. Çünkü öncelikle taraflar veya bunlardan birisi mühendise başvursun veya vurmasın sonuçta uyuşmazlığın hakemde çözülmesi gerekir. Hakemden önce mühendise başvurulması prosedürü ve mühendisin vereceğ karar tarafları bağlayıcı değildir. Bu nedenle sözleşmedeki bu hüküm hakem şartını geçersiz kılmayacağından ve dairemizin emsal kararları da bu yönde olduğundan mahkemenin hakem şartının geçersiz olduğuna ilişkin kararının bozulması gerekmiştir.” Bkz. Ertekin and Karataş (n 8) 55-56, 72.

118 Demirkol (n 17) 329 dn 12.

119 Tan Dehmen (n 74) 459; Aydın (n 3) 110. Taraflar tahkim öncesi aşamayı ihtiyari olarak öngörebilecekleri gibi, zorunlu bir aşama olarak da anlaşmalarına ekleyebilirler. Bkz. Tan Dehmen (n 74) 459; Ekşi, Tahkim Öncesi (n 72) 28; Demir Gökyayla (n 91) 586; Demirkol and Aküzüm (n 91) 63.

120 Ziya Akıncı, Milletlerarası Özel Hukukta İnşaat Sözleşmeleri (1st edn, Dokuz Eylül Üniversitesi, 1996$) 138$. 
Doktrinde Özbek de aynı yönde, tahkim öncesi aşamaların zorunlu olması ya da olmaması ayrımı yapmadan tüketilmesi gerektiği görüşündedir ${ }^{121}$. Bu nedenle, tarafların aralarında yapacakları tahkim anlaşmasında, tahkim öncesi aşama tüketilmeden davaya geçilemeyeceği konusunda açı hüküm getirmesinin yerinde olacağını ifade etmektedir ${ }^{122}$.

Aksi yönde bir görüş ise, tahkim öncesi aşamanın zorunlu ya da ihtiyari olmasına bakılmaksızın, tüketilmemesinin, tahkim yargılamasını etkilemeyeceğini savunmaktadır ${ }^{123}$. Doktrinde Yeşilırmak, arabuluculuk ve müzakerenin Türk hukukunda "taraf iradesine bağl dostane uyuşmazlık çözüm yolları" olduğunu ve Türk hukuku açısından, tarafların bu usullere başvurmaya zorlanamayacakları görüşündedir ${ }^{124}$. Ancak Yeşilırmak, bu değerlendirmenin her tahkim yeri hukuku bakımından ayrıca yapılması gerektiğini de ifade etmektedir ${ }^{125}$.

Doktrinde genel kabul ise, tahkim öncesi aşama zorunlu tutulduğunda tüketilmesi gerektiği, ihtiyari tutulduğunda ise tahkime başvuru için tahkim öncesi aşamanın tüketilmesinin aranamayacağı, bu hususun taraflara birakıldığı yönündedir ${ }^{126}$. Bu kabule göre, tahkim öncesi aşama zorunlu tutulmuşsa, tüketilmesi gerekir ${ }^{127}$. Tahkim öncesi alternatif uyuşmazlık çözüm yolları ihtiyari tutulmuş ise, ilk kademe olan alternatif uyuşmazlık çözüm yollarının tüketilmemesi, tahkim anlaşmasının geçerliliğini etkilemeyecektir ${ }^{128}$.

Doktrinde Şanlı da, tahkim öncesi aşamanın zorunlu tutulduğu hallerde dahi, tüketilmemesinin tahkim anlaşmasını geçerliliğini etkilemeyeceğini belirtmektedir ${ }^{129}$. Zira, Şanli’ya göre, tahkim öncesi zorunlu aşamanın tüketilmemesi, yalnızca tahkim yoluna başvuruyu engellemekte, tahkim anlaşmasının geçerliliğini etkilememektedir ${ }^{130}$.

Doktrinde Tan Dehmen ise, taraf iradelerinin hiçe sayılarak bağlayıcı sonuçlar doğurmasının engellendiği gerekçesiyle, tahkim öncesi aşamalar tüketilmeden tahkime gidilmesinin yerinde

121 Özbek M, Alternatif Uyuşmazlık Çözümü (3rd edn, Yetkin 2013).) 703.

122 Özbek (n 121) 703.

123 Bkz Ekşi, Tahkim Öncesi (n 72) 46; Kayalı (n 70) 552; ancak görüşü savunan yazar konusunda ilgili kaynaklarda bir açılklk mevcut değildir.

124 Yazar İngiltere ve İsviçre’yi örnek vererek, tahkim yerinin İngiltere ya da İsviçre seçildiği tahkim yargılamalarında, bu hukuklarda dostane çözüm yollarının ön şart olarak kabul edilmesi sebebiyle, tarafların dostane çözüm yollarına başvurması gerektiğini ifade etmiş̧tir. Bkz Ali Yeşilırmak, ICC Tahkim Kuralları ve Uygulaması (1st edn, On İki Levha 2018) 31.

125 Yazar İngiltere ve İsviçre’yi örnek vererek, tahkim yerinin İngiltere ya da İsviçre seçildiği tahkim yargılamalarında, bu hukuklarda dostane çözüm yollarının ön şart olarak kabul edilmesi sebebiyle, tarafların dostane çözüm yollarına başvurması gerektiğini ifade etmiștir. Bkz Yeşilırmak, ICC (n 124) 31.

126 Ekşi, Tahkim Öncesi (n 72) 55; Tan Dehmen (n 74) 463; Şanlı (n 3) 411-413; Erlank (n 80) 46; Kayalı (n 70) 572573; Didem Özdemir Kayalı D, 'Uluslararası Ticari Sözleşmelerde Basamaklı Uyuşmazlık Çözüm Şartları' (2009) Haluk Konuralp’in Anısına Armağan C. I, 499, 514-515.

127 Şanlı (n 3) 411-413; Ekşi, Tahkim Öncesi (n 72) 50; Tan Dehmen (n 74) 464; Erlank (n 80) 46; Kayalı (n 70) 572-573; Özdemir Kayalı (n 126) 514-515.

128 Ekşi, Tahkim Öncesi (n 72) 55; Tan Dehmen (n 74) 459-460; Demirkol and Aküzüm (n 91) 63.

129 Şanlı (n 3) 447.

130 Şanlı (n 3) 447. 
olmadığını belirtmiştir ${ }^{131}$. Tan Dehmen'e göre, böyle bir durumunda, tahkim mahkemesinin, uyuşmazlığın esasına girmeyi reddederek, tahkim öncesi müzakerelerin bitmesini beklemesi yerinde olacaktır ${ }^{132}$. Ancak belirtmek gerekir ki, Tan Dehmen, aşağıda inceleneceği üzere Ekşi’nin aksine, ancak bir itiraz olursa tahkim öncesi aşamaların tüketilip tüketilmediği incelemesi yapılabileceği görüşündedir ${ }^{133}$.

Sarı̈̈z Büyükalp, tahkim öncesi aşama öngörülüp, tüketilmediği durumlarda, hakemlerin yetkisizlik kararı vermesi gerekeceğini, bu nedenle tahkim anlaşmasının icrasının imkânsız hale geleceğini ifade etmektedir ${ }^{134}$.

Doktrinde Ekşi de, tahkim öncesi aşamaların zorunlu tutulup tutulmaması noktasında bir değerlendirme yapmaktadır. Ekşi, tahkim öncesi zorunlu aşamanın tüketilmemiş olması halinde, tahkim anlaşmasının uygulanması için aranan şartın gerçeklememiş olacağını ve bu durumun hakemlerin yetkisine etki edeceğini ifade etmiştir ${ }^{135}$. Ayrıca, tahkim öncesi aşamaların tüketilmesinin hakemlerin yetkisine etki etmesi nedeniyle, Ekşìye göre, kompetenz-kompetenz prensibi gereği, hakemlerin tahkim öncesi aşamaların tüketilip tüketilmediğini re’sen inceleme yetkisi bulunmaktadır ${ }^{136}$.

1996 tarihli İngiliz Tahkim Kanunu, tahkim anlaşmasında, tahkim öncesi başvurulması gereken aşamalar kararlaştırılmışsa, bu aşamalar tüketilmeden tahkime ardından da mahkemeye başvurulup başvurulamayacağını düzenlemiştir. İngiliz Tahkim Kanunu m. 9/ f. 2 hükmünce ${ }^{137}$, taraflar tahkim ya da tahkim öncesi aşamaları tüketmeden mahkemeye başvurmuşlarsa, karşı tarafın 'itirazı üzerine’ mahkeme yargılamayı durduracaktır ${ }^{138}$. İngiliz Kanunlarına göre tahkim öncesi aşamaların tüketilmemesi durumunda, hakem ya da mahkemenin bunu re’sen gözetemeyeceği ifade edilmektedir ${ }^{139}$.

Doktrinde Ekşìnin aksine, Tan Dehmen ${ }^{140}$ gibi, Yeşilova da, tahkim aşamalarının tüketilmemesinin bir itiraz olarak ileri sürülmesi gerektiği kanaatindedir. Yeşilovàya göre, tahkim itirazında olduğu gibi, tahkim öncesi aşamaların tüketilmediği itirazının da bir ilk itiraz olarak belirli bir süreye

131 Tan Dehmen (n 74) 464.

132 Tan Dehmen (n 74) 465.

133 Tan Dehmen (n 74) 465.

134 Sarı̈̈z Büyükalp (n 15) 2054.

135 Ekşi, Tahkim Öncesi (n 72) 50 aynı yönde bkz Tan Dehmen (n 74) 464; Sarı̈z Büyükalp (n 15) 2054.

136 Ekşi, Tahkim Öncesi (n 72) 46.

137 Arbitration Act 1996 article 9/2 "An application may be made notwithstanding that the matter is to be referred to arbitration only after the exhaustion of other dispute resolution procedures." Bkz. http://www.legislation.gov.uk/ukpga/1996/23/ contents (Erișim Tarihi: 03.05.2020)

138 Ekşi, Tahkim Öncesi (n 72) 29-30.

139 Aynı yönde, Tan Dehmen (n 74) 465.

140 Tan Dehmen (n 74) 465. 
bağlı kalınarak ileri sürülmesi gerekir ${ }^{141}$. Bu görüşe göre, mahkemeler, tahkim öncesi aşamaların tüketilmemesini re'sen gözetemeyecektir ${ }^{142}$.

Demir Gökyayla, tahkim öncesi aşamanın zorunlu olarak düzenlendiği hallerde ortaya çıkacak tahkime başvuru engelini, Avrupa İnsan Hakları Mahkemesi’ne (AİHM) başvurmadan önce iç hukuk yollarının tüketilmesi gerekliliğine benzetmektedir ${ }^{143}$. Demir Gökyayla, tahkim öncesi aşamanın tüketilmemesi halinde, davalının tahkime taraf olma yükümlülügünün henüz doğmamış olacağını ve dolayısıyla tahkim davasını hakem heyetinin göremeyeceğini ifade etmektedir ${ }^{144}$.

Demirkol/Aküzüm ise, bir tahkim anlaşması ile Med-Arb anlaşması arasında fark olması gerektiğini, bu nedenle tahkim anlaşmasına tahkim öncesi bir aşama eklenmişse artık bu tahkim öncesi aşamaların tüketilmesi gerektiğini savunmaktadır ${ }^{145}$. Aynı yönde Kayalı da, tahkim öncesi aşamaların zorunlu tutulup tutulmamasına göre bir ayrım yaparak tahkim öncesi aşama zorunlu ise, bu usule uyulmasının gerektiğini ifade etmektedir ${ }^{146}$.

Tüm bu tartışmalarla birlikte, istisnai durumlarda tahkim öncesi aşamanın tüketilmesinde fayda bulunmuyorsa, ön aşamalar tüketilmeden tahkime geçilmesi gerekebilir ${ }^{147}$. Taraflardan biri, tahkim öncesi öngörülen alternatif uyuşmazlık yöntemine başvurmuş ve diğer taraf katılmamışsa, artık bu şartın tahkim yoluna başvuruyu engelleyici niteliğini yitireceği doktrinde genel olarak kabul edilmektedir ${ }^{148}$.

ISTAC Med-Arb Kurallarında da bu durum açık şekilde düzenlenmiş; taraflar arasındaki uyuşmazlı̆̆ı arabuluculuk yöntemiyle çözülmesinin artık olanaksız olması, taraflardan en az birisinin uyuşmazlı̆̆ı arabuluculuk yöntemiyle çözülmesinde haklı bir beklentisinin kalmaması, taraflardan birinin iflası gibi karşı tarafı zor duruma sokabilecek hallerin bulunması ve son olarak taraflardan birinin arabuluculuk talebine karşı diğer tarafin süresi içinde cevap vermemesi veya geçerli bir mazereti olmaksızın arabuluculuk toplantılarına üst üste iki defa katılmaması durumlarında, arabuluculuk süreci sona ermeden önce, doğrudan tahkim davası açabileceği düzenlenmiştir ${ }^{149}$.

141 Yeşilova, Mahkemelerin Yardımı (n 71) 529-530.

142 Yeşilova, Mahkemelerin Yardımı (n 71) 528-530. Aynı yönde, Tan Dehmen (n 74) 465.

143 Demir Gökyayla (n 91) 586.

144 Demir Gökyayla (n 91) 585-586; aynı yönde bkz Demirkol and Aküzüm (n 91) 63-63.

145 Demirkol and Aküzüm (n 91) 62.

146 Kayalı (n 70) 572-573.

147 Demirkol and Aküzüm (n 91) 67.

148 Ekşi, Tahkim Öncesi (n 72) 28; Akıncı, Milletlerarası Tahkim (n 3) 16; Aydın (n 3) 111.

149 ISTAC Med-Arb Kuralları m. 4 f. 7 , "Aşă̆ıdaki hallerde, taraflardan biri arabuluculuk sürecini başlatmadan veya arabuluculuk süreci sona ermeden önce doğrudan tahkim davası açabilir: a. Taraflar arasındaki uyuşmazlı̆̆ın arabuluculuk yöntemiyle çözümlenmesinin olanaksız olduğunu gösteren hallerin bulunması; $b$. Taraflardan en az birisinin uyuşmazlığın arabuluculuk yöntemiyle çözülmesinde açık sebeplerden ötürü haklı bir beklentisinin kalmamış olmasi; c. Taraflardan birinin iflası gibi karşı tarafı zor duruma sokabilecek hallerde, taraflardan birinin doğrudan tahkim sürecini başlatıp ivedî bir karara ulaşmak istemesi; $d$. Taraflardan birinin arabuluculuk talebine karşı tarafin İstanbul Tahkim Merkezi Arabuluculuk Kurallarının 7. maddesi uyarınca süresi içinde cevap vermemesi veya taraflardan birinin geçerli bir mazereti olmaksızın arabuluculuk toplantılarına üst üste iki defa katılmaması." 
Fransız Mahkeme içtihatları incelendiğinde, Fransız hukukunda da, mahkeme veya tahkim öncesi zorunlu aşamalar tüketilmeden, mahkeme ya da tahkime gidilemeyeceği kabul edildiği görülmektedir ${ }^{150}$ Mahkeme öncesi veya tahkim öncesi aşama tüketilmeden, mahkeme veya tahkim yargısına başvurulması durumunda, davalının, tahkim öncesi aşamanın atlandığı itirazında bulunma hakkı doğacaktır ${ }^{151}$.

İsviçre hukukunda ise, İsviçre Federal Mahkemesi bir kararında; tahkim öncesi aşamaların 'ihtiyari olduğuna ilişkin’ bir ifade bulunmaması nedeniyle, bu aşamaların zorunlu olduğuna hükmetmiş ve anlaşmada belirtilen istisnalar hariç, tahkim öncesi aşamalar tüketilmeden, tahkime başvurulamayacağını kabul etmiştir ${ }^{152}$.

Türk hukukunda ise, Yargıtay, tarafların akdettiği tahkim anlaşmasında, tahkim öncesi aşamalar öngörülmüş ise, bu aşamaların tüketilmesi gerektiği görüşündedir ${ }^{153}$.

Kanaatimizce, tahkim öncesi aşamalar, zorunlu tutuldukları durumlarda tüketilmesi gereken basamaklar olarak karşımıza çıkarlar. Bu aşamaların tüketilmemesi, bir tahkime başvuru engeli niteliğinde olup, tahkim anlaşmasının geçerliliğini etkilemeyecektir. Ancak, zorunlu aşamalar tüketilmeden tahkime başvurulması halinde, her ne kadar bu durum hakem heyetinin yetkisine etki edecekse de; hakemlerin yetkisinin kaynağı ve sınırı taraflar olduğu için, taraflar itiraz etmedikçe, hakem heyetinin bu zorunlu aşamaların tüketilip tüketilmediğini re’sen incelenmesine gerek yoktur. Kanaatimizce, taraflar tahkim öncesi aşamaların tüketilmediği itirazında bulunmadıkça, tarafların iradesinin artık bu aşamalardan feragat ettikleri yönünde olduğu kabul edilmelidir.

150 “...Taraflar, sadece zorunlu bir dostane çözüm yolu için bir usul öngörmüşlerse hakim bu itirazı dikkate almalıdır. Tarafların uyuşmazlıkları için sadece dostane çözüm yolunu deneme zorunluluğundan bahseden bir şart böyle bir usul öngörmediğ $i$ için hakimin dostane çözüm yolu itirazına uyması zorunlu değildir... ”Karar için bkz Ebru Ay Chelli, 'Fransız Yargıtay’nın Zorunlu Olmayan Uzlaşma Şartı Tüketilmeden Dava Açılabileceğine İlişkin 29 Nisan 2014 Tarihli Kararının Tercümesi' (2015) 4(2) UTTDER 233, 235 dn. 4.

151 Ekşi, Tahkim Öncesi (n 72) 40.

152 Swiss Federal Court 4A_124/2014, A... SA v. B...SA, 07.07.2014 Bkz <http://www.swissarbitrationdecisions.com/sites/ default/files/7\%20juillet\%202014\%204A\%20124\%202014.pdf> Kararın çevirisi için bkz Baran Yılmaz, 'İsviçre Federal Mahkemesi’nin Tahkim Öncesi Alternatif Uyuşmazlık Çözüm Klozu’nun Bağlayıcılığı Konusundaki 7 Temmuz 2014 Tarihli Kararının Tercümesi' (2015) 4(2) UTTDER 261-284. Karar hakkında değerlendirmeler için bkz Ekşi, Tahkim Öncesi (n 72) 52-53, 90 - 93.

153 Yargıtay 11 HD, 2157/ 6343, 25.05.2009: "Davacı, hırsızlık teminatı içerir sigorta poliçesi ile sigortalı işyerinde 26.03 .2006 tarihinde gerçekleşen hırsızlık sonucu oluşan zararın bir kısmının ödenmediğini ileri sürerek, 24.600,00.-TL'nin davalıdan tahsiline karar verilmesini talep ve dava etmiştir. Davalı vekili, poliçe genel şartı uyarınca uyuşmazlı̆̆ın çözümü için hakem-bilirkişi tayininin gerektiğini ve davacı tazminat talebinin fahiş olduğunu savunarak, davanın reddini istemiştir. Mahkemece, iddia, savunma, benimsenen bilirkişi raporuna ve dosya kapsamına göre, sigortalı işyerinde meydana gelen hırsızlık olayının sigorta poliçe kapsamında olduğu ve taraflar arasındaki "tahkim" sözleșmesinin açıklı ve kesinlik unsuru taşımadığından geçerli bulunmadığı gerekçesiyle 7.368,00 TL’nin davalıdan tahsiline karar verilmiştir. Kararı, davalı vekili temyiz etmiştir. Dava, hırsızlık teminatı içerir işyeri sigorta poliçesinden kaynaklanan tazminat istemine ilişkindir. Taraflar arasındaki akdi ilişkiyi düzenleyen Hirsızlı Sigortası Genel Şartlarının hasar tespitine ilişkin B.3. maddesinde hasar miktarı konusunda tarafların anlaşamamaları halinde uyuşmazhğın hakem bilirkişi aracılığıyla çözümü gerektiği hükme bağlanmış bulunmaktadır. Sözleșmenin bu hükmü, HUMK’nın 287. Maddesinde düzenlenen bir delil sözleşmesi niteliğinde olduğundan tarafları bağlar. Somut olayda, taraflar arasındaki sözleşme hükmünün hakem bilirkişi tayinine ilişkin olmasına rağmen mahkemece, sözleşmenin "tahkim" anlaşması niteliğinde olduğu ve sözleşmenin C.9. maddesindeki yetki anlaşmasının tahkim anlaşmasında bulunması gereken kesinlik unsurunu kaldırdığ gerekçesiyle hakem bilirkişi talebinin reddedilmesi doğru görülmediğinden kararın bozulması gerekmiştir” Bkz Ekşi, Tahkim Öncesi (n 72) 51-52. 
Tahkim öncesi aşamaların tüketilmediği itirazı ancak, davalı tarafından bir dava açma engeli olarak, ilk itiraz biçiminde ileri sürülürse, hakem heyeti bu aşamaların zorunlu aşamalar olarak öngörülüp öngörülmediğinin incelemesini yapmalıdır. Eğer tahkim öncesi ihtiyari aşamalar olduğu açıkça belirtilmemişse veya aşamaların ihtiyari olduğu tereddütsüz bir biçimde anlaşılmıyorsa, tahkim öncesi aşamaların tüketilmesinin taraflar açısından bağlayıcılığı olduğu, başka bir ifadeyle, tahkim öncesi aşamaların zorunlu olduğu kabul edilmelidir. Böyle bir durumunda, tahkim mahkemesi, uyuşmazlığın esasına girmeyi reddetmeli ancak yetkisizlik kararı da vermemelidir. Bu durumda hakemler, tahkim öncesi zorunlu aşamaların tüketilmesi için taraflara süre vermeli, bu konuyu bekletici mesele yaparak tahkim yargılamasını diğer aşamalar tüketilene kadar bekletmeli, bu aşamalar sonucu bir çözüme ulaşılamaması durumunda ise tahkim yargılamasına devam etmelidirler ${ }^{154}$.

Verilen süre içinde, dostane çözüm yoluna davalının başvurmasına da bir engel bulunmamaktadır. Tahkim davasının davacısı ya da davalısı, tahkim öncesi öngörülen alternatif uyuşmazlık yöntemine başvurmuş, ancak diğer taraf katılmamışsa, artık bu şart tahkim yoluna başvuruyu engelleyici niteliğini yitirecektir ${ }^{155}$. Zira, dostane çözüm yollarına başvurmanın zorunlu tutulması, bu müzakerelere katılma zorunluluğunu beraberinde getirmez.

Tüm bu tartışmalarla birlikte, istisnai durumlarda, tahkim öncesi aşamanın tüketilmesinde fayda bulunmuyorsa, ön aşamalar tüketilmeden tahkime geçilmesi gerekebilirr ${ }^{156}$. Taraflardan birinin çaba sarf etmesine karşın diğer tarafın hiçbir şekilde görüşmek istememesi, görüşmelere katılım sağlamaması bu duruma örnek olarak gösterilebiliri ${ }^{157}$. Kaldı ki, doktrinde, Yeşilırmak’ın da ifade ettiği üzere, arabuluculuk ve müzakere Türk hukukunda "taraf iradesine bağl dostane uyuşmazlı çözüm yolları"dır ve Türk hukuku açısından, taraflar bu usullere başvurmaya zorlanamazlar; elbette her tahkim yeri hukuku için bu değerlendirmenin ayrı ayrı yapılması gerekmektedir ${ }^{158}$. Bu görüşe katılmamak da mümkün değildir. Ancak, taraf beyanlarına bağlayıcılık katarak pacta sunt servanda ilkesine bağlı kalmak da gerekmektedir. Bu nedenle, dostane çözüm yollarına başvurmanın kendisi için bağlayıcı olmasını istemeyen taraf, sözleşmeye tahkim öncesi aşamalar yazmamalı ya da bu aşamaların ihtiyari olduğunu belirtmelidir. Tahkim öncesi ihtiyari aşamaların tüketilmemesi ise, tahkime başvuru engeli (tahkimde dava engeli) olarak kabul edilmemelidir.

Doktrinde, Ekşi, tahkim öncesi aşamalar tüketilmeden verilen hakem kararlarının iptal davasına konu olması halinde, zorunlu tahkim öncesi aşamanın tüketilmemiş olmasının "hakemlerin taraflarca kararlaștırlan usule uymaması" ya da "hakemlerin yetkisiz olması veya yetkisini aşması" iptal sebepleri kapsamında değerlendirilerek iptal edilebileceğini, hatta; iptal sebeplerinin kanunda tahdidi olarak sayılması sebebiyle, tahkim öncesi aşamaların tüketilmemesinin de iptal sebepleri arasına eklenmesi gerektiğini ifade etmektedir ${ }^{159}$.

154 Tan Dehmen (n 74) 465.

155 Ekşi, Tahkim Öncesi (n 72) 28; Akıncı, Milletlerarası Tahkim (n 3) 16; Aydın (n 3) 111.

156 Demirkol and Aküzüm (n 91) 67.

157 Akıncı, 'İnşaat sözleşmeleri' (n 120) 138.

158 Yeşilırmak, ICC (n 124) 31.

159 Ekşi, Tahkim Öncesi (n 72) 56. 
İngiliz Yüksek Adalet Mahkemesi’nin 14.11.2012 tarihli karar1 ${ }^{160}$, tahkim öncesi usulün açık ve kesin olmaması sebebiyle, bu usul tüketilmeden verilen kararların iptal edilemeyeceğine karar vermişken, Mahkeme 14.07.2014 tarihli kararında ${ }^{161}$ ise, 'tahkime gidilmeden önce kararlaştırılan aşamaların tüketilmesi gerektiği, aksi durumda kararın iptal edileceğini’ ifade etmiş ancak somut davada, tahkim öncesi aşamaların tüketilmiş olması sebebiyle, iptal talebinin reddine karar vermiştir ${ }^{162}$.

Taylandlı iki farklı şirket ile Singapur’a kayıtlı bir şirket arasında imzalanan bilgi ve bilgisayar teknolojileri servisi sözleşmesinde, tahkim öncesi başvurulması öngörülen aşamalar içeren bir tahkim anlaşması yer almaktadır ${ }^{163}$. Singapur Temyiz Mahkemesi önüne gelen davada verdiği 19.10.2013 tarihli kararında; sözleşmede tahkim öncesi aşamalar düzenlendiğini ve bu aşamalar tüketilmeden yürütülen tahkim yargılaması neticesinde verilen kararın iptaline karar vermiştir ${ }^{164}$.

Bununla birlikte, tahkim anlaşmasında tahkim öncesi aşamalar öngörülmesine karşın, bu aşamalar tüketilmeden verilen tahkim kararının tenfiz davasına konu olması halinde, tahkim öncesi aşamaların tüketilmemesi hakemlerin yetkisine etki ettiğinden, tahkim öncesi aşamalar tüketilmeden verilen hakem kararlarının tenfizinin "hakemlerin taraflarca kararlaştırilan usule uymaması" ya da "hakemlerin yetkisiz olması veya yetkisini aşması"165 nedenleriyle (NYK m. V/f.1/c ve d, MÖHUK $\mathrm{m} .62 / 1 / \mathrm{f}$ ve g) reddedilebileceği de doktrinde ifade edilmektedir ${ }^{166}$.

\section{B. MAHKEME ÖNCESi AŞAMALAR: Devlet Mahkemelerine Başvurudan Önce Kademeli Olarak Tahkim Yargılamasına Gidilmesi Öngörülmüş Anlaşmalar}

Taraflar, birden fazla alternatif uyuşmazlık çözüm yolunu hibrit şekilde sentezleyebileceği gibi, devlet mahkemesi ile birlikte tahkim mahkemesini de yetkili hale getirebilir. Devlet mahkemelerine 'başvurudan önce' kademeli olarak tahkim yargılamasına gidilmesi öngörülen tahkim anlaşmaları, hibrit nitelikleri nedeniyle çalışmamızda ele alınacaktır. Ancak bir öncelik sonralık ilişkisi barındırmayan yetki şartı ve tahkim şartının birlikte yer aldığı tahkim anlaşmaları ve tahkimi, "veya"

160 Wah (Aka Alan Tang) \& Anor v Grant Thornton International Ltd \& Ors [2012] EWHC 3198 (Ch) (14.11.2012) http:// www.bailii.org/ew/cases/EWHC/Ch/2012/3198.html (Erişim Tarihi: 05.06.2020). Karar hakkında değerlendirme için bkz. Ekşi, Tahkim Öncesi (n 72) 59-60.

161 Emirates Trading Agency Llc v Prime Mineral Exports Private Ltd [2014] EWHC 2104 (Comm) (01.07. 2014) http://www. bailii.org/ew/cases/EWHC/Comm/2014/2104.html (Erişim Tarihi: 05.06.2020). Karar hakkında değerlendirme için bkz. Ekşi, Tahkim Öncesi (n 72) 60-64.

162 Ekşi, Tahkim Öncesi (n 72) 59-64.

163 Tahkim şartı metni şu şekildedir: "All disputes arising out of this Cooperation Agreement, which cannot be settled by mediation pursuant to Clause 37.2, shall be finally settled by arbitration to be held in Singapore in the English language under the Singapore International Arbitration Centre Rules ("SIAC Rules")..." bkz. International Research Corp PLC $v$ Lufthansa Systems Asia Pacific Pte Ltd and another [2013] SGCA 55 art. 7.

164 International Research Corp PLC v Lufthansa Systems Asia Pacific Pte Ltd and another [2013] SGCA 55 https://www. supremecourt.gov.sg/docs/default-source/module-document/judgement/2013-sgca-55.pdf (Erişim tarihi 04.06.2020). Karar hakkında değerlendirmeler için bkz. Ekşi, Tahkim Öncesi (n 72) 64-65.

165 Şanlı (n 3) 447; Tan Dehmen (n 74) 465; Aydın (n 3) 111 - 112.

166 Tan Dehmen (n 74) 465; Ekşi, Tahkim Öncesi (n 72) 65. Tahkim öncesi aşamalar zorunlu tutulmasa dahi, tüketilmesi gerektiği görüşü doğrultusunda, tahkim öncesi aşamalar tüketilmeden verilen hakem kararının iptalinin ya da tenfizinin reddinin mümkün olduğu hakkında bkz. Özbek (n 121) 702-703. 
ibaresi ile düzenleyerek, başka bir ifadeyle, tahkim ile devlet mahkemesini sentezlemeden, devlet mahkemesi ile birlikte yetkili kılan tahkim anlaşmaları, hibrit nitelik barındırmamaları nedeniyle çalı̧̧mamız kapsamında incelenmeyecektir.

"Anlaşmazlığın tahkimde çözümlenememesi durumunda devlet mahkemelerinin yetkili olacağını" düzenleyen tahkim anlaşmalarının geçerliliği tartışma konusudur ${ }^{167}$.

İngiliz hukukunda, İngiltere Teknoloji ve İnşaat Mahkemesi tarafından verilen bir kararda, devlet mahkemelerine başvurudan önce kademeli olarak tahkim yargılamasına gidilmesi öngörülmüş olan tahkim anlaşmalarında, sorunun mahkeme öncesi aşamanın zorunlu olup olmadığı noktasında toplandığ ifade edilmiş, mahkeme öncesi aşama tüketilmeden mahkemelere başvurulamayacağına hükmedilmiştir ${ }^{168}$. Doktrinde $E k s ̧ i$ de tahkim öncesi ve mahkeme öncesi aşamaların ihtiyari olduğu durumlarda, tahkim öncesi ya da mahkeme öncesi aşamaların tüketilmemesinin sözleşmenin ihlali sonucunu doğurmayacağını ancak önceki aşamalar zorunlu tutulmuşsa, bu aşamalar tüketilmeden, bir sonraki aşamaya geçilemeyeceğini belirtmiştir ${ }^{169}$.

Türk hukukunda, doktrinde, Demirkol, 'uyuşmazlğın tahkimde çözülememesi durumunda devlet mahkemelerine gidileceği ş̧eklinde düzenlenen tahkim anlaşmalarının bağlayıcı etki doğurmaması sebebi ile geçerli olmayacağını ifade etmektedir ${ }^{170}$.

Yargıtay'ı in ise, mahkeme öncesi tahkim yargılamasının yetkilendirildiği, başka bir ifadeyle, uyuşmazlğ̆ın tahkimde çözümlenememesi halinde devlet mahkemelerinde çözümleneceği” şeklindeki tahkim anlaşmalarına ilişkin farklı kararları mevcuttur. Yargıtay’ın bu türden tahkim anlaşmalarının (1) tarafların tahkim iradelerinde tereddüt oluşması nedeniyle geçersiz olacağına ilişkin kararları ${ }^{171}$ mevcut olmakla birlikte, (2) uyuşmazlık halinde tarafların ortak iradesi ile hakemin seçilememesi veya hakem heyetinin oluşturulamaması halinde, devlet mahkemelerinin yetkili olacağı şeklinde kademeli tahkim anlaşmalarının geçerli kabul edileceğine ilişkin eski tarihli bir kararı da mevcuttur ${ }^{172}$.

Yargıtay'in, "uyuşmazliğın tahkimde çözümlenememesi halinde devlet mahkemelerinde çözümleneceği" şeklinde düzenlenen bir tahkim anlaşmasını geçersiz kabul ettiği, 15 HD, 2198/2758, 22.05.2015

167 Aydemir (n 3) 165-166; Aydın (n 3) 105.

168 Peterborough City Council v Enterprise Managed Services Ltd [2014] EWHC 3193 (TCC) (10 Oct.2014) <http://www. bailii.org/ew/cases/EWHC/TCC/2014/3193.html> Erişim Tarihi: 05.06.2020.

169 Ekşi, Tahkim Öncesi (n 72) 55.

170 Demirkol (n 17) 350.

171 Yargitay 15 HD, 2198/2758, 22.05.2015; Yargitay 15 HD, 769/769, 13.03.2007; Yargitay 11 HD, 1050/3012, 31.03.2003; Yargitay 15 HD, 3203/3914, 17.09.2002; Yargitay 15 HD, 1134/1163, 18.05.1981; Yargitay 15 HD, 247/438, 29.01.1996.

172 Yargitay 15 HD, 3643/4505, 17.12.1987 “...Taraflar arasındaki 04.01.1986 tarihli sözleşmenin 6.4 maddesinde "anlaşmazlılar halinde önce her iki tarafin kabul edeceği bir hakeme başvurulur. 30 gün içinde bir sonuç alınmaması halinde Ankara Mahkemelerini yetkili olduğu kabul edilecektir" hükmü yazılldr. Burada sözü edilen yetki sözcüğü hakemin ya da mahkemenin görevini saptamak için kullanıldı̆̆ı kuşkusuzdur. Davacı, dava dilekçesinde daval ile bir araya gelerek tanınan süre uzatımına rağmen tarafların hakem tayini konusunda anlaşamadıkların bildirmiş olduğundan ve ibraz edilen ihtarname belge ve tutanaklar bu iddiayı doğruladiğından yukarı metni aynen belirtilen sözleşme hükmüne göre tahkim şartının ortadan kalktığının kabulü gerekir. Diğer bir deyimle, tarafların bu açık kabulü karşısında hakem tayininde irade uyumu sağlanamamış olması itibariyle esasa ilişkin uyuşmazlğın mahkemece çözümlenmesi gerekmektedir. O halde davanın bu nedenle reddine karar verilmek üzere hüküm daval yararnna bozulmalıdr’". Bkz Ertekin and Karataş (n 8) 71-72. 
kararı, "Eldeki davada kararlaştırılan tahkim şartında 30 gün içinde bu yolla (tahkim) anlaşma sağlanamaması halinde ihtilafların hallinde İstanbul mahkemeleri ve icra dairelerinin yetkili olacağı belirtildiği, bu şekliyle uyuşmazlı̆̆ı çözümünde tek yetkili olarak hakem heyeti kabul edilmediği, mahkemede de dava açma yetkisi verildiği, tahkim iradesi açık ve kesin olmadiğından geçersizdir. Bu durumda mahkemece tahkim şartının geçersiz olması sebebiyle tahkim ilk itirazı reddedilerek, işin esasına girilip taraf delilleri toplandiktan sonra sonucuna uygun bir karar verilmesi gerekirken bu husus gözden kaçırılarak davanın görev yönünden reddi doğru olmamış, kararın bozulması uygun bulunmuştur" şeklindedir. Kanaatimizce, Yargıtay'ın bu kararında, 'uyuşmazlı̆ıı çözümünde tarafların 30 gün içinde tahkimde anlaşamaması halinde mahkemeye başvuracağı' yönündeki tahkim anlaşmasını geçersiz sayması son derece yerindedir, zira, tahkim tarafların anlaşmaya varacağı bir uyuşmazlık çözüm yöntemi değil, kanunen devlet yargısına alternatif olarak öngörülen özel bir yargılama usulüdür. Tahkim yargılaması neticesinde verilen karar nihai ve kesindir. Tarafların tahkim iradesi açık ve kesin olmalı, uyuşmazlı̆̆ın çözümünde tahkim yolunun seçildiğinde tereddüt bulunmamalıdır.

Yargıtay, mahkeme öncesi hakem-bilirkişiye başvuruyu öngören bir anlaşmadaysa; “...hakem bilirkişiye müracaat etmeyi kararlaştırdikları ve kabul ettikleri, poliçede yer alan hakem bilirkişiye müracaat yolunun tahkim şartı niteliği taşıdığı” gerekçesiyle, tarafların bu ön aşamayı atlayarak mahkemeye başvurması durumunda, davanın usulden reddi değil, taraflara süre verilmesi gerektiği, taraflar bu sürede bir hakem-bilirkişi seçmezlerse, hakem-bilirkişinin mahkemece seçileceği ve hakem-bilirkişi raporunun bekletici mesele yapılacağı yönünde karar vermiştir ${ }^{173}$.

Kanaatimizce, taraf iradelerinin açık olması durumunda "uyuşmazlı̆ın tahkimde çz̈zümlenememesi halinde devlet mahkemelerinde çözümleneceği” şeklinde düzenlenen anlaşmalar geçerli kabul edilmelidir. Çünkü, zaten tahkim yargılaması, tahkim anlaşmasının geçersizliği veya tahkime elverişli olmayan bir konuda düzenlenmiş olması gibi bir nedenle gerçekleşemez ise, tarafların en nihayetinde başvuracakları makam devlet mahkemeleri olacaktır.

Yine, tarafların anlaşması, uyuşmazlığın tahkimde çözümlenememesi halinde çözümleneceği yetkili devlet mahkemesinin belirlenmesine yönelikse, bu anlaşma geçerli kabul edilebilir.

Ancak, tahkimin - devlet yargısına alternatif özel bir yargılama usulü olması, tahkim neticesinde tarafları ve üçüncü kişileri bağlayıcı karar verilecek olması gibi - özellikleri göz ardı edilerek, tahkimin mahkeme öncesi başvurulacak bir uzlaşma makamı gibi belirlendiği tahkim anlaşmaları,

173 Yargitay 17 HD, 20147/8921, 03.06.2014:“...Mahkemece tarafların poliçenin B.2 maddesi ile hakem bilirkişiye müracaat etmeyi kararlaştırdıkları ve kabul ettikleri, poliçede yer alan hakem bilirkişiye müracaat yolunun tahkim şartı niteliği taşıdığı ve cevap süresi içerisinde davalı tarafca ilk itiraz yoluyla ileri sürüldüğü gerekçesiyle davanın usulden reddine karar verilmiş ise de poliçenin B.2 maddesindeki hakem bilirkişiye müracaat koșulu, bir dava koșulu olmayıp HMK’nın 193. maddesinde yer alan bir delil anlașmasıdır. Buna göre hakem-bilirkişi HMK 412.maddesinde tanımlanan hakem sıfatını taşımadığından mahkemece öncelikle taraflara hakem-bilirkişilerini seçmesi için mehil verilmeli şayet taraflar kendilerine verilen mehil içinde hakem-bilirkişilerini seçemedikleri takdirde uyuşmazlğın mahkemece seçilecek bilirkişi tarafindan düzenlenecek rapor dikkate alınarak genel hükümler çerçevesinde davanın sonuçlandırlması gerekirken yazılı şekilde davanın reddine karar verilmesi doğru görülmemiștir...”. 
hukuken bir tahkim anlaşması olma vasfını taşımayacaktır. $\mathrm{Bu}$ anlaşmaların, tahkim anlaşması olduğu kabul edilse dahi, geçersiz bir tahkim anlaşması akdedilmiş olacaktır.

\section{KURUMSAL BIR TAHKIM MERKEZININ BIR BAŞKA KURUMSAL TAHKIM MERKEZININ KURALLARI ILE YETKILENDIRILDIĞi HIBRIT TAHKIM ANLAŞMALARI}

\section{A. KURUMSAL BIR TAHKIM MERKEZININ BIR BAŞKA KURUMSAL TAHKIM MERKEZININ KURALLARI ILE YETKILENDIRILDIĞi TAHKIM ANLAŞMALARININ PATOLOJIK OLARAK NITELENDIRILMESI}

Hibrit tahkim kavramı, bünyesinde bir sentez barındıran tahkim anlaşmaları için kullanılmaktadır. Dolayısıyla hibrit tahkim kavramı, alternatif uyuşmazlık çözüm yöntemleri ile birlikte tahkime atıf yapan tahkim anlaşmaları için kullanıldığı gibi, bir tahkim merkezi ile birlikte farklı bir tahkim merkezi kurallarına atıf yapan tahkim anlaşmaları için de kullanılmaktadır ${ }^{174}$. Hibrit tahkim doktrinde özellikle, ICC gibi bir tahkim merkezi kuralları uygulanarak, başkaca bir tahkim merkezi bünyesinde yürütülen tahkim yargılamaları için kullanılmaktadır ${ }^{175}$. Ancak, bir tahkim merkezi bünyesinde UNCITRAL tahkim kuralları gibi ad hoc tahkim kurallarının uygulanması da hibrit tahkimdir.

Genellikle, taraflar bir tahkim merkezi seçtiklerinde, tahkim yargılamasına uygulanacak kulların da bu tahkim merkezinin kuralları olduğu kabul edilmektedir ${ }^{176}$. Ancak, taraflar aralarında düzenlendikleri tahkim anlaşmasında, tahkimi yürütecek merkezi seçmekle birlikte, tahkim yargılamasına uygulanacak kuralları başkaca bir tahkim merkezinin kuralları olarak kararlaştırabilirler ${ }^{177}$. Birden fazla uyuşmazlık çözüm yolunun kademeli olarak belirlendiği hibrit tahkim anlaşmalarında olduğu gibi, bir kurumsal tahkim merkezi ile birlikte başka bir tahkim merkezi kurallarına atıf yapılan tahkim anlaşmalarında da, tahkim iradesinde bir tereddüt bulunmamaktadır. Ancak, kurumsal bir tahkim merkezi ile birlikte başka bir tahkim merkezi kurallarına atıf yapılan hibrit tahkim anlaşmalarında, uyuşmazlı̆̆ın hangi tahkim kurumu bünyesinde, hangi kurallar çerçevesinde ve hangi sinırlar dâhilinde çözüleceği gibi hususların net olarak belirlenmesi gerekmektedir. Aksi halde, sınırlar net belirlenmediği için, tahkim anlaşması 'uygulanacak kuralların belirsizliği' nedeniyle, patolojik hale gelebilir ${ }^{178}$.

Bu türden tahkim anlaşmalarına, tarafların belirli bir tahkim kurumu seçerek sağladıkları 'kuralların belirliliği avantajı"nı bertaraf ettiği gerekçesiyle eleştiri getirilebilir. Ancak ifade etmek gerekir ki, taraflar kendilerine başkaca bir kurumun tahkim kurallarını seçerek bu faydayı sürdürmektedirler.

174 Davis (n 54) 377; Yudistiana (n 116) 21; Ulrich G Schroeter, 'Ad Hoc or Institutional Arbitration - A Clear-Cut Distinction? A Closer Look at Borderline Cases' (2017) 10(2) Contemporary Asia Arbitration Journal 141, 178.

175 Anthony Cheah Nicholls and Christopher Bloch, 'ICC Hybrid Arbitrations Here to Stay: Singapore Courts' Treatment of ICC Rules Revisions in Articles 1(2) and 6(2)' (2014) 31(3) Journal of International Arbitration 393, 393.

176 Qian and Guo (n 55) 116.

177 Nicholls and Bloch (n 175) 393; Aydın (n 3) 139.

178 Aydin (n 3) 137, 139. 
Hatta denilebilir ki, tarafların, salt kurum seçmeyip, başkaca bir tahkim kurumunun kurallarına atıf yapması, kendileri için daha uygun ve özellikli kuralları inceleyerek seçtikleri anlamına gelecektir. Başka bir ifadeyle, taraflar, 'kuralların belirliliği avantajı’nı seçtikleri diğer tahkim kurumu kuralları ile sağlamaya devam ederler. Bu bakımdan, bu türden bir hibrit tahkimin bir dezavantaj sağlamadığı da söylenebilir.

Ancak, hibrit tahkim anlaşmalarının, NYS m. II/f.3 kapsamında incelendiğinde hem tesirsiz hem de icradan kabiliyetsiz olarak değerlendirilmesi ihtimali vardır. Ancak Singapur Mahkemeleri, aşağıda ayrıntılı olarak inceleyeceğimiz üzere, taraflar arasında "uyuşmazlıklar ICC kuralları çerçevesinde, Singapur'daki tahkim komitesinde çözülür” şeklinde düzenlenen bir tahkim şartına istinaden, tarafların, "Singapur'da bulunan herhangi bir tahkim merkezinde, ICC kuralları çerçevesinde yargılama sürdürülebileceği” sonucuna varmıştır ${ }^{179}$. Ayrıntılı olarak inceleyeceğimiz üzere, bu konuda karar veren İsveç, ABD, Avusturya ve Çin mahkemeleri de hibrit tahkim anlaşmalarını geçerli kabul etmektedir.

Kanaatimizce de, tahkim kurallarının ad hoc şekilde ya da bir tahkim merkezinde başka kurumsal tahkim merkezleri tarafından kullanılması yasaklanmayan bir kurumsal tahkim merkezinin kuralları ${ }^{180}$ uygulanarak tahkim yargılaması yürütülmesini öngören tahkim anlaşmaları, tahkimde belirsizlik yaratmayacak, tartışmaya yer vermeyecek şekilde net bir biçimde düzenlenmişse, geçerli olacaktır. Zira, seçilen tahkim kuralları, bu durumu yasaklamıyorsa, tahkim anlaşmasının geçerliliği tehlikeye düşmez. Kanaatimizce, seçilen tahkim kuralları, bu kuralların ad hoc veya başka kurumsal tahkim merkezleri tarafından kullanılmasını yasaklasa dahi sonuç değişmeyecektir. Ancak, seçilen tahkim merkezinin, seçilen tahkim kurallarını uygulamaması, tahkim anlaşmasının geçerliliğine değil, icra edilebilirliğine etki edecektir.

\section{B. KARŞILAŞTIRMALI HUKUKTA KURUMSAL BIR TAHKIM MERKEZININ BIR BAŞKA TAHKIM MERKEZININ KURALLARI ILE YETKILENDIRILDIĞi TAHKIM ANLAŞMALARINA ILIŞKIN KARARLAR}

'ICC 2012 tahkim kuralları', m.1/f.2 “Divan uyuşmazlıkları kendisi çözmez. Divan, uyuşmazlıkların hakem kurulu tarafından MTO tahkim Kurallarına ("Kurallar”) göre çözülmesini yönetir. Kurallar uyarınca Divan, Kurallara göre verilmiş hakem kararlarının incelenmesi ve onayı dahil olmak üzere tahkim yönetimi konusunda yetkilendirilmiş tek kuruluştur... ${ }^{181}$ ” hükmü ve bu hükmü destekler nitelikte m.6/f.2 "Bu kurallar çerçevesinde yargılamayı kabul eden taraflar, yargılamanın divan

179 Blackaby, Partasides, Redfern and Hunter (n 8) 136 dn 310.

180 Aşağıda ayrıntılı olarak ele alınacağı üzere ICC tahkim kuralları, kuralların ad hoc ya da başkaca kurumsal tahkim merkezleri tarafından kullanılmasını yasaklamaktadır.

181 ICC 2017 Rules 1(2) “The Court does not itself resolve disputes. It administers the resolution of disputes by arbitral tribunals, in accordance with the Rules of Arbitration of the ICC (the "Rules"). The Court is the only body authorized to administer arbitrations under the Rules, including the scrutiny and approval of awards rendered in accordance with the Rules. It draws up its own internal rules, which are set forth in Appendix II (the "Internal Rules")." <https://iccwbo.org/dispute-resolutionservices/arbitration/rules-of-arbitration/\#article_1> Erişim Tarihi: 03.05.2019. Kuralların çevirisi için bkz Yeşilırmak, ICC (n 124) $163 \mathrm{ff}$. 
tarafindan yürütüleceğini kabul etmiş olurlar ${ }^{182 " ~ h u ̈ k m u ̈ ~ i l e, ~ t a r a f l a r ı n, ~ h i b r i t ~ b i r ~ s e c ̧ i m ~ y a p a r a k, ~}$ başka bir makam önünde ICC tahkim kuralları çerçevesinde yargılama yürütmesi kural olarak engellenmek istenmiştir. Belirtmek gerekir ki, 2017 tarihli tahkim kurallarında olduğu gibi, ICC 2021 tahkim kurallarında da bu hükümlerini korumuştur ${ }^{183}$.

Her ne kadar, tahkim yargılama usulünde taraf iradesine üstünlük tanınmakta ve tarafların kendi tahkim kurallarını seçmelerine olanak tanınmakta ise de, ICC 2012 tahkim kuralları, tarafların hibrit prosedürü kabul etmesini, kural olarak, engellemeyi amaçlamaktadır ${ }^{184}$.

Bu kural değişikliği ile, 2012 ve sonrası düzenlenen ICC tahkim kuralları, ad hoc tahkim için ya da başka bir kurumsal tahkim merkezi tarafından yürütülecek yargılamalar için uygulanabilir olmaktan çıkartılmıştır. ICC tahkim kuralları çerçevesinde başka bir merciin tahkimi yönetmesi için yapılan herhangi bir girişim, istenmeyen davalara, önemli zaman ve maliyet kayıplarına yol açabilecektir. Daha da önemlisi, böyle bir girişim sonucu verilecek kararların, icra edilebilirliği ciddi şekilde tehlikeye girebilir. Verilecek kararlar iptal edilebileceği gibi, tenfiz edilmeme ihtimali de doğabilir.

ICC’nin, hibrit tahkimi yasaklar bu hükümleri, Singapur Yüksek Mahkemesi’nin 2009'da, Singapur Uluslararası Tahkim Divanı (SIAC) bünyesinde, ICC 1998 tahkim kuralları çerçevesinde yürüttüğ̈̈ Insigma Technology Co. Ltd. v. Alstom Technology Ltd. kararına karşılık olarak eklediği düşünülmektedir ${ }^{185}$. İlgili hükümlerin hibrit tahkimi engelleme noktasında etkili olup olmayacağı ise tartışmalıdır. Zira, birçok ülke mahkemesinin, önüne gelen bu türden hibrit tahkim anlaşmalarının geçerliliğini aşağıda verilen kararlarda da inceleneceği üzere kabul ettiği görülmektedir.

Ancak yabancı doktrinde bazı yazarlar, ICC tahkim kuralları uyarınca yürütülen ancak ICC bünyesinde olmayan tahkim Mahkemesi tarafindan yönetilen bir tahkim yargilamasinın, artık ICC tahkim olmayacağını,; ICC tahkimin önemi ve faydalarının, sadece Tahkim Kurallarının içeriğinden değil, aynı zamanda ICC'nin Kurallarının nasıl uygulayacağı ve tahkim yargılamalarımın nasıl yönetileceği deneyimi ve teknik bilgisine sahip Mahkemesinden, Sekretaryast ve personelinin kalitesi ile birlikte ICC nezdinde yürütülen tahkime güvenden doğduğunu ifade etmektedir ${ }^{186}$. Yazar, ayrıca, kurumsal tahkim merkezi kurallarının, ad hoc tahkim için uygun olmadığını; taraflarca, ad hoc tahkim için özel olarak tasarlanmış UNCITRAL Model Kanun gibi kuralların tercih edilmesinin daha yerinde olacağını savunmaktadır ${ }^{187}$. Her tahkim merkezi kuralının, o kurumun yapısı, deneyimi ve özellikleri için özel olarak tasarlandığını ve bu nedenle, başkaca kurum tarafından uygulanması yerine, taraflarca,

182 ICC 2017 Rules 6(2) "By agreeing to arbitration under the Rules, the parties have accepted that the arbitration shall be administered by the Court." <https://iccwbo.org/dispute-resolution-services/arbitration/rules-of-arbitration/\#article_6> Erişim Tarihi: 03.05.2019.

183 ICC 2021 Tahkim kuralları ile 2017 tahkim kurallarının karşılaştırması içib bkz https://iccwbo.org/publication/iccarbitration-rules-2017-and-2021-compared-version/?dm=bypass (ErişimTarihi: 20.01.21)

184 Nicholls and Bloch (n 175) 393; Jason Fry, 'HKL Group Ltd. v. Rizq International Holdings Pte. Ltd. and HKL Group Co. Ltd. v. Rizq International Holdings Pte. Ltd.' (2013) 30(4) Journal of International Arbitration 453, 460.

185 Nicholls and Bloch (n 175) 394.

186 Nicholls and Bloch (n 175) 397; Fry (n 184) 460.

187 Nicholls and Bloch (n 175) 397. 
kurumların kendi kurallarının tercih edilmesinin, tahkim yargılamasının yürütülmesi açısından daha işlevsel olacağını ifade etmektedir ${ }^{188}$.

\section{Insigma Technology Co Ltd v Alstom Technology Ltd Kararı ${ }^{189}$}

Singapur Mahkemeleri önüne gelen bir davada, taraflar "herhangi bir ihtilaf halinde uyuşmazlkklarının Singapur Uluslararası Tahkim Divanı (SIAC) önünde, ICC tahkim kuralları çerçevesinde çözüleceği”ne ilişkin bir tahkim şarti ${ }^{190}$ kabul etmişlerdir ${ }^{191}$.

Uyuşmazlık ortaya çıtıktan sonra, Alstom Teknoloji Limited Şirketi, SIAC’ın ön kabulü ile ICCParis'ten, yargılamanın SIAC tesislerinde gerçekleştirileceği bir ICC tahkim başvurusunda bulunmuştur ${ }^{192}$. Insigma Teknoloji Limited Şirketi ise, tarafların, SIAC tarafından - ICC kuralları çerçevesinde yürütülecek bir tahkim noktasında anlaştıklarını ve böyle bir anlaşma gerçekleştirmelerinin nedenin de, SIAC’’n düşük tahkim ücretlerinden yararlanmak olduğunu ifade ederek, itirazda bulunmuştur ${ }^{193}$.

Alstom Teknoloji Limited Şirketi, tarafların hakemlerini seçmesine karşın henüz ICC tarafından tahkim mahkemesi oluşturulmamışken, SIAC ile irtibata geçerek, uyuşmazlıkları konusunda yargı yetkisini kabul edip etmediklerini danışmışlardır ${ }^{194}$. SIAC, her ne kadar tahkim anlaşmasında iki farklı tahkim kuruma atıf yapılmışsa da, ICC tahkime üstünlük tanınması gerektiğini ve SIAC bünyesinde, ICC kuralları çerçevesinde bir tahkim gerçekleştirebileceğini ifade etmiştir ${ }^{195}$. Tarafların kararı ile, ICC’de yürütülen tahkimden vazgeçilmiştir ${ }^{196}$. Ardından, SIAC bünyesinde kurulan tahkim mahkemesi, ICC 1998 tahkim kuralları çerçevesinde tahkim yargılamasının yürütülmesi gerektiğini ifade etmiştir ${ }^{197}$ ve Uluslararası Singapur Tahkim Merkezi SIAC tarafından da, tahkim mahkemesinin bu yaklaşımı kabul edilmiştir.

Insigma Teknoloji Limited Şirketi, tahkim yargılamasında, bir ön sorun olarak, tahkim anlaşmasının 'hem ICC hem de SIAC’a atıf yapması' nedeniyle geçersiz olduğunu ileri sürmüştür ${ }^{198}$. Kurulan tahkim

188 Nicholls and Bloch (n 175) 397-398.

189 Insigma Technology Co Ltd v Alstom Technology Ltd [2008] SGHC $134<$ https://www.supremecourt.gov.sg/docs/defaultsource/module-document/judgement/2008-sghc-134.pdf> Erişim Tarihi: 01.04.2020.

190 “...Any and all such disputes shall be finally resolved by arbitration before the Singapore International Arbitration Centre in accordance with the Rules of Arbitration of the International Chamber of Commerce then in effect and the proceedings shall take place in Singapore and the official language shall be English." Bkz Insigma Technology Co Ltd v Alstom Technology Ltd [2008] SGHC 134 article 3 (c).

191 Nicholls and Bloch (n 175) 394; Klaus Peter Berger, 'Institutional Arbitration: Harmony, Disharmony and the "Party Autonomy Paradox” (XI Conferencia Internacional Hugo Grocio de Arbitraje, Madrid 2018), 10-11.

192 Nicholls and Bloch (n 175) 394.

193 Nicholls and Bloch (n 175) 394-395.

194 Nicholls and Bloch (n 175) 395.

195 Nicholls and Bloch (n 175) 395.

196 Nicholls and Bloch (n 175) 395.

197 Nicholls and Bloch (n 175) 395.

198 Nicholls and Bloch (n 175) 395. 
mahkemesi ise, tahkim anlaşmasının geçerli olduğuna karar vermiştir ${ }^{199}$. SIAC, mutatis mutandis ${ }^{200}$ prensipleri çerçevesinde, kendi organlarının ICC muadillerini belirleyerek ICC Kuralları uyarınca bir dava yürütülebildiğinden, tahkim anlaşmasının tatbiki imkânsız olmadığını ifade etmiştir ${ }^{201}$.

Insigma Teknoloji Limited Şirketi, mahkemenin bu kararına itiraz etmiştir ${ }^{202}$. Singapur Yüksek Mahkemesi; bu itiraz neticesinde, tarafların, "ICC Kuralları uygulanarak SIAC tarafından yönetilecek bir 'hibrit ad hoc tahkim' için anlaştı̆̆ına" hükmetmiştir ${ }^{203}$. Singapur Yüksek Mahkemesi, tahkim anlaşmasını 'hybrid ad hoc tahkim' olarak nitelendirmiştir ${ }^{204}$. Yüksek mahkeme, tarafların iradelerinin, uyuşmazlıklarını davadan ziyade tahkim yoluyla çözme noktasında açık olduğu sürece, taraf iradelerinin kurumsal çıkarları gölgede bırakması gerektiğini ifade edilmiştir.

Ancak, ICC kuralları uygulanarak SIAC bünyesinde yürütülen yargılama neticesinde verilen kararın tanınması ve tenfizi, 2011 yılında, Çin Halk Cumhuriyeti Hangzhou (Intermediate) Halk Mahkemesi tarafından reddedilmiştir ${ }^{205}$. Reddin sebebi, SIAC tarafından yürütülen tahkim prosedüründe, tahkim mahkemesinin oluşturulma sürecinin tahkim anlaşmasına uygun olmaması ve hakemlerin ICC kurallarından ziyade SIAC kurallarına göre atanması olarak ifade edilmiştir ${ }^{206}$. Görüldüğü üzere, hakem kararının tenfizinin reddi, hibrit tahkim anlaşmasının geçersizliği değil, SIAC’ın ICC kurallarını uygularken hakem seçiminde yaptığı hatalı uygulamadır.

\section{HKL Group Co. Ltd. V. Rizq International Holdings Pte. Ltd. Kararları207}

ICC tahkim kurallarının 2012 değişikliğinden sonra, HKL Group Co. Ltd. V. Rizq International Holdings Pte. Ltd. arasında kurulan sözleşmede, "ICC kuralları çerçevesinde, Singapur'daki tahkim komitesi $^{208}$ " ifadesi ile kurdukları tahkim şartının geçerliliği ihtilafa yol açmıştır. Bu ihtilaf nedeniyle, taraflar, 2013 yılında Singapur Yüksek Mahkemesine başvurmuşlardır ${ }^{209}$.

199 Nicholls and Bloch (n 175) 395.

200 Bir yerden yasa ithal edildiğinde o yasada değişiklikler yapmak gerekebilir. Bu değişiklikler iki ülke arasındaki kültürel farklar ya da başka nedenler dolayısıyla kaçınılmaz olabilir. Bir yasa için mutatis mutandis uygulanabilir deniliyorsa o yasanın olduğu gibi uygulanamayacağı, ancak ve ancak uyum sağlamaya yönelik değişiklikler yapıldıktan sonra uygulanabileceği, yaşama geçirilebileceği anlatılmak istenir.

201 Nicholls and Bloch (n 175) 395.

202 Insigma Technology Co Ltd v Alstom Technology Ltd [2008] SGHC 134 Article 25.

203 Insigma Technology Co Ltd v Alstom Technology Ltd [2008] SGHC 134 Article 25.

204 Schroeter (n 174) 180.

205 Nicholls and Bloch (n 175) 396.

206 Insigma Technology Co Ltd v Alstom Technology Ltd [2008] SGHC 134 Article 31 "There is also no reason the arbitration cannot in fact be administered by the SIAC in accordance with the ICC Rules.". Bkz Nicholls and Bloch (n 175$) 396$.

207 HKL Group Co. Ltd. v. Rizq International Holdings Pte. Ltd. [2013] SGHCR 5, karar metni için bkz <https://www. supremecourt.gov.sg/docs/default-source/module-document/judgement/2013-sghcr-5.pdf> Erişim Tarihi: 01.04.2020.

208 Tahkim şartı İngilizce metinde şu şekildedir: "Arbitration committee at Singapore under the rules of International Chamber of Commerce."

209 HKL Group Co. Ltd. v. Rizq International Holdings Pte. Ltd. [2013] SGHCR 5, karar metni için bkz <https://www. supremecourt.gov.sg/docs/default-source/module-document/judgement/2013-sghcr-5.pdf> Erişim Tarihi: 01.04.2020. 
Rizq International Holdings Pte. Ltd., tahkim şartı kusurlu olsa dahi, tarafların tahkim iradesinin açık olduğunu, uyuşmazlığın çözümünde, tarafların, ICC kurallarınca SIAC bünyesinde yürütülecek ad hoc bir tahkim için yönlendirebileceğini beyan etmiştir ${ }^{210}$. HKL Group Co. Ltd. ise, tahkim sözleşmesinin tatbiki imkânsız derecede kusurlu olduğunu ve "Singapur'daki tahkim komitesi" ifadesiyle, mevcut olmayan bir tahkim kurumuna atıf yapıldığını iddia etmiştir ${ }^{211}$.

Yüksek Mahkeme, öncelikle, Singapur'da “tahkim komitesi” adını taşıyan bir kurum olmaması sebebiyle, tahkim şartının patolojik olarak nitelendirilip nitelendirilmeyeceğini, mevcut olmayan bir tahkim kurumuna atıf yapılmış olması bakımından incelemiştir ${ }^{212}$. Yüksek Mahkeme, SIAC tarafından, ICC Kuralları uygulanarak tahkim yürütülmesinin olağan bir davranış olmaması nedeniyle, tahkim şartında yer alan "tahkim komitesi" terimindeki benzerliklere ve "Singapur Uluslararası Tahkim Merkezi”nde geçen “tahkim merkezi” kelimelerine rağmen; tahkim şartının SIAC’a atıfta bulunduğu sonucuna varılamayacağına karar vermiştir ${ }^{213}$. Mahkeme yine de, tahkim şartının (1) tarafların herhangi bir anlaşmazlığı tahkim yoluyla çözme niyetlerini açıkça ortaya koyması, (2) bir anlaşmazlık çıktığında tahkime gidilmesine zorunlu sonuçlar bağlaması, (3) tahkim yeri olarak Singapur'u belirtmesi ve son olarak, (4) tahkimin belirli bir kurallar dizisi - ICC kuralları - çerçevesinde yönetilmesini sağlaması nedenleriyle, geçerli ve icra edilebilir olduğu kanaatine varmıştır ${ }^{214}$. Singapur Yüksek Mahkemesi, tahkim şartının Singapur Milletlerarası Tahkim Kanunu ${ }^{215}$ çerçevesince de geçersiz, yok ya da icrası imkânsız olmadığını belirtmiştir ${ }^{216}$. Bu şartlar altında, Yüksek Mahkeme, seçilen tahkim kurumu belirsiz olsa dahi, tahkim iradelerinin açı olması sebebiyle, tarafların, Singapur'da ICC kurallarını uygulayarak uyuşmazlıklarını çözecek herhangi bir tahkim merkezini seçme noktasında serbest olduğu kanaatini beyan etmiştir ${ }^{217}$.

Özetle, verilen ilk kararda, Singapur Yüksek Mahkemesi, uyuşmazlığın hibrit tahkim şeklinde ICC kuralları uygulanarak SIAC veya başkaca bir kurumsal tahkim merkezi bünyesinde görülmesi konusunda bir geçersizlik bulunmadığ 1 kanaatindedir ${ }^{218}$. Ancak Mahkeme, hibrit tahkimin pratikte oluşturacağ 1 zorluklardan kaçınmak için, taraflara, (1) aralarında yeni bir anlaşma yaparak doğrudan

210 HKL Group Co. Ltd. v. Rizq International Holdings Pte. Ltd. [2013] SGHCR 5 article 9.

211 HKL Group Co. Ltd. v. Rizq International Holdings Pte. Ltd. [2013] SGHCR 5 article 11 "In response, HKL argued that the arbitration clause was so defective as to be inoperable because it refers to a non-existent entity..".

212 HKL Group Co. Ltd. v. Rizq International Holdings Pte. Ltd. [2013] SGHCR 5 article 2.

213 HKL Group Co. Ltd. v. Rizq International Holdings Pte. Ltd. [2013] SGHCR 5 article 26.

214 HKL Group Co. Ltd. v. Rizq International Holdings Pte. Ltd. [2013] SGHCR 5 article 27 "Nonetheless, in my view, the arbitration clause is operative and workable for the following reasons. First, it clearly evinces the intention of the parties to resolve any dispute by arbitration. Second, it provides for mandatory consequences in that if a dispute arises, the matter has to be referred to arbitration. Third, it states the place of the arbitration, namely, Singapore. Fourth, it provides that the arbitration is to be governed by a particular set of rules, namely, the ICC rules.".

215 International Arbitration Act rev. ed. 2002 bkz <https://sso.agc.gov.sg/Act/IAA1994>

216 HKL Group Co. Ltd. v. Rizq International Holdings Pte. Ltd. [2013] SGHCR 5 article 29.

217 Her ne kadar böyle bir tahkim merkezi bulmak zor olsa da önceki davalarda, SIAC’’n hibrit tahkimleri kabul ettiği bilinmektedir. Bkz HKL Group Co. Ltd. v. Rizq International Holdings Pte. Ltd. [2013] SGHCR 5 article 28.

218 HKL Group Co. Ltd. v. Rizq International Holdings Pte. Ltd. [2013] SGHCR 5 article 37-38; Bkz Fry (n 184) 455. 
bir tahkim kurumu seçmek ya da (2) ICC kuralları uygulayarak yargılama yapacak bir tahkim kurumunu kabul etmek gibi iki farklı seçenek sunmuştur ${ }^{219}$.

Görüldüğü gibi, ICC tahkim kurallarının 2012 değişikliğinden sonra da Singapur Yüksek Mahkemesinde açılan HKL Group Co. Ltd. V. International Holdings Pte. Ltd. davasında, mahkeme, hibrit tahkim sözleşmelerinin geçerliliği yönündeki kararını sürdürmeye devam etmiştir.

Ardından, Mahkeme, aynı davaya ilişkin ikinci karar $^{220}{ }^{2 n d a}$ da tarafların irade serbestilerine ve sözleşme yapma özgürlüklerine vurgu yapmaya devam etmiştir ${ }^{221}$. Mahkeme, anlaşmazlık çözümüne giden yolun patolojinin yarattığı engellerle dolu olduğunu, ancak, tahkim iradeleri açık olduğu sürece, patolojinin çözümü için taraflara daha fazla seçenek sunulması gerektiğini ifade etmiştir ${ }^{222}$. Bu kapsamda, Yüksek Mahkeme, tarafların "tahkim komitesi” ifadesinin herhangi bir kuruma direkt atfının kabul edilemediği durumlarda, - yani seçilen kurumsal tahkim merkezinin mevcut ya da belirli olmaması durumlarında - tarafların anlaşmazlığı çözmedeki seçeneklerini sınırlandırır bir yorum getirilmesinin gereksiz olduğunu, taraflara daha fazla seçenek sunulması gerektiğini hükmüne eklemiştir ${ }^{223}$.

Ayrıca mahkeme, her ne kadar, ICC tahkim kurallarının m.1/f.2 nedeniyle, ICC'nin, ICC tahkimlerini yönetme yetkisinin tek başına kendi uhdesinde olduğunu iddia etse de, ilgili hükmün, tarafların Singapur'da bir ICC tahkim konusunda anlaşmalarını ve mahkemenin bu şartı geçerli kılmasını engellemeyeceğine vurgu yapmıştır ${ }^{224}$.

Bununla birlikte, Yüksek Mahkeme, hibrit tahkim yolunun açık bırakılmasının yalnızca patolojik tahkim şartını geçerli hale getirmek için çözümün bir parçası olarak sunulduğunu, hibrit tahkimi yasal olarak onaylamak anlamına gelmeyeceğini, tarafların hibrit tahkimden kaçınması gerektiğini de kararına eklemiştir 225 .

Karardan anlaşıldığ üzere; taraflar mahkemenin bir önceki kararındaki önerisine uyarak, hibrit tahkimden vazgeçmiş ve doğrudan SIAC tahkime gitme noktasında anlaşmışlardır²6.

Singapur Yüksek Mahkemesi, Insigma Technology Co. Ltd. V. Alstom Technology Ltd. kararında, doğrudan hibrit tahkimin geçerliliğini tartışarak, hibrit tahkim anlaşmalarını geçerli kabul etmiş; HKL Group Co. Ltd. V. International Holdings Pte. Ltd. kararında ise, ICC tahkim kuralları

219 HKL Group Co. Ltd. v. Rizq International Holdings Pte. Ltd. [2013] SGHCR 5 article 37-38; Bkz Fry (n 184) 455.

220 HKL Group Co. Ltd. v. Rizq International Holdings Pte. Ltd. [2013] SGHCR 8, Karar metni için bkz <https://www. supremecourt.gov.sg/docs/default-source/module-document/judgement/2013-sghcr-8.pdf> Erişim Tarihi: 01.04.2020.

221 HKL Group Co. Ltd. v. Rizq International Holdings Pte. Ltd. [2013] SGHCR 8 article 1.

222 HKL Group Co. Ltd. v. Rizq International Holdings Pte. Ltd. [2013] SGHCR 8 article 9.

223 HKL Group Co. Ltd. v. Rizq International Holdings Pte. Ltd. [2013] SGHCR 8 article 9.

224 HKL Group Co. Ltd. v. Rizq International Holdings Pte. Ltd. [2013] SGHCR 8 article 10.

225 HKL Group Co. Ltd. v. Rizq International Holdings Pte. Ltd. [2013] SGHCR 8 article 11.

226 HKL Group Co. Ltd. v. Rizq International Holdings Pte. Ltd. [2013] SGHCR 8 m. 4. 
uygulanarak, belirli olmayan bir tahkim merkezi bünyesinde gerçekleştirilecek tahkim şartının geçerliliği değerlendirilmiş ve yine anlaşmanın geçerli olacağı kanaatine varmıştır 227 .

\section{INVISTA Technologies Sàrl vs. Zhejiang Yisheng Petrochemical Co. Ltd. ${ }^{228}$}

Çin Mahkemeleri önüne gelen bir davada da, taraflar aralarında 'CIETAC bünyesinde UNCITRAL kurallarınca bir tahkim ${ }^{229}$ öngörmüşlerdir ${ }^{230}$. 2012 yılında, INVISTA Technologies Sàrl, Yisheg Co., CIETAC bünyesinde UNCITRAL kuralları uyarınca bir tahkim yargılaması başlatmış, ancak, Yisheng Co., tahkim anlaşmasının geçersizliği itirazı ile Çin Devlet Mahkemelerine başvurmuş ve tahkim mahkemesinin yetkisine itiraz etmiştir ${ }^{231}$.

Çin Tahkim Kanunu m. $16^{232}$ ve m. $18^{233}$, tahkim anlaşmalarının geçerli olabilmesi için, taraflarca bir tahkim merkezinin seçilmesini şart koşmaktadır; başka bir ifadeyle, ad hoc bir tahkim öngörülmesi, tahkim anlaşmalarının geçersizliği ile sonuçlanır ${ }^{234}$. Yisheng Co., aralarındaki tahkim anlaşmasında, (1) Tahkim Kanunu'nun bahsettiği anlamda bir kurumsal tahkim merkezine atıf yapılmadığı, (2) UNCITRAL Tahkim Kurallarını seçerek, tipik bir ad hoc tahkim anlaşması gerçekleştirildiği ve (3) hakemlerce baştan itibaren izlenen prosedürün ad hoc tahkime uygun şekilde ilerlediği gerekçeleri ile, tahkim anlaşmasının geçersiz olduğunu iddia etmiştir 235 .

Mahkeme, kararında, yukarıdaki üç gerekçeden ilkine yoğunlaşarak, tahkim şartının gerçekten CIETAC’ta gerçekleştirilecek ad hoc bir UNCITRAL tahkimi ihtiva edip etmediğini ele almıştır ve tahkim şartının kurumsal bir tahkimi öngördüğü sonucuna varmıştır. Ancak mahkeme kurumsal bir tahkimin mevcudiyetine karar vermesine karşın, tahkim şartının hibrit nitelikli olması noktasında

227 Fry (n 184) 459.

$228 \mathrm{https} / /$ cgc.law.stanford.edu/wp-content/uploads/sites/2/2016/11/B-and-R-TC6-English.pdf

229 "[t]he arbitration shall take place at China International Economic Trade Arbitration Centre [sic] (CIETAC), Beijing, PR China and shall be settled according to the UNCITRAL Arbitration Rules as at present in force" Bkz. James Rogers, Cao Lijun and Matthew Townsend, 'Legality of 'Hybrid' Arbitration Clauses Upheld in China' (2014), 6(3) Asian Dispute Review 146, 147; Jane Willems, Chapter 38: The Arbitrator's Jurisdiction at Risk: The Case of Hybrid and Asymmetrical Arbitration Agreements in Pierre A. Karrer, Patricia Shaughnessy, Sherlin Tung (eds), The Powers and Duties of an Arbitrator, Liber Amicorum Pierre A. Karrer (Kluwer Law International BV 2017) 408.

230 Rogers, Lijun and Townsend (229) 147; Willems (229) 408.

231 Rogers, Lijun and Townsend (229) 147; Willems (229) 408.

232 Arbitration Law of the People's Republic of China art. 16 "An agreement for arbitration shall include the arbitration clauses stipulated in the contracts or other written agreements for arbitration reached before or after a dispute occurs. An arbitration agreement shall contain the following: 1. The expression of application for arbitration. 2. Matters for arbitration. 3. The arbitration commission chosen." http://english.mofcom.gov.cn/article/policyrelease/ Businessregulations/201312/201.312.00432698.shtml (Erişim Tarihi: 17.12.2020).

233 Arbitration Law of the People's Republic of China art. 18 "Whereas an agreement for arbitration fails to specify or specify clearly matters concerning arbitration or the choice of arbitration commission, parties concerned may conclude a supplementary agreement. If a supplementary agreement cannot be reached, the agreement for arbitration is invalid." http:// english.mofcom.gov.cn/article/policyrelease/Businessregulations/201312/201.312.00432698.shtml (Erişim Tarihi: 17.12.2020).

234 Rogers, Lijun and Townsend (229) 146, 147; Giovanni Pisacane, Lea Murphy and Calvin Zhang, Arbitration in China Rules \& Perspectives (1st edn, Springer 2016) 13, 56; Moses (n 60) 9.

235 Rogers, Lijun and Townsend (229) 148. 
bir yorumda bulunmamıştır. Sonuç olarak, Çin Mahkemeleri, Yisheng Co.'nin tahkim anlaşmasının geçersiz olduğuna ilişkin itirazını reddetmiştir ${ }^{236}$.

Belirtmek gerekir ki, Çin Mahkemeleri, bu yaklaşımını, önüne gelen diğer uyuşmazlıklarda da korumuş, başkaca bir tahkim merkezi bünyesinde uygulanmak üzere UNCITRAL kurallarının ve hatta ICC kurallarının seçildiği tahkim anlaşmalarını da geçerli kabul ettiği kararlar vermiştir ${ }^{237}$. Dolayısıyla denilebilir ki, Çin Hukuku bakımından, hibrit tahkim anlaşmaları geçerli kabul edilmektedir $^{238}$.

\section{Exxon Neftegas Ltd. v. WorleyParsons Ltd. Kararı 239}

New York Yüksek Mahkemesi de tarafların, aralarında akdettikleri sözleşmenin 10.3 maddesine; American Arbitration Association (AAA) bünyesinde, ICC kuralları çerçevesinde yürütülecek bir tahkim' şartı koyarak, hibrit bir tahkim anlaşması akdettiği bir anlaşmayı geçerli kabul etmiştir ${ }^{240}$. Tarafların aralarındaki tahkim anlaşmasına rağmen, Exxon Neftegas Ltd. devlet mahkemesinde dava açmıştır ${ }^{241}$. New York Mahkemesi de, Singapur mahkemelerinde olduğu gibi, bu tip hibrit bir tahkim anlaşmalarını geçerli kabul etmiştir ${ }^{242}$.

Ancak Singapur Mahkemesi'nin Insigma Teknoloji kararının aksine, New York Yüksek Mahkemesi, tahkimin ad hoc ya da kurumsal olması noktasında bir değerlendirme yapmamıştır ${ }^{243}$. Yüksek Mahkeme, tahkim anlaşmasının geçerli olduğuna hükmettikten sonra, AAA’nın tahkim yargılamasını ICC tahkim kuralları bünyesinde gerçekleştirmeyi reddetmesi ya da gerçekleştirememesi durumunda, "ICC tahkim kuralları uygulanır" hükmünün anlaşmadan ayrılacağını ve tahkim yargılamasının artık AAA tahkim kuralları bünyesinde yürütüleceğine hükmetmiştir ${ }^{244}$.

236 Rogers, Lijun and Townsend (229) 148; Willems (229) 408.

237 UNCITRAL kurallarının seçildiği bir tahkim anlaşmasının geçerli kabul edildiğine ilişkin; Shanghai 2nd Intermediate People's Court, 23.01.2015, [2013], Hu Er Zhong Min Ren (zhongcai )No.1 Yayınlanmamış karar bkz. Willems (229) 409. SIAC bünyesinde ICC kuralları uygulanmasına ilişkin bir tahkim anlaşmasının geçerli kabul edildiğine ilişkin; Top Gains Minerals Macao Commercial Offshore Ltd. v. TL Resource Pte Ltd. [2015], HKCFI 2101; HCMP 1622/2015 (18.11.2015) bkz. Willems (229) 406.

238 Willems (229) 409-410.

239 Exxon Neftegas Ltd. v. WorleyParsons Ltd., New York Supreme Court [2014] WL 9873313, case number 654405/2013. <https:/www.kirkland.com/news/in-the-news/2015/05/exxon-worleyparsons-agree-to-78m-oil-rig-settlemen> Erişim Tarihi: 23.09 .2020 .

240 "10.3 Dispute Resolution. The parties agree to resolve all differences arising out of or relating to this Agreement or any Order through binding arbitration before three arbitrators pursuant to the Arbitration Rules of the International Chamber of Commerce (ICC Rules). The place of arbitration shall be Houston, Texas, and the language of the arbitration shall be English. The American Arbitration Association shall administer the arbitration, and also act as the appointing authority when the ICC Arbitration Rules call for an appointing authority to act...” Bkz <https://iapps.courts.state.ny.us/nyscef/ ViewDocument?docIndex=HVSw5zvWEWH73xIQdMrTxQ==> Erişim tarihi:23.09.2020; Berger (n 191) 13.

241 Schroeter (n 174) 181.

242 Berger (n 191) 19.

243 Schroeter (n 174) 181.

$244 \mathrm{Bkz}<$ https://iapps.courts.state.ny.us/nyscef/ViewDocument?docIndex=6vY9seJhoreau8MhwAr9Jw==> Erişim tarihi:23.09.2020. 
New York Yüksek Mahkemesi verdiği karar ile, tahkimi yönetmesi için seçilen tahkim kurumuna, başka bir kurumun kuralları uyarınca bir tahkim yürütmeyi kabul edip etmemek konusunda karar hakkı tanımışıı ${ }^{245}$. Schroeter New York Yüksek mahkemesinin verdiği bu karar ile, tahkim yargılamasında kural seçiminden ziyade, kurum seçimine üstünlük tanıdığını ifade etmektedir ${ }^{246}$.

Bu kararı yorumlamak gerekirse; AAA'nın, ICC tahkim kuralları çerçevesinde tahkim yargılaması yürütmek istememesi durumunda, tahkim anlaşması yine geçerli olacak, ancak AAA nezdinde, AAA kuralları çerçevesinde tahkim yargılaması yürütülecektir.

\section{I.M. Baldprim S.R.L. vs. The Government of Russian Federation Kararı ${ }^{247}$}

İsveç Svea Temyiz Mahkemesi de, "Stockholm Ticaret ve Sanayi Odası (SCC) tarafindan ICC Kuralları uygulanarak yürütülmesi konusunda anlaşılan" bir hibrit tahkim şartını geçerli kabul etmiştir. Moldovyalı şirket I.M. Badprim S.R.L. (Baldprim) ve Rusya Federasyonu Custom Office, aralarında çıkacak uyuşmazlıklara, SCC bünyesinde ICC tahkim kuralları uygulanmasını kararlaştırılarak, hibrit bir tahkim anlaşması gerçekleştirmişlerdir. Taraflardan Baldprim, aralarında çıkan uyuşmazlık neticesinde, Rusya Federasyonu ve Rusya Federasyonu Custom Office aleyhine tahkim yargilamasina başvurmuştur ve Rusya Federasyonu Hükümeti, hakemlerin yetkisine itiraz etmiştir. Tahkim mahkemesi bu itiraz neticesinde kendini yetkili kabul etmiş, yargılamayı tamamlayarak bir hüküm tesis etmiştir. Rusya Federasyonu Hükümeti, verilen kararın iptali için Svea Temyiz Mahkemesine başvurmuştur.

Rusya Federasyonu Hükümeti, Rus Hukuku altında Custom Office ile Hükümetin ayrı tüzel kişilikleri olduğunu, Badprim ile sözleşme imzalayanın Custom Office olduğunu, dolayısıyla verilen kararın geçerli bir tahkim anlaşmasına dayanmadığını iddia etmiştir. Rusya Federasyonu Hükümeti, Svea Mahkemesi’nin, Rusya Federasyonu Hükümeti’nin tahkim anlaşmasına taraf olduğu sonucuna varması durumunda da tahkim anlaşmasının geçersizliğine değinerek; tarafların SCC bünyesinde ICC tahkim kuralları uygulanarak bir tahkim yargılaması öngörmelerinin pratikte uygulanabilir olmadığını ve tahkim anlaşmasının uygulanamaz, dolayısıyla geçersiz olduğunu itirazlarına eklemiştir. Ardından son argüman olarak, tahkim anlaşması geçerli kabul edilse dahi, tahkim anlaşmasına taraf olmamaları nedeniyle, SCC’nin yetkili olmadığını ve yetkili kabul edilse dahi, SCC’nin ICC Tahkim Kurallarını uygulamak için gerekli organizasyon yapısının ve deneyiminin olmadığını iddia etmiştir.

Baldprim ise, Rus hukukuna göre Custom Office'in hükümet adına hareket ettiği ve bu nedenle Rusya Federasyonu Hükümeti’nin de sözleşme ile bağlı olacağı, tarafların SCC bünyesinde ICC tahkim

245 Schroeter (n 174) 181.

246 Schroeter (n 174) 181.

247 I.M. Baldprim S.R.L. vs. The Government of Russian Federation [2015] Svea Court Of Appeal, T 2454-14 <https://www. arbitration.sccinstitute.com/views/pages/getfile.ashx?portalId=89\&docId=2281406\&propId=1578 > Erişim Tarihi: 01.04.2020. 
kuralları ile yürütülmesini kararlaştırdıkları tahkim anlaşmasının geçersiz olmadığı savunmasında bulunmuştur.

Svea Temyiz Mahkemesi, tahkim anlaşmasında çelişen veya belirsiz bir ifade olduğunda, bu ifadenin yorumlanarak tahkim anlaşmasının uygulanması yoluna gidilmesi gerektiğini ifade ederek, genel yönelimlerinin tahkim yanlısı bir yaklaşım olduğunu ortaya koymuştur. Somut olay için de Temyiz mahkemesi, taraf iradelerinin, uyuşmazlığın SCC bünyesinde çözülmesi noktasında açık olduğunu ancak bununla birlikte, SCC’nin, ICC tahkim kurallarına uygun bir tahkimi yönetmek için gerekli organizasyon yapısından yoksun olduğunu ifade etmiştir. Mahkeme tahkim anlaşmasının bu açıdan tutarsız başka bir ifadeyle çelişkili sayılabileceğini belirterek, sorunun, 'SCC'nin, ICC tahkim kurallarına uygun bir tahkimi yönetmek için gerekli organizasyon yapısından yoksun olmasının anlaşmanın geçerliliği üzerinde ne gibi bir etkiye sahip olduğu' noktasında toplandığını da hükmüne eklemiştir.

Sonuç olarak, Temyiz mahkemesi; tahkim anlaşmasından taraflar arasındaki uyuşmazlıkların tahkim yoluyla çözümlenmesi ve bu tahkimin de SCC nezdinde Stockholm'de yapılması gerektiğinin anlaşıldığı kanaatine varmıştır. Tüm bu tartışmalar neticesinde, Temyiz mahkemesi, tahkim anlaşmasının uygulanabilir ve geçerli olduğuna hükmetmiştir.

Ayrıca ifade etmek gerekir ki, mahkeme, tahkim anlaşmasını geçerli kabul ederken, Singapur Yüksek Mahkemesi'nin Insigma Teknoloji Limited Şirketi v. Alstom Tekonoloji Limited șirketi kararındaki gibi, bu türden hibrit tahkim anlaşmalarının ad hoc nitelik taşıdığına ilişkin bir çıkarım yapmamışıı ${ }^{248}$.

\section{Avusturya Yüksek Mahkeme Kararı ${ }^{249}$}

21 Ağustos 2018 tarihinde Avusturya Yüksek Mahkemesi de, incelediğimiz tüm diğer ülke mahkemelerine paralel şekilde, 'Viyana Uluslararası Tahkim Merkezi (VIAC) bünyesinde ICC kuralları uygulanması' noktasında anlaşılan bir hibrit tahkim klozunun geçerliliği yönünde karar vermiştir. Taraflar arasındaki tahkim klozu "işbu sözleşmeye ilişkin ortaya çıkacak tüm anlaşmazlıklar ... ICC tahkim kuralları çerçevesinde tahkim yolu ile çözümlenecektir ... tahkim yargılaması VIAC bünyesinde, Viyana'da gerçekleştirilecektir” şeklinde düzenlenmiştir ${ }^{250}$.

248 Berger (n 191)18-19.

249 21.08.2018 karar tarihli 18OCg1/18y Karar no.lu <https://www.internationallawoffice.com/Newsletters/ Arbitration-ADR/Austria/Graf-Pitkowitz-Rechtsanwalte-GmbH/Supreme-Court-evaluates-hybrid-arbitrationagreement\#dec> Erişim Tarihi: 27.08.2020. <https://www.ris.bka.gv.at/Dokumente/Justiz/JJT_20180821_ OGH0002_018OCG00001_18Y0000_000/JJT_20180821_OGH0002_018OCG00001_18Y0000_000.pdf> Erişim Tarihi: 27.08.2020.

250 "Every dispute arising out of or in connection with this contract that cannot be solved amicably within 60 days shall be decided by an arbitral tribunal in accordance with the arbitration rules of the International Chamber of Commerce that were in force when this contract was signed. The tribunal shall consist of three arbitrators appointed according to these rules. The arbitral award shall be final and binding to the parties. The arbitral proceeding, including oral hearings and the issuance of the award shall take place at the Vienna International Court of Arbitration in Vienna, Austria." 
Taraflardan biri, tahkim mahkemesi kararının iptali talebi ile Avusturya Mahkemelerine başvurmuştur. Yüksek mahkemede görülen davada, davacı, tahkim anlaşmasının çelişkili ve belirsiz olması sebebiyle geçersiz olduğunu; tahkim anlaşmasının, tahkimin VIAC kurallarınca gerçekleştirilmesi şeklinde düzenlendiğini ancak kurulan tahkim mahkemesinde ICC hükümlerinin uygulandığı itirazında bulunmuştur.

Mahkeme, kararında, tahkim anlaşmasının çelişkili mi yoksa belirsiz mi olduğunu ele almış, neticeten, (1) tarafların uyuşmazliklarını tahkim yolu ile çözme noktasında anlaştı̆̆ı, (2) tahkim mahkemesinin üç hakemden oluşacağı ve ICC tahkim kuralları uyarınca oluşturulacağı, (3) yargilamanın VIAC bünyesinde gerçekleştirileceği kanaatine varmıştır. Mahkeme, "ICC Kurallarına göre bir tahkim mahkemesinin oluşturulması ve ardından davanın VIAC bünyesinde yürütülmesinin mümkün olması" nedeniyle çelişki iddialarının bertaraf edildiği kanaatindedir. "Belirsizlik" iddiaları noktasında ise, Mahkeme, belirsizliğin, yargılamanın ICC Kuralları uyarınca mı yoksa VIAC kuralları uyarınca mı yapılacağı noktasında toplandığını ancak tahkim kararının ICC kuralları uyarınca oluşturulacak bir hakem heyeti tarafından verilmesi gerektiğinin açık olduğunu ifade etmiştir. Avusturya Yüksek Mahkemesi bu belirsizliklerin yorum yolu ile çözülebilecek belirsizlikler olduğuna ve kararın iptalini gerektirecek bir belirsizlik bulunmadığına hükmetmiştir.

Görüldüğg̈ üzere diğer ülke mahkemeleri gibi Avusturya Yüksek Mahkemesi de hibrit tahkim anlaşmasının geçerliliğini kabul etmiştir. Avusturya Yüksek Mahkemesi de, tahkim iradesinin açık olduğu ve anlaşmada belirsizlik oluşturan noktaların, yorum yolu ile giderilebileceği kanaatindedir.

\section{TÜRK HUKUKU AÇISINDAN KURUMSAL BIR TAHKIM MERKEZININ BIR BAŞKA TAHKIM MERKEZININ KURALLARI ILE YETKILENDIRILDIĞi TAHKIM ANLAŞMALARININ GEÇERLILIĞi}

Yukarıda da ayrıntılı olarak incelendiği üzere, Türk hukukunda, tahkim anlaşmasının geçerliliğine uygulanacak hukuk; HMK’nın uygulama alanına giren iç tahkimde Türk hukuku ve HMK hükümleri iken, MTK’nın uygulama alanına giren ${ }^{251}$ yargılamalarda ise MTK m. 4’e göre, taraflar tahkim anlaşmasına uygulanmak üzere bir hukuk seçmişse bu hukuk, böyle bir hukuk seçimi yoksa Türk hukukudur.

Türk yargısı önünde görülecek bir tahkim kararının iptali davasında, tahkim anlaşmasının 'hibrit' nitelik göstermesi nedeniyle geçersiz olduğu iddiaları ileri sürüldüğünde, Türk mahkemeleri, tahkim anlaşmasının geçerliliğini, MTK m.4/f.3 kapsamında taraflarca tahkim anlaşmasının geçerliliğine uygulanmak üzere seçilmiş bir hukuk varsa bu hukuka göre, böyle bir hukuk seçimi yapılmamışsa Türk hukukuna göre değerlendirilecektir ${ }^{252}$.

251 MTK m.1/f.2 "Bu Kanun, yabancıllk unsuru taşıyan ve tahkim yerinin Türkiye olarak belirlendiği veya bu Kanun hükümlerinin taraflar ya da hakem veya hakem kurulunca seçildiği uyuşmazlklar hakkında uygulanır."

252 Sözleşmenin geçerliliğine uygulanacak hukuk hakkında ayrıntılı inceleme için bkz I/B. Tahkim Anlaşmasının Geçerliliğine Uygulanacak Hukuk. 
Türk hukukunda, iptal sebepleri kanunda sınırlı olarak sayılmışıı ${ }^{253}$. Bu sebepler arasında, tahkim anlaşmasının hibrit nitelikte olması sayılmaması nedeniyle; Türk hukukunda bir tahkim kararı, yalnızca hibrit nitelik taşıdığı gerekçesiyle iptal edilemeyecektir. Ancak, MTK m. 15/A/1 “(a)... tahkim anlaşmasının, tarafların anlaşmayı tabi kıldikları hukuka veya böyle bir hukuk seçimi yoksa Türk hukukuna göre geçersiz olması" hükmü ile, tahkim anlaşmasının geçersiz olmasını, kararın iptal nedenlerinden biri olarak saymıştır, dolayısıyla hibrit tahkim anlaşmalarının geçersizliği durumlarında, hakemlerce verilen kararlar iptal edilebilir hale gelebilecektir.

Kanaatimizce, Türk hukukunda, hibrit tahkim anlaşmalarını yasaklar nitelikte bir hüküm bulunmaması nedeniyle, tahkim iradesinin açı olduğu hibrit tahkim anlaşmaları, tatbik edilebilir ve geçerli kabul edilmelidir. Bir tahkim anlaşmasının hibrit nitelik göstermesi, iptal sebebi olarak kabul edilemez. Hatta denilebilir ki, MTK m. 15/A/1 hükmü gereğince "(f) Tahkim yargılamasının, usul açısından tarafların anlaşmalarına” uygun yürütülmemesi kararın iptali sebebi olarak sayıldığından, tarafların hibrit bir tahkim kararlaştırmaları durumunda, hakemlerin seçilen kurallara göre değil, kendi tahkim merkezi kurallarına göre karar vermeleri, tahkim anlaşmasının iptali sonucunu doğurabileceği gibi tenfizinin reddine de neden olabilir. Başka bir ifadeyle, tahkim anlaşmasının salt hibrit nitelik taşıması, verilen kararın iptalini veya tenfizinin reddini ${ }^{254}$ gerektirmeyecek, buna karşın hakemlerin hibrit tahkim yürütmeyerek tarafların seçtiği tahkim kurumunun kurallarını uygulamaması, kararın iptali veya tenfizinin reddi sonucunu doğurabilecektir.

Türkiye'de bir tahkim kurumu bünyesinde, ICC kuralları uygulanarak tahkim yargılaması yapılmasını öngören hibrit bir tahkim anlaşmasıyla karşılaştığımızda, Türk hukukuna göre, HMK ya da MTK hükümleri çerçevesinde hibrit tahkim anlaşmasının geçerliliği değerlendirildiğinde, kanaatimizce, Türk hukukunda hibrit tahkimi engeller nitelikte bir hüküm bulunmaması sebebiyle, hibrit tahkim anlaşmalarının geçerli kabul edilmesi gerekmektedir.

Bu tür hibrit tahkim anlaşmalarında, tarafların tahkim iradeleri açık ve kesindir. O halde, Türk hukukunda sıklıkla tahkim anlaşmalarını geçersiz kılan sebeplerden; "tahkim iradesinin açı ve kesin olmaması" hibrit tahkim anlaşmalarında geçersizlik sebebi olarak ileri sürülemeyecektir.

253 Akıncı, Milletlerarası Tahkim (n 3) 334 dn 451; Nomer (n 17) 588. MTK m. 15/A “... Hakem kararları aşağıdaki hallerde iptal edilebilir: 1. Başvuruyu yapan taraf; a) Tahkim anlaşmasının taraflarından birinin ehliyetsiz ya da tahkim anlaşmasının, tarafların anlaşmayı tabi kıldıkları hukuka veya böyle bir hukuk seçimi yoksa Türk hukukuna göre geçersiz olduğunu, b) Hakem veya hakem kurulunun seçiminde, tarafların anlaşmasında belirlenen veya bu Kanunda öngörülen usule uyulmadığın, c) Kararın, tahkim süresi içinde verilmediğini, d) Hakem veya hakem kurulunun, hukuka aykırı olarak yetkili veya yetkisiz olduğuna karar verdiğini, e) Hakem veya hakem kurulunun, tahkim anlaşmast dışında kalan bir konuda karar verdiğini veya istemin tamamı hakkında karar vermediğini ya da yetkisini astığını,f) Tahkim yargılamasının, usul açısından tarafların anlaşmalarına veya bu yönde bir anlaşma bulunmaması halinde, bu Kanun hükümlerine uygun olarak yürütülmediğini ve bu durumun kararın esasına etkili olduğunu, g) Taraflarm eşitliği ilkesinin gözetilmediğini, İspat ederse veya, 2. Bölge adliye mahkemesince; (1) a) Hakem veya hakem kurulu kararına konu uyuşmazlı̆̆ı Türk hukukuna göre tahkime elverişli olmadığı, b) Kararın kamu düzenine aykırı olduğu Tespit edilirse..."

254 Yabancı bir tahkim kararı tenfiz için Türk mahkemeleri önüne geldiğinde ise tahkim anlaşmasının geçerliliği Milletlerarası Özel Hukuk Ve Usul Hukuku Hakkında Kanun (MÖHUK) m. 62 f. 1 "Mahkeme ... (e) Tahkim sözleşmesi veya şartı taraflarca tâbi kılındığı kanuna, bu konuda bir anlaşma yoksa hakem hükmünün verildiği ülke hukukuna göre hükümsüz ise,... yabancı hakem kararının tenfizi istemini reddeder." hükmü nedeniyle, taraflarca geçerliliğe uygulanmak üzere seçilen hukuka, eğer bir hukuk seçilmemişse kararın verildiği hukuka göre geçerli olmaması durumunda tenfiz edilebilecektir. 
Kanaatimizce, hibrit tahkim anlaşmaları tahkim iradesindeki sakatlıklar nedeniyle değil ancak, 'tatbiki imkânsız' olması nedeniyle sakat hale gelebilir. Bu durum, genel bir kabul değil, somut olaylarda ayrıntılı olarak değerlendirilmesi gereken bir husustur.

Tahkimi yönetmesi için seçilen tahkim merkezi, diğer tahkim merkezinin tahkim kurallarını mutatis mutandis ilkesi çerçevesinde uyarlayarak uygulayabilir. Ancak istisnai durumlarda, tahkime uygulanması için seçilen tahkim merkezi kuralları, tahkimi yönetmesi için seçilen tahkim kurumu tarafından uygulanamaz nitelikteyse ya da tahkim kurumu bu kuralları uygulamayı kabul etmezse, tahkim anlaşmasında bir "icra edilemezlik" durumu meydana gelecektir. Peki bu türden "icra edilemezlik" tahkim anlaşmasını geçersiz kılacak mıdır? Zira, NYS m. II/f. $3^{255}$ hükmünde, tahkim itirazı neticesinde mahkemenin, tahkim anlaşmasının hükümden düşmüş, tesirsiz veya tatbiki imkânsız olup olmadığını değerlendirmesi gerektiği hükme bağlanmıştır. HMK m. 413 hükmünde de mahkemenin tahkim itirazı üzerine yapacağı incelemede "tahkim anlaşmasının hükümsüz, tesirsiz, uygulanması imkânsız" olup olmadı̆̆ının tespit edilmesi gerekmektedir. MTK m.5, "tahkim itirazının kabulü halinde, mahkeme davayı usulden reddeder" hükmünü havi olup, tahkim itirazı üzerine mahkemece yapılacak incelemede, "tahkim anlaşmasının hükümsüz, tesirsiz, uygulanması imkânsız" olup olmadığının incelenmesine ilişkin bir ifade bulunmamakla birlikte, doktrinde, mahkemenin tahkim itirazı üzerine yapacağı incelemede "tahkim anlaşmasının hükümsüz, tesirsiz, uygulanması imkânsız" olup olmadığının tespit edilmesi gerektiği ifade edilmektedir ${ }^{256}$. Bir anlamda burada tahkim anlaşmasının geçersiz olup olmadığı tespit edilmektedir. Yine, HMK "İptal davası" başlıklı m. 439 / (2) (a) hükmü ${ }^{257}$ ve "İptal davası ve hakem kararlarının icra edilebilir hâle gelmesi” başlıklı MTK m.15 (A) (1) (a) hükmünde ${ }^{258}$, tahkim anlaşmasının geçersiz olmasını bir iptal sebebi olarak öngörülmüştür. Diğer taraftan, hakem kararının tenfizi aşamasında da tahkim anlaşmasının geçersizliği tenfizin reddine sebep olmaktadır (NYS m. V/ 1 /a hükmü ${ }^{259}$ ve MÖHUK m.62/f.1 $\left.(\mathrm{e})^{260}\right)$.

255 Bu konuda açıklamalar için bkz. I, A, 2. Tahkim Anlaşmasının Geçersizliğinin Tahkim İlk İtirazı Neticesinde Devlet Mahkemesi Önünde İleri Sürülmesi.

256 Balkar Bozkurt (n 20) 198, 202.

257 HMK. m. 439, “(1) Hakem kararına karşı yalnızca iptal davası açılabilir. İptal davası, tahkim yeri bölge adliye mahkemesinde açlır; öncelikle ve ivedilikle görülür. (2) (a) Tahkim sözleşmesinin taraflarından birinin ehliyetsiz ya da tahkim sözleşmesinin geçersiz olduğu, b) Hakem veya hakem kurulunun seçiminde, sözleşmede belirlenen veya bu Kısımda öngörülen usule uyulmadığı, ..."

258 MTK. Madde 15 - "A) Hakem kararına karşı yalnızca iptal davası açılabilir. (Değişik ikinci cümle: 28/2/2018-7101/53 md.) İptal davası, 3 üncü madde uyarınca yetkili asliye hukuk mahkemesinin bulunduğu yer yönünden yetkili bölge adliye mahkemesinde açıllr, öncelikle ve ivedilikle görülür. Hakem kararları aşağıdaki hallerde iptal edilebilir: 1. Başvuruyu yapan taraf; a) Tahkim anlaşmasının taraflarından birinin ehliyetsiz ya da tahkim anlaşmasının, tarafların anlaşmayı tâbi kıldıkları hukuka veya böyle bir hukuk seçimi yoksa Türk hukukuna göre geçersiz olduğunu,..."

259 New York Sözleşmesi m. V/1/a - "Aleyhine hakem kararı dermeyan edilen tarafların talebi sekbetmez ve mumaileyh, kararın tanınması ve icrası istenen memleketin salahiyetli makamı huzurunda aşağıdaki hususları ispat etmez ise hakem kararının tanınması ve icrası talebi reddolunamaz; (a) II. maddede derpiş olunan anlaşmayı akdeden taraflar, haklarında tatbiki gereken kanuna göre ehliyetsiz olur yahut da mezkur anlaşma taraflarca tabi kilindığı kanuna ve bapta sarahat mevcut değilse hakem kararının verildiği mahal kanununa göre hükümsüz bulunur ise; veya..."

260 MÖHUK m. 62/f. 1 hükmü, "Mahkeme ... (e) Tahkim sözleşmesi veya şartı taraflarca tâbi kılındı̆̆ı kanuna, bu konuda bir anlaşma yoksa hakem hükmünün verildiği ülke hukukuna göre hükümsüz ise,... yabancı hakem kararının tenfizi istemini reddeder." 
O halde, tahkim anlaşmasının bu haliyle uygulanamaz olmasını, "icra edilemez bir tahkim anlaşması" olarak nitelendirmek, tahkim anlaşmasının geçersiz olduğu sonucunu beraberinde getirmektedir. Ancak, tahkim anlaşmasının bu haliyle uygulanamaz olmasından dolayı, böyle bir tahkim anlaşmasının geçersiz olduğu sonucuna varabilmek için, tahkim anlaşmasının tatbikinin imkânsız olması gerekir. Bu durumda böyle bir imkânsızlık söz konusu mudur? Tahkim anlaşmasının "uygulanmasının imkânsız" olduğunun tespitinde, başka bir ifadeyle, tahkim anlaşmasının geçersizliği sonucuna varılmasını gerektirecek derecede "icra edilemez" olduğunun tespitinde; tahkim anlaşmalarını mümkün olduğunca geçerli kılmaya yönelik yorum tercih edilmelidir. Böyle bir durumda, tahkim anlaşmasını tümden geçersiz kılmak yerine, icra edilebilir hale getirecek yorumlar yapılması yerinde olacaktır, zira tarafların tahkim iradesi tüm icra güçlüklerine karşın devam eder. Kanaatimizce, bu durumda, Türk hukukunda da, Singapur Yüksek mahkemesinin içtihatlarındaki gibi, seçilen kurumun tahkimi fiilen yönetecek kurum olarak dikkate alınarak, tarafların tahkim iradesi açık olduğundan, taraflarca kararlaştırılan tahkimin ad hoc tahkim olarak kabul edilmesi ve tarafların tahkim iradesinin bağlayıcılığının ayakta tutulması gerekmektedir. Zira, tahkimde önemli olan, tarafların tahkime yönelik iradesinin varlığı ile tahkim yargılamasına uygulanmak üzere taraflarca seçilen usul hukukunun bu tahkim yargılamasında uygulanmasıdır. Önerdiğgimiz bu çözüm, seçilen tahkim kurumuna değil, taraflarca seçilen usul hukukunun tahkim yargılamasında uygulanmasına üstünlük tanımaktadır. Zira, tahkim yargılaması neticesinde verilecek kararın iptali ya da tenfizinin reddine sebep olacak neden, seçilen kurumun tahkimi gerçekleştirmemesi değil, seçilen usul kurallarının uygulanmamasıdır.

Sonuç olarak, tarafların, tahkimin başkaca bir kurum ya da ad hoc şekilde ICC kuralları - ya da başka bir kurumsal tahkim merkezi kuralları - çerçevesinde yürütülmesini kararlaştırması durumunda, tahkim anlaşmasının geçersiz olduğu yönünde bir yorum yapmak, tahkimin taraf iradelerine üstünlük tanıyan yapısına ve tahkimi ayakta tutmaya yönelik yoruma ters düşecektir. $\mathrm{Bu}$ türden tahkim anlaşmalarının, tarafların tahkim iradeleri açıkken, tahkim anlaşmasının geçerliliği önünde bir engel teşkil edecek şekilde yorumlanmaması gerektiği kanaatindeyiz. Singapur Yüksek Mahkemesi’nin de belirttiği gibi, her ne kadar hibrit tahkim birçok sorun ve yargılama bakımından engeller taşısa da, tarafların tercihi bu yönde olduğunda, tahkim anlaşmasının esaslı unsurlarında belirlilik ve netlik olduğu kabul edilerek, anlaşma geçerli kabul edilmelidir.

\section{SONUÇ}

Birden fazla unsurun sentezlenerek oluşturulduğu tahkim anlaşmaları hibrit tahkim anlaşması olarak adlandırılmaktadır ve hibrit tahkim anlaşmalarının iki farklı görünüş biçimi bulunmaktadır: (1) İki farklı çözüm yoluna atıf yapılmak suretiyle kurulan tahkim anlaşmaları ve (2) bir tahkim merkezi ile birlikte farklı bir tahkim merkezi kurallarına atıf yapılmak suretiyle kurulan tahkim anlaşmaları.

İki farklı çözüm yolunun sentezi şeklinde, farklı çözüm yollarına birlikte atıf yapılarak kurulan tahkim anlaşmaları, tahkim anlaşması öncesi kademeli olarak diğer alternatif uyuşmazlık çözüm 
yöntemlerinin öngörülmüş olması şeklinde kurulabileceği gibi, devlet mahkemelerine başvurudan önce kademeli olarak tahkim yargılamasının öngörülmesi şeklinde de gerçekleştirilebilecektir.

Tahkim öncesi başkaca alternatif uyuşmazlık çözüm yollarına gidilmesini öngören kademeli hibrit tahkim anlaşmaları konusunda tartışmalı olan husus, tahkim öncesi başvurulması öngörülen aşama tüketilmeden tahkim yargılamasına gidilip gidilemeyeceği üzerinde toplanmıştır. Zira, tarafların böyle bir niyeti yoksa, tahkim anlaşmalarına bir başka alternatif uyuşmazlık çözüm yöntemini eklememeleri daha yerinde olacaktır. Ancak belirtmek gerekir ki, tahkim öncesi aşamaları tüketmemek, tahkim anlaşmasını geçersiz hale getirmez. Kanaatimizce tahkim öncesi aşamalar tüketilmeden tahkime gidilmesi durumunda, itiraz halinde tahkim mahkemesi bu durumu bekletici mesele yaparak aşamaların tamamlanmasını beklemeli, yargılamayı sonlandırmamalıdır. Tahkim öncesi aşamaların başarılı olması durumunda, artık ortada bir uyuşmazlık kalmaması nedeniyle dava konusuz kalacağından tahkim mahkemesi davayı reddetmeli; tahkim öncesi aşamalar başarısız olursa, yargilamaya devam etmelidir.

Devlet mahkemeleri ile birlikte tahkime başvuruyu öngören anlaşmalar, aslında, 'uyuşmazlı̆̆ın tahkimde çözümlenememesi halinde hangi devlet mahkemelerinde çözümleneceğini belirterek yetkili devlet mahkemesi belirlemesine yönelikse', bu anlaşma geçerli kabul edilebilir. Ancak tahkimin devlet yargısına alternatif özel bir yargılama usulü olması, tahkim neticesinde tarafları ve üçüncü kişileri bağlayıcı karar verilecek olması özellikleri göz ardı edilerek, tahkimin mahkeme öncesi başvurulacak bir uzlaşma makamı gibi belirlendiği tahkim anlaşmaları, hukuken bir tahkim anlaşması olmamakla birlikte, tahkim anlaşması olduğu kabul edilse dahi geçersiz bir anlaşma olacaktır.

ICC’nin kendi kuralları çerçevesinde başka bir tahkim kurumu bünyesinde tahkim yargılaması yapılmasını yasaklar nitelikte getirdiği kuralları neticesinde ortaya çıkan, bir tahkim merkezi ile birlikte, farklı bir tahkim merkezinin kurallarına atıf yapılan hibrit tahkim anlaşmalarının ise, incelediğimiz Singapur, Avusturya, İsveç, Amerika ve Çin mahkemeleri kararlarında da kabul edildiği üzere geçerli olduğu kanaatine varılmıştır. Her ne kadar, incelendiğinde, mahkemelerin sunduğu çözümler farklılık gösterse de, tahkim anlaşmalarını geçersiz kabul eden bir yaklaşımla karşılaşılmamaktadır.

Singapur Yüksek Mahkemesi Insigma Teknoloji v Alstom Teknoloji kararında, hibrit tahkimi bir ad hoc tahkim olarak kabul ettiği gibi, kanaatimizce, bir tahkim merkezi ile birlikte farklı bir tahkim merkezinin kurallarına atıf yapılan hibrit tahkim anlaşmalarının, Türk Hukuku açısından da ad hoc tahkim olarak kabul edilmesi daha yerinde olacaktır. Ancak, bu yönde genel bir kabul, ad hoc tahkimin mümkün olmadığı ülkeler bakımından tahkim anlaşmasının geçersizliği ve bu nedenle iptali ve hatta tenfizinin reddine neden olabilecektir. Bu hususlar dikkate alınarak, bu türden bir tahkimi genel bir kategoriyi koymak yerine, her devlet kendi hukukuna göre bir değerlendirme yapmalı ve tahkim anlaşmasının geçersizliğine neden olacak bir değerlendirme yapmaktan kaçınmalıdır.

Tarafların tahkimin başkaca bir kurum ya da ad hoc şekilde ICC kuralları - ya da başka bir kurumsal tahkim merkezi kuralları - çerçevesinde yürütülmesini kararlaştırması durumunda, tahkim 
anlaşmasının geçersiz olduğu yönünde bir yorum yapmak, tahkimin taraf iradelerine üstünlük tanıyan yapısına ve tahkimi ayakta tutmaya yönelik yoruma ters düşecektir. Bu türden tahkim anlaşmalarında, tarafların tahkim iradeleri açıkken, tahkim anlaşmasının geçerliliği önünde bir engel teşkil edecek şekilde yorumlanmaması gerektiği kanaatindeyiz. Singapur Yüksek Mahkemesi’nin de belirttiği gibi, her ne kadar hibrit tahkim birçok sorun ve yargılama bakımından engeller taşısa da, tarafların tercihi bu yönde olduğunda, tahkim anlaşmasının esaslı unsurlarında belirlilik ve netlik olduğu kabul edilerek, anlaşma geçerli kabul edilmelidir.

Hibrit bir tahkim anlaşmasının geçerliliği Türk hukukuna göre HMK ya da MTK hükümleri çerçevesinde değerlendirildiğinde; Türk hukukunda hibrit tahkimi engeller nitelikte bir hüküm bulunmaması sebebiyle ve tahkim iradesinin açık olması nedeniyle, kanaatimizce geçerli kabul edilmelidir.

\section{KAYNAKÇA}

Akıncı Z, Milletlerarası Tahkim (5th edn, Vedat 2020).

Akıncı Z, Milletlerarası Özel Hukukta İnşaat Sözleşmeleri (1st edn, Dokuz Eylül Üniversitesi, 1996).

Ay Chelli E, 'Fransız Yargıtay’ının Zorunlu Olmayan Uzlaşma Şartı Tüketilmeden Dava Açılabileceğine İlişkin 29 Nisan 2014 Tarihli Kararının Tercümesi' (2015) 4(2) UTTDER 233-237.

Aydemir F, Türk Hukukunda Tahkim Sözleşmesi (1st edn, On İki Levha 2017).

Aydın E, 'Milletlerarası Ticari Tahkimde Patolojik Tahkim Şartı ve Sözleşmesi' (LL.M. thesis, İstanbul Üniversitesi 2018).

Balkar Bozkurt Süheyla, 'Milletlerarası Tahkimde Yargılama Masraflarının Hak Arama Özgürlüğüne Etkisi ve Sonuçları' (Mayıs-Haziran 2015), 10 (129-130) Bahçeşehir Üniversitesi Hukuk Fakültesi Dergisi 121222.

Bayraktaroğlu Özçelik G, Milletlerarası Usul Hukukunda Paralel Davalar (1st edn, Yetkin 2016).

Berger KP, 'Institutional Arbitration: Harmony, Disharmony and the "Party Autonomy Paradox" (XI Conferencia Internacional Hugo Grocio de Arbitraje, Madrid 2018 ).

Blackaby N, Partasides C, Redfern A and Hunter M, Redfern and Hunter on International Arbitration Student Version (6th edn, Oxford 2015).

Comşa P, 'At A Crossroads: The Case of "Pathological Arbitration Clauses" Which Determine A Jurisdictional Fight’ (2018) 25(2) Lex ET Scientia International Journal 47-55.

Coulson R, 'MEDALOA: A Practical Technique for Resolving International Business Disputes' (1994) 11(2) Journal of International Arbitration, 111-113.

Çelikel A and Erdem BB, Milletlerarası Özel Hukuk (15th edn, Beta 2017).

Davis BG, 'Pathological Clauses: Frederic Eisemann's Still Vital Criteria' (1991) 7(4) Arbitration International 365-388.

Demir Gökyayla C, 'Arabuluculuk ve Tahkimi Bir Arada İçeren Uyuşmazlık Çözüm Yolu’ (2019) 77 (2) İstanbul Hukuk Mecmuası 575-616.

Demirkol B and Aküzüm U, Türkiye'de Med-Arb (Arabuluculuk-Tahkim) Yapısı, Mevzuatı \& Uygulaması (1st edn, On İki Levha 2020).

Demirkol B, 'Mutlak Olmayan Milletlerarası Tahkim Anlaşmalarının Geçerliliği' (2017) 16(2) GSÜHFD 325254. 
Doğan V, Milletlerarası Özel Hukuk (5th edn, Savaş 2019).

Draguiev D, 'Unilateral Jurisdiction Clauses: The Case for Invalidity, Severability or Enforceability' (2014) 31(1) Journal of International Arbitration 19-46.

Eisemann F, 'La clause d'arbitrage pathologique" l'arbitrage international' (1974), C.3 Arbitrage commercial/ Commercial Arbitration, Essais in memoriam Eugenio Minoli, 129-161.

Ekşi N, Hukuk Muhakemeleri Kanunu’nda Tahkim (2nd edn, Beta 2019).

Ekşi N, Tahkim Öncesi Uyuşmazlık Çözüm Usulleri ve Bu Usuller Tüketilmeden Tahkime Başvurulmasının Sonuçları (1st edn, Beta 2015).

Ekşi N, "Milletlerarası Tahkimde Paralel Davalar (Parallel Litigation)” (2013) 2 (2) UTTDER 15-51.

Erkan M, Milletlerarası Tahkimde Yetki Sorunları (1st edn, Yetkin 2013).

Erlank W, Enforcement of Multi-Tiered Dispute Resolution Clauses (SSRN, 9 September 2002 2002) <https:// papers.ssrn.com/sol3/papers.cfm?abstract_id=1491027> Erişim tarihi 5 June 2020.

Ertekin E and Karataş İ, Uygulamada İhtiyari Tahkim ve Yabancı Hakem Kararlarının Tenfizi Tanınması (1st edn, Yetkin 1997).

Esen E, 'Uluslararası Tahkime Tâbi Bir Uyuşmazlığın Devlet Mahkemelerine Götürülmesi Halinde Tahkim Anlaşmasının Geçerliliğine İlişkin İtirazların İncelenmesi ve Kompetenz-Kompetenz Prensibi' (2011) 10(1) GSÜHFD Prof. Dr. Ata Sakmar’a Armağan 355-380.

Esen E, 'Yetkili Kılınan Tahkim Kurumunun Mevcut veya Belirli Olmadığı Tahkim Anlaşmalarının Geçerliliğı' (2017) 2017(2)UTTDER 75-148.

Esen E, 'Yabancı Mahkeme Lehine Yapılan Yetki Anlaşmasına Dayanan Yetki İtirazının Değerlendirilmesinde Dürüstlük Kuralının Etkisi ve Yargıtay 11. Hukuk Dairesinin 6.3.2009 tarihli İçtihadının Eleştirisi’ (2011) 31 (1) MHB 191-207.

Fouchard P, Gaillard E and Goldman B, Traité de l'arbitrage commercial international (Litec 1996).

Fry J, 'HKL Group Ltd. v. Rizq International Holdings Pte. Ltd. and HKL Group Co. Ltd. v. Rizq International Holdings Pte. Ltd.' (2013) 30(4) Journal of International Arbitration 453-462.

Gedik B, Milletlerarası Tahkim Kararlarının İptal Edilme Nedenlerinden Tahkim Anlaşmasının Geçersiz Olması (1st edn, Seçkin 2020).

Henriques DG, 'Pathological Arbitration Clauses, Good Faith and The Protection of Legitimate Expectations' (2015) 31(2) Arbitration International 349-362.

Ildır G, Alternatif Uyuşmazlık Çözümü-Medeni Yargıya Alternatif Yöntemler (1st edn, Seçkin 2003).

Işık F, Milletlerarası Ticari Tahkimde Tahkim Anlaşması Yapma Yetkisi ve bu Yetkiye Uygulanacak Hukuk (1st edn, On İki Levha 2015).

İlhan HA, Tahkim Sözleşmesinin Geçerliliği (1st edn, Adalet 2016).

Jain A, 'Pathological Arbitration Clauses and Indian Courts' (2008) 25(4) Journal of International Arbitration 433-448.

Kayalı D, 'Enforceability of Multi-Tired Dispute Resolution Dispute Clauses' (2010) 27(6) Journal of International Arbitration 551-577.

Kaufmann-Kohler G and Rigozzi A, Arbitrage international, Droit et pratique à la lumière de la LDIP (1st edn, Editions Weblaw 2006)).

Molfa M, 'Pathological Arbitration Clauses and The Conflict of Laws' (2007) 37(1) Hong Kong Law Journal 161-184.

Moses ML, The Principles and Practice of International Commercial Arbitration (2nd edn, Cambridge 2012). 
Nicholls AC and Bloch C, 'ICC Hybrid Arbitrations Here to Stay: Singapore Courts' Treatment of ICC Rules Revisions in Articles 1(2) and 6(2)' (2014) 31(3) Journal of International Arbitration 393-412.

Nomer E, Devletler Hususi Hukuku (22nd edn, Beta 2017).

Oghigian H, 'The Mediation/Arbitration Hybrid' (2003), 20(1) Journal of International Arbitration 75-80.

Özbek M, Alternatif Uyuşmazlık Çözümü ( 3rd edn, Yetkin 2013).

Özdemir Kocasakal H, 'Yargıtay 15.Hukuk Daire’sinin Bir Kararı Çerçevesinde Mahkemelere De Yetki Veren Tahkim Anlaşmalarının Geçerliliği ve Bu Geçerliliğin Tespitinin Mahkemeler Tarafından Yapılıp Yapılamayacağı' (2017) On İki Levha Prof.Dr. Hamdi Yasaman’a Armağan, 509-535.

Özdemir Kocasakal H, 'Tahkim Şartı ile İlgili İptal Sebepleri' (2014) ICC Türkiye Yayını, XI. Milletlerarası Tahkim Semineri, 14 Nisan 2014, Ankara, 37-84.

Özdemir Kayalı D, 'Uluslararası Ticari Sözleşmelerde Basamaklı Uyuşmazlık Çözüm Şartları' (2009) Haluk Konuralp’in Anısına Armağan C. I, 499-515.

Özel S, Milletlerarası Ticari Tahkimde Kanunlar İhtilafı Kuralları (1st edn, Legal 2008).

Park WW, 'Arbitration of International Contract Disputes' (1984) 39(4) The Business Lawyer 1783-1799.

Pekcanıtez H and Yeşilırmak A, Pekcantez Usul Medeni Usul Hukuku C III (15th edn, On İki Levha 2017).

Qian J and Guo L, 'The Validity and Remedy of the Pathological International Commercial Arbitration Agreement' (2019), 2(5) International Law School of Northwest University of Political Science and Law 109-119.

Pisacane G, Murphy L and Zhang C, Arbitration in China - Rules \& Perspectives (1st edn, Springer 2016).

Rogers J, Lijun C and Townsend M, 'Legality of 'Hybrid' Arbitration Clauses Upheld in China' (2014), 6(3) Asian Dispute Review 146-149.

Ross HW and Conlon DE, 'Hybrid of Third-Party Dispute Resolution: Theoretical Implications of Combining Mediation and Arbitration' (2000), 25(2) The Academy of Management Review 416-427.

Rubino Sammartano M, International Arbitration Law and Practice (2nd edn, Kluwer Law International 2001).

Samra HJ and Ramachanderan R, 'A Cure for Every Ill? Remedies for “Pathological” Arbitration Clauses' (2020) 74(4) University of Miami Law Review 1110-1123.

Sarı̈z Büyükalp A İ, 'Uluslararası Tahkimde “Tahkim Anlaşmasının Hükümsüz, Tesirsiz veya İcrasının İmkânsız Olması” Kavramları' (2014), 16 (Özel Sayı) DEUHFD in Prof. Dr. Hakan Pekcanıtez’e Armağan 20152061.

Sarı̈̈z Büyükalp Aİ, Milletlerarası Ticari Tahkimde Tahkim İtirazı ile Karşılaşan Türk Hâkiminin Tahkim Anlaşmasının Geçerliliğine Dair Yapacağı İncelemenin Kapsamı ve Sonuçları (Eylül Ekim 2014) 9 (121122) Bahçeşehir Üniversitesi Hukuk Fakültesi Dergisi, 195-224.

Sato Y, 'Hybrid Dispute Processing in Japan: Linking Arbitration with Conciliation' Vijay K. Bhatia, Christopher N. Candlin, Jan Engberg and Jane Lung (eds), Legal Discourse across Cultures and Systems (Kluwer Academic 2008).

Schroeter UG, 'Ad Hoc or Institutional Arbitration - A Clear-Cut Distinction? A Closer Look at Borderline Cases' (2017) 10(2) Contemporary Asia Arbitration Journal 141-199.

Şanlı C, Esen E and Ataman Figanmeşe İ, Milletlerarası Özel Hukuk (8th edn, Beta 2020).

Şanlı C, Uluslararası Ticari Akitlerin Hazırlanması ve Uyuşmazlıkların Çözüm Yolları (7th edn, Beta 2019).

Şensöz E, Milletlerarası Tahkim Kanunu’nda Hakem Kararlarına Karşı Başvuru Yolları, Hakem Kararlarının İptali, (L.L.M. thesis Galatasaray Üniversitesi 2005).

Şit B, Kurumsal Tahkim ve Hakem Kararlarının Tanınması ve Tenfizi (1st edn, İmaj 2005). 
Tan Dehmen M, Tahkim Öncesi Müzakere Ya Da Uzlaştırma Yollarının Tüketilmiş Olmasının Tahkim Yargilamasina Etkisi (2011) 25(1-2) PPIL 451-472.

Tekin ES, Milletlerarası Tahkim Hukukunda Tahkim Anlaşmasının Geçerliliğe Uygulanacak Hukuk, (1st edn, On İki Levha 2019).

Tolkušinas K, 'Defective Arbitration Clauses in International Commercial Contracts' (Mater Thesis, Mykolas Romeris University 2010).

Töre N, Milletlerarası Tahkimde Tahkim Anlaşmasının Varlığı Geçerliliği ve Etkileri (1st edn, Turhan 2019).

Tweeddale A and Tweeddale K, Arbitration of Commercial Disputes International and English Law and Practice (1st edn, Oxford University Press 2005).

Willems J, Chapter 38: The Arbitrator's Jurisdiction at Risk: The Case of Hybrid and Asymmetrical Arbitration Agreements in Pierre A. Karrer, Patricia Shaughnessy, Sherlin Tung (eds), The Powers and Duties of an Arbitrator, Liber Amicorum Pierre A. Karrer (Kluwer Law International BV 2017).

Yener Keskin C, Milletlerarası Tahkim Anlaşmasının Kurulması ve Etkisi, (1st edn, On İki Levha 2017).

Yeşilırmak A, 'Geçerli Bir Tahkim Anlaşmasının Varlığına Rağmen Genel Haciz Yoluyla Takip Yapılabilir mi?’ (2011) 96 Türkiye Barolar Birliği Dergisi 205-228.

Yeşilırmak A, ICC Tahkim Kuralları ve Uygulaması (1st edn, On İki Levha 2018).

Yeşilova B, 'Milletlerarası Tahkimin Hukuki Niteliği Üzerine Düşünceler ve Güncel Gelişmeler' (2008), 76 Türkiye Barolar Birliği Dergisi 83-164.

Yeşilova B, Milletlerarası Ticari Tahkimde Nihai Karardan Önce Mahkemelerin Yardımı ve Denetimi (1st edn, Güncel 2008).

Yılmaz B, 'İsviçre Federal Mahkemesi’nin Tahkim Öncesi Alternatif Uyuşmazlık Çözüm Klozu’nun Bağlayıcılığı Konusundaki 7 Temmuz 2014 Tarihli Kararının Tercümesi' (2015) 4(2) UTTDER 261-284.

Yudistiana F, 'The Extent to Which Hybrid Arbitration Clauses Apply To Advance Investor-State Arbitration In The International Centre For Settlement Of Investment Disputes (ICSID)' (LLM thesis, Kingston University London 2015).

Milletlerarası Tahkim Konusunda Yasal Bir Düzenleme Gerekir Mi? II. Tahkim Haftası, Sempozyum-BildirilerTartışmalar, 11 Nisan 1997”, Ankara 1997. 